\title{
Kriteria dan Indikator Kelestarian Hutan yang Dikelola oleh Masyarakat (Community Managed Forest)
}

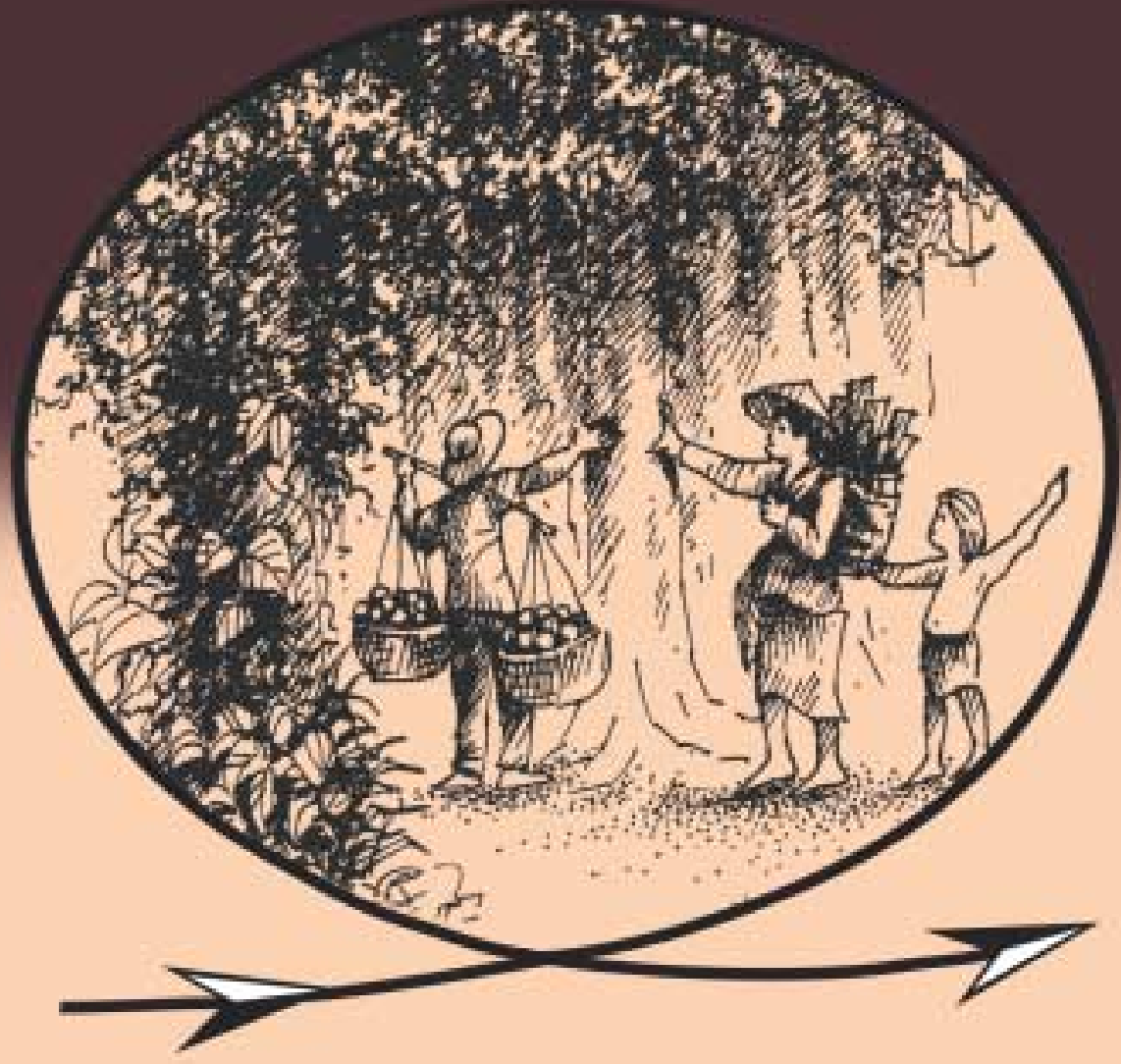

Bill Ritchie

Cynthia McDougall

Mandy Haggith

Nicolette Burford de Oliveira 


\title{
Pedoman Pendahuluan: Kriteria dan Indikator Kelestarian Hutan yang Dikelola oleh Masyarakat (Community Managed Forest)
}

\author{
Bill Ritchie \\ Cynthia McDougall \\ Mandy Haggith
}

Nicolette Burford de Oliveira

(C)2001 oleh Center for International Forestry Research

Dicetak oleh SMT Grafika Desa Putera, Indonesia

Ilustrasi: April Mansyah

Alih bahasa: Titiek Setyawati

Dukungan Editorial: E. Linda Yuliani

\section{ISBN 979-8764-51-X}

Diterbitkan oleh

Center for International Forestry Research

P.O. Box 6596 JKPWB, Jakarta 10065, Indonesia

Tel.: +62 (251) 622622; Fax: +62 (251) 622100

E-mail: cifor@cgiar.org

Website: http://www.cifor.cgiar.org

Dengan dukungan dari:

The International Development Research Centre (IDRC)

Asian Development Bank (ADB)

The Ford Foundation (FF)

The MacArthur Foundation (MAF)

The European Union (EU)

The Swiss Development Corporation (SDC)

United States Agency for International Development (USAID) 


\section{Daftar Isi}

Prakata vi

Ucapan terima kasih viii

$\begin{array}{ll}\text { Pendahuluan } & 1\end{array}$

Siapa yang harus membaca pedoman ini? 3

Kerangka 3

1. Pengelolaan Hutan oleh Masyarakat (PHM) 5

1.1 Mengapa pengelolaan hutan oleh masyarakat penting 5

1.2 Apa yang dapat membantu agar PHM berjalan baik? $\quad 7$

1.3 Apakah tantangan yang dihadapi PHM saat ini? 8

1.4 Penyesuaian terhadap perubahan 9

1.5 Penyesuaian terhadap berubahnya kemitraan 10

1.6 Bagaimana K\&l dapat membantu 11

2. Apakah Kriteria dan Indicator (K\&)? 13

2.1 Menetapkan K\&l 14

2.2 Contoh K\&l 15

3. Mengembangkan dan Menggunakan Perangkat K\&l 19

3.1 Latar Belakang: Ringkasan penelitian K\&l CIFOR 19

3.2 Persiapan untuk mengembangkan dan menggunakan K\&l: Pertanyaan yang harus diajukan sebelum Anda memulai 22

3.3 Penentuan stakeholder: Siapa yang perlu untuk $\begin{array}{ll}\text { dilibatkan? } & 27\end{array}$

3.4 Titik awal K\&l: Perangkat dasar, standar atau visi? 28

3.5 Mengembangkan K\&l: Beberapa langkah praktis 31

3.6 'Menyaring' K\&l: Apakah masing-masing merupakan yang terbaik untuk dikerjakan? $\quad 37$

3.7 Uji pertama: Melaksanakan penaksiran K\&l secara cepat 38

3.8 Pemantauan: Pelaksanaan K\&l di lapangan 40 
Prinsip 1. Kesejahteraan masyarakat terjamin 54

1.a Lembaga/organisasi masyarakat dan partisipasi 55

1.b Mekanisme pengelolaan lokal (norma, aturan, undang-undang, dll.) $\quad 57$

1.c Manajemen konflik 59

1.d Kewenangan untuk pengelola (status kepemilikan lahan) 60

Prinsip 2. Kesejahteraan rakyat terjamin 62

2.a Kesehatan dan makanan 62

2.b Kesejahteraan (mata pencaharian, pembagian biaya dan manfaat, kesetaraan) $\quad 64$

2.c Kebijaksanaan dan saling berbagi ilmu pengetahuan 66

2.d Kesepakatan status kepemilikan lahan dalam masyarakat 68

Prinsip 3. Kesehatan hutan terjamin 71

3.a Perencanaan (zonasi dan kawasan perlindungan) 72

3.b Pengelolaan fungsi ekosistem (daratan, air dan api) 73

3.c Intervensi produktif 1 (pertanian dan agroforestry) 76

3.d Intervensi produktif 2 (HHBK berupa tumbuhan) 79

3.e Intervensi produktif 3 (HHBK berupa satwa) 81

3.f Intervensi produktif 4 (kayu) 82

3.g Kesehatan hutan 1 (keanekaragaman hayati) 83

3.h Kesehatan hutan 2 (struktur dan regenerasi) 85

3.i Keanekaragaman bentang alam (fragmentasi dan mosaik) 87

Prinsip 4. Lingkungan eksternal mendukung PHML 90

4.a Hubungan dengan pihak ketiga 90

4.b Kebijakan dan kerangka hukum (tidak termasuk status

4.c Ekonomi 94

4.d Pendidikan dan informasi 95 
$\begin{array}{ll}\text { Permohonan tanggapan (umpan balik) } & 97\end{array}$

$\begin{array}{ll}\text { Bahan Acuan } & 98\end{array}$

Beberapa alamat penting yang berkaitan dengan PHM 103

Lampiran 1. Sinopsis permasalahan dan perbandingan antara lokasi uji K\&I PHM CIFOR 105

Lampiran 2. Perangkat dasar dan pedoman yang digunakan oleh tim penguji K\&I PHM 


\section{Prakata}

Pedoman ini dibuat sebagai sumbangan bagi upaya yang lebih luas di seluruh dunia yang bertujuan memperbaiki pengelolaan hutan, kesejahteraan manusia, dan kelestarian sumber daya alam. Agar semuanya dapat terlaksana, ada tiga (3) hal penting yang harus dicatat oleh siapapun yang bermaksud menggunakan pedoman ini:

1) Sama seperti alat bantu lainnya, semua yang ada dalam pedoman ini perlu dipertimbangkan, dan disesuaikan dengan kondisi/konteks lokasi tempat pedoman akan digunakan. Kami menganggap ini bukanlah suatu "blueprint" melainkan sebuah "batu loncatan" untuk kegiatan yang sesuai ...

2) Keberhasilan penerapan pendekatan yang disarankan dalam pedoman ini tergantung pada cukup tidaknya pemahaman menyangkut komitmen serta keahlian dalam melaksanakan proses dan pendekatan partisipatif. Ini tidak berarti bahwa hanya "praktisi profesional yang berpartisipasi" saja yang bisa menggunakannya. Lebih luas lagi dapat diartikan bahwa jika terjadi kekurangan dari salah satu atau seluruh pemahaman tersebut maka kesenjangan ini sebaiknya dibicarakan sebelum dan selama proses K\&l berlangsung (contohnya, melalui bacaan atau menghubungi alamat yang disebutkan dalam Bahan Acuan pada pedoman ini).

Selanjutnya, dalam kaitan dengan perihal 1 di atas, jika pendekatan kepada K\&I PHM dan proses untuk pemantauannya disesuaikan untuk penggunaan lokal, maka perlu sekali diperhatikan bahwa penyesuaian/adaptasi tersebut hendaknya meningkatkan dan memaksimalkan kesempatan untuk saling belajar dan rasa memiliki terhadap proses yang akan berlangsung. Contohnya, pedoman ini menyampaikan beberapa ide untuk membuat "struktur K\&l PHM", tetapi tidak terlalu jauh melangkah untuk menetapkan macam alat bantu partisipatif terbaik yang dapat digunakan oleh berbagai kelompok yang berbeda. Kami menghimbau para pengguna yang menerapkan pedoman ini agar memasukkan alat bantu partisipatif dan adaptasi yang 
mungkin diperlukan dalam setiap konteks. Kami juga mengantisipasi bahwa pada seluruh konteks, hal ini akan mencakup berbagai adaptasi seperti:

- sebuah permainan yang secara lokal sesuai untuk memperkenalkan ide

- perubahan dari kalimat tertulis menjadi penyajian berupa gambar atau kegiatan lain yang mudah dipahami sesuai kemampuan baca/tulis

- mengembangkan strategi untuk menyelesaikan masalah adanya hambatan dalam berpartisipasi (seperti gender, kasta, dan lainnya)

3) Kegiatan/pekerjaan ini masih berlangsung! CIFOR dan mitra kerjasamanya tetap melanjutkan kegiatan di bidang ini, dan kami sangat mengharapkan adanya masukan dan umpan balik/tanggapan menyangkut pedoman ini. 


\section{Ucapan Terima Kasih}

Buku pedoman ini merupakan hasil upaya keras dan sungguh-sungguh yang dikerjakan oleh banyak orang selama lebih dari beberapa tahun. Kami mengucapkan penghargaan yang tak terhingga kepada anggota masyarakat Akak/Bitele dan Eyek II (Propinsi Tengah, Kamerun), Cachoeira do Maro dan Sao Pedro (Para, Brazil) dan Bedigong dan Darok (Kalimantan Barat, Indonesia) atas partisipasinya dalam uji lapangan K\&l PHM CIFOR. Tanpa kerjasama yang baik dan partisipasi mereka, publikasi ini tidak mungkin terlaksana. Kami juga mengucapkan terima kasih dan penghargaan yang besar atas hasil kerja anggota tim antardisiplin ilmu, fasilitator, dan pendukung yang terlibat dalam kegiatan penelitian - secara khusus banyak sekali yang terlibat di dalamnya yang tidak mungkin disebutkan disini, tetapi sumbangan yang telah diberikan sangatlah berharga. Tidak lupa kami juga mengucapkan terima kasih kepada beberapa lembaga yang mempunyai andil dalam kerjasama ini antara lain: Proyek Kerjasama GTZ-Dephut/Indonesia untuk Social Forestry Development Project (SFDP) (Sanggau, Kalimantan); FERDA (Bogor, Indonesia); ONADEF (Kamerun); WWF-Kamerun; the Sindicato dos Trabalhadores Rurais de Santarem (STRSantarem), dan Projecto Saude e Alegria, Santarem, Brazil.

Kepada rekan-rekan peneliti di CIFOR yang telah banyak mendukung dan memberikan kritik dan komentarnya yaitu Dr. Ravi Prabhu, Dr. Godwin Kowero dan Dr. Michael Spilsbury. Juga kepada Yvonne Byron atas bantuan editorialnya, Gideon Suharyanto atas kreativitasnya dalam merancang tata letak laporan serta Rahayu Koesnadi yang tiada hentinya membantu dalam penyelesaian tulisan ini.

Terakhir, tidak lupa pula kami ucapkan terima kasih kepada lembaga-lembaga penyandang dana dalam pembuatan buku pedoman ini - International Development Research Centre (IDRC), Asian Development Bank (ADB), Ford Foundation dan MacArthur Foundation - demikian pula kepada European Union (EU), Swiss Development Corporation (SDC), dan USAID atas dukungannya dalam mempublikasikan hasil penelitian K\&I PHM. Kami tidak hanya berterima 
kasih atas sumber-sumber yang telah diberikan selama kajian tetapi juga atas dukungan, kebaikan dan kesabaran mereka yang telah banyak membantu dalam penulisan buku pedoman ini. 


\section{Pendahuluan}

Untuk menanggapi perubahan yang terjadi secara cepat dan kompleks di lingkungan hutan yang dikelola oleh masyarakat, CIFOR melaksanakan program penelitian pengembangan dan pengujian Kriteria dan Indikator (K\&l) untuk menilai kelestarian Pengelolaan Hutan oleh Masyarakat (PHM). ${ }^{1}$ Sebagai bagian dari Proyek CIFOR 'Assessing the Sustainability of Forest Management', maka tiga pengujian telah dilaksanakan di Brazil, Indonesia, dan Kamerun. Penelitian ini dilakukan berdasarkan penelusuran dan pemahaman peran $K \& l$ secara lebih mendalam di dalam pengelolaan hutan yang bersifat kerjasama dan adaptif yang dilakukan oleh masyarakat dan pihak terkait lainnya.

Pedoman ini ditulis berdasarkan hasil penelitian K\&I PHM CIFOR yang telah dilakukan selama ini, ${ }^{2}$ dan memuat saran-saran yang dapat diterapkan secara lebih praktis serta dikembangkan lebih jauh lagi di tingkat masyarakat. Berdasarkan pengalaman di tiga lokasi pengujian CIFOR, kami menyajikan K\&l sebagai alat bantu dalam pengelolaan hutan oleh masyarakat secara lestari (contohnya, hutan yang dikelola oleh masyarakat dimana aliran barang dan jasa dari hutan dapat dipertahankan tanpa mengurangi kualitas atau nilai untuk generasi yang akan datang). Tujuan pembuatan buku pedoman ini adalah untuk membantu para pengelola hutan yang berbasis masyarakat dan/atau praktisi dan mitranya untuk mengembangkan perangkat K\&l yang mudah dimengerti dan dipahami yang dibangun atas dasar ilmu pengetahuan

\footnotetext{
${ }^{1}$ Kami menggunakan istilah "Community management of forest" atau "Community managed forests (CMF)" daripada "Community forest management" (CFM), untuk menjaga agar cakupan referensi cukup luas. Sementara kami melibatkan areal yang ada di bawah pengelolaan oleh masyarakat secara ekslusif, kami juga mengacu pada areal yang dikelola sebagian oleh masyarakat (termasuk kerja sama atau pengelolaan bersama oleh masyarakat dan stakeholder) juga dimasukkan dalam hutan yang dikelola oleh masyarakat. Pengelolaan hutan oleh para stakeholder merupakan tantangan bagi kami untuk terus diteliti. Kami juga merencanakan lanjutan penelitian dan komunikasi tentang hal tersebut dengan pihak lain dan berharap dapat diterbitkan pada masa yang akan datang.
}

2 Burford de oliveira (1999) and Burford de Oliviera et al. (1999). 
bersama dan praktek yang dilakukan dengan baik. Perangkat K\&l selanjutnya dapat digunakan sebagai kerangka kerja untuk melakukan penilaian dan pemantauan terhadap terjadinya perubahan-perubahan yang pokok, memberikan informasi dan mempelajarinya kembali ke dalam sistem pengelolaan hutan oleh masyarakat, dan kemudian membimbing langkah selanjutnya menuju kelestarian.

K\&l dapat membantu masyarakat untuk:

- merancang tujuan pengelolaan hutan lestari;

- memantau kinerja mereka;

- menilai informasi penting yang dikumpulkan dari penerapan K\&;

- belajar dari informasi yang dikumpulkan;

- menyesuaikan sistem pengelolaan mereka terhadap perubahan yang terjadi;

- membuat keputusan yang lebih baik menyangkut langkah di kemudian hari; dan

- berkomunikasi secara efektif tentang dampak faktor eksternal termasuk kebijakan hutan.

Pedoman ini merupakan ringkasan pengalaman kami dan memberikan usulan sebuah pilihan yang dapat diadopsi oleh para praktrisi dan pengelola PHM. Meskipun sejauh ini kami belajar banyak dari pelaksanaan uji lapangan dan analisa, namun sampai saat ini masih dalam tahap penelitian dan yang lebih penting bagi kami adalah sebuah proses belajar. Kami mendorong masyarakat untuk mengadakan penyesuaian pedoman ini sedemikian rupa sehingga dapat diterapkan di lingkungan mereka dan kami dengan senang hati menerima umpan balik atau tanggapan terutama pengalaman yang diperoleh dari penerapan K\&I PHM. 


\section{Siapa yang harus membaca pedoman ini?}

Pedoman ini ditujukan kepada mereka yang ingin mengembangkan dan menggunakan $\mathrm{K} \&$ l sebagai alat bantu untuk memperbaiki sistem pengelolaan hutan oleh masyarakat. Pengguna potensial tersebut antara lain:

- tenaga penyuluh, pengembang proyek dan staf lembaga swadaya masyarakat (LSM) yang terlibat dalam kegiatan PHM beserta penduduk lokal atau di kawasan yang berpotensi untuk PHM;

- petugas departemen kehutanan yang bekerja dengan kelompok masyarakat dalam pengelolaan hutan atau pengelolaan hutan bersama oleh masyarakat; dan

- masyarakat yang termotivasi dengan sendirinya, danterorganisasi dengan kuat yang terlibat secara aktif dalam PHM, dan tidak hanya, mereka yang tertarik dalam sertifikasi.

\section{Kerangka}

Bagian 1 menyoroti pentingnya pengelolaan hutan oleh masyarakat, dan mengidentifikasi beberapa elemen kunci untuk mencapai keberhasilan, beserta tantangannya. Bagian ini menekankan pula pentingnya proses belajar bersama antara lain dalam pengelolaan dan komunikasi dua arah di antara masyarakat dan pihak terkait lainnya dalam kesepakatan pengelolaan yang saling bekerjasama, dan mengindikasikan kegunaan potensial dari K\&l.

Bagian 2 menerangkan tentang K\&l. Bagian ini juga menunjukkan bagaimana kebijaksanaan, ilmu pengetahuan dan informasi tentang pengelolaan hutan lestari dapat disusun dalam sebuah hirarki prinsip, kriteria, indikator dan penguji.

Bagian 3 menyarankan sebuah pendekatan ke arah pengembangan partisipatif perangkat lokal K\&l untuk Pengelolaan Hutan oleh Masyarakat secara Lestari (PHML). Bab ini tidak memberikan instruksi langkah demi langkah melainkan pedoman dan rekomendasi menyangkut prinsip 
pokok dari pelajaran yang diambil dari kegiatan di CIFOR. Selanjutnya memberikan suatu kerangka kemungkinan pendekatan untuk menerapkan perangkat $\mathrm{K} \& \mathrm{l}$ yang disepakati sebagai alat untuk melakukan pemantauan, penilaian dan evaluasi terhadap pengelolaan hutan dengan cara yang iteratif menuju pengelolaan yang lestari.

Bagian 4 mencakup isi dari K\&l untuk PHM. Ruang lingkup secara luas dari bagian isi yang relevan digambarkan melalui contoh-contoh $\mathrm{K} \& \mathrm{l}$ yang diperoleh dari tiga lokasi pengujian CIFOR. Ini dapat digunakan sebagai titik awal yang mungkin dilakukan untuk mengembangkan K\&l yang sesuai dengan lingkungan setempat.

Untuk yang terakhir, kami memberikan beberapa acuan kunci untuk beberapa dokumen dan pedoman pendukung yang berguna (tersedia cumacuma), termasuk laporan lengkap CIFOR berisi uji K\&I untuk PHM.

\section{Singkatan yang digunakan dalam Pedoman:}

K\&l: Kriteria dan Indikator (Criteria and Indicator) biasa juga digunakan sebagai singkatan untuk menunjukkan keseluruhan hirarki yang saling berhubungan, contohnya, tidak hanya menyangkut Kriteria dan Indikator, tetapi juga Prinsip, Kriteria, Indikator dan Penguji

LSM: Lembaga Swadaya Masyarakat (Non Governmental Organization)

PDK: Petugas Dinas Kehutanan

PHM: Pengelolaan Hutan oleh Masyarakat

PHML: Pengelolaan Hutan oleh Masyarakat secara Lestari

PRA: Participatory Rural Appraisal

UPH: Unit Pengelolaan Hutan (Forest Management Unit) 


\section{Pengelolaan Hutan oleh Masyarakat (PHM)}

\subsection{Mengapa pengelolaan hutan oleh masyarakat penting}

Kebanyakan masyarakat pedesaan, dan khususnya masyarakat asli mempunyai tradisi turun menurun dalam mengelola hutannya, seperti contohnya, pengelolaan sumberdaya hutan menjadi tanggung jawab masyarakat setempat dan praktek pengelolaannya dilakukan melalui upaya kerjasama atau bersama-sama dengan anggota masyarakat. Mereka berhasil membangun sejumlah kebijakan, ilmu pengetahuan dan keterampilan praktis yang dapat dituangkan ke dalam satu tulisan untuk menjamin kelangsungan pengelolaan hutan secara lestari di dunia.

PHM sampai saat ini, di banyak tempat, masih secara aktif dipraktekkan di seluruh dunia, setiap benua dan berbagai tipe hutan mulai dari tropis sampai tundra. Tujuan dan sistem pengelolaannya sangat beragam, mulai 'reindeer herding' di ujung utara melalui sistem agroforestry menetap, sampai perladangan berpindah di hutan tropis. Sistem pengelolaan hutan tersebut biasanya berdasarkan "tata cara/gaya hidup tradisional, dilakukan sepanjang tahun, atas dasar kebersamaan dan mempunyai sangsi keagamaan/ritual". ${ }^{3}$

Dalam cakupan visinya, PHM berbeda nyata dari sudut pandang industri atau ekonomi konvensional pengelolaan hutan. Masyarakat yang hidupnya bergantung pada hutan umumnya memandang hutan dari berbagai perspektif yang berbeda. Mereka menganggap hutan sebagai sebuah ruang yang pernah dihuni oleh pendahulu/nenek moyang mereka, yang pengaruhnya terhadap hutan tersebut dapat dilacak kembali. Lanskap

\footnotetext{
${ }^{3}$ Dari Conklin, H.C. 1957. Hanonoo Agriculture: a report on an integral system of shifting agriculture in the Philippines. Rome: FAO (Forestry Development Paper no.12).
} 
tersebut juga ada dalam ingatan mereka yang dihubungkan dengan nama tempat, mitos dan cerita rakyat.

Bentang alam hutan yang dikelola oleh masyarakat merupakan 'ruang budaya'. Hutan adalah tempat dimana mayarakat memenuhi:

- kebutuhan fisiknya - makanan, bahan bakar, tempat berteduh,obatobatan dan alat;

- kebutuhan sosialnya - ruang individu, keluarga dan masyarakat;

- kebutuhan spiritualnya - contohnya, tempat keramat, tempat pemakaman dan rumah ibadah; dan

- kebutuhan ekonominya - hasil hutan, bahan baku dan kesempatan kerja.

Sampai saat ini, sistem pengelolaan oleh masyarakat biasa dianggap sebagai sebuah anakronisme di era modern, merusak hutan, tidak efisien dan tidak produktif. Pandangan ini umumnya menyebabkan terhambatnya sistem pengelolaan oleh masyarakat (dan tentunya seringkali terhadap masyarakatnya sendiri), selanjutnya mengakibatkan sistem ini berangsurangsur menghilang di beberapa bagian dunia. Penelitian yang dilakukan akhir-akhir ini dan semakin besarnya pemahaman tentang 'bagaimana dan kenapa' sistem PHM ini beroperasi membuat semakin dikenalnya kenyataan bahwa sistem ini dapat bertahan dan bernilai, dan tetap penting di dalam fungsi sosial pedesaan dan sistem ekonomi. Berjutajuta manusia di seluruh dunia masih tergantung kepada sumberdaya hutan untuk kelangsungan hidup mereka, dan akan terus berlanjut sampai kapanpun. Seperti halnya, dengan semakin meningkatnya kebutuhan regional, nasional dan internasional untuk melindungi sumber air dan keanekaragaman hayati, dan untuk membatasi tingkat karbon di atmosfir, masyarakat semakin dikenal sebagai mitra dan pengelola sumberdaya yang penting. 
Tampak pula semakin banyak jumlah masyarakat yang tinggal di sekitar hutan yang tidak mempunyai sejarah tradisi pengelolaan hutan seperti yang digambarkan di atas. Sementara kelompok masyarakat ini misalnya transmigran atau penduduk yang dipindahkan, tidak mempunyai ilmu pengetahuan lokal secara khusus atau berhubungan secara spiritual dengan daerah tertentu, kenyataannya, manusia yang tinggal dekat dengan hutan tetap akan bertindak sebagai aktor utama yang mungkin akan memberikan dampak yang negatif maupun positif terhadap hutan. Kenyataan ini, dikombinasikan dengan berbagai pelajaran konkrit yang diperoleh oleh banyak pemerintah di seluruh dunia bahwa penduduk lokal tidak dapat secara paksa dijauhkan dari hutan, memberikan indikasi kuat perlunya mempertimbangkan masyarakat setempat, dalam hal ini sebagai pengelola lokal, agar didukung dan dilibatkan dalam upaya pelestarian.

Alasan praktis lainnya adalah PHM semakin dikenal dan menjadi pusat perhatian, tanpa memandang komposisi atau susunan masyarakatnya. Hal ini berkaitan dengan kecenderungan banyaknya pemerintah yang akhir-akhir ini mengupayakan desentraliasi dan/atau mengalihkan tanggung jawab dan pengelolaan hutan dan sumberdaya alam lainnya ke tingkat lokal, termasuk kepada masyarakat. Hal ini berakibat meningkatnya kepentingan diantara pemerintah, lembaga donor, LSM dan pada akhirnya masyarakat hutan sendiri untuk memperkokoh dan memperkuat PHM. ${ }^{4}$

\subsection{Apa yang dapat membantu agar PHM berjalan baik?}

Dari analisa yang diperoleh berdasarkan pengalaman di seluruh dunia maka dapat dikenali sejumlah faktor yang berkaitan dengan keberhasilan

\footnotetext{
${ }^{4}$ Contoh, lihat Poffenberger (1998 dan seterusnya)
} 
pengelolaan produk dan sumberdaya hutan yang dikelola oleh masyarakat. $^{5}$ Faktor-faktor tersebut meliputi:

- keanggotaan masyarakat yang jelas;

- batas sumberdaya hutan yang jelas;

- kewenangan pengelolaan (kemantapan status kepemilikan, de facto atau de jure);

- saling berbagi ilmu pengetahuan tentang nilai sumberdaya hutan;

- saling berbagi ilmu pengetahuan tentang fungsi hutan;

- ketergantungan yang lebih tinggi terhadap lembaga internal dibandingkan terhadap lembaga eksternal;

- peraturan yang disusun secara realistis;

- kemampuan untuk memantau dan menegakkan peraturan';

- mekanisme penyelesaian konflik dengan biaya rendah;

- kemampuan untuk memantau kondisi sumberdaya hutan; dan

- teknologi tepat guna untuk kelayakan/peruntukan hasil hutan.

\subsection{Apakah tantangan yang dihadapi PHM saat ini?}

Sumberdaya hutan, masyarakat hutan dan sistem PHM di banyak bagian dunia terus menerus mengalami tekanan dari:

- perubahan situasi politik dan ekonomi di tempat mereka beroperasi;

- meningkatnya permintaan sumberdaya hutan dari pelaku di luar masyarakat;

- menyebarnya pendidikan dan informasi global, termasuk melalui media populer; dan

- bertambahnya populasi di dalam masyarakat.

Hal ini dapat menyebabkan:

- terciptanya permintaan/kesempatan pasar yang baru;

- terciptanya kompetisi sumberdaya hutan tempat masyarakat bergantung;

\footnotetext{
${ }^{5}$ Contoh, lihat Ostrom (1999).

6 Di dalam seluruh teks, kecuali disebutkan secara spesifik, bila kami menyebutkan "aturan", artinya kami melibatkan kedua peraturan dan aturan baik formal dan informal (contoh: norma, tabu, praktek tradisional yang disepakati, dan lain-lain).
} 
- diabaikannya sistem kepercayaan tradisional yang mendukung sistem nilai dan membimbing sistem pengelolaan mereka; dan

- meningkatnya harapan dan aspirasi.

Jika suatu saat sistem PHM terancam atau tidak diindahkan, maka dapat berakibat kepada penggunaan hutan yang tidak lestari, yang menyebabkan timbulnya degradasi hutan atau deforestasi. ${ }^{7}$

\subsection{Penyesuaian terhadap perubahan}

Semua sistem PHM mengalami perubahan sepanjang waktu dan masyarakat belajar untuk menyesuaikan terhadap perubahan yang terjadi di lingkungan politik, budaya dan ekonomi, dan tentunya terhadap perubahan dalam lingkungan fisik yang ditimbulkan oleh intervensi mereka sendiri. Hal ini digambarkan secara baik, misalnya oleh banyak masyarakat hutan yang berpindah yang mengembangkan sebuah sistem penanaman intensif jenis tanaman bernilai tinggi di dalam hutan, sejalan dengan menurunnya lahan hutan yang tersedia dan semakin terbukanya peluang pasar. Tetapi ada kekhawatiran bahwa banyak masyarakat yang mempraktekkan PHM mungkin tidak mampu untuk beradaptasi secara positif dan cepat terhadap banyaknya dan cepatnya perubahan yang mereka hadapi.

Perubahan secara cepat kebanyakan terjadi pada masyarakat ini. Banyak dari perubahan tersebut disebabkan oleh faktor eksternal seperti pembangunan jalan, pendidikan universal, informasi eksternal dan komunikasi yang diperkenalkan ke desa dan kampung halaman mereka. Meskipun sebagian besar perubahan tersebut dapat diterima dengan baik, namun seringkali terbukti merusak sistem pengelolaan tradisional.

\footnotetext{
${ }^{7}$ Contoh, lihat Verolme, H.J.H. dan Moussa, J. (eds.)(1999).
} 
Penyesuaian terhadap perubahan tersebut akan menjadi suatu tantangan yang berat. Ini dapat menjadi sangat merusak jika kecepatan perubahan yang terjadi melebihi kecepatan untuk mempelajari dampaknya terhadap masyarakat dan sumberdaya hutan.

\subsection{Penyesuaian terhadap berubahnya kemitraan}

Salah satu respon dalam menghadapi cepatnya perubahan dan perlunya untuk beradaptasi adalah adanya harapan agar masyarakat dapat bekerja sama dengan pihak stakeholder, termasuk LSM dan departemen pemerintah, di dalam pengelolaan hutan bersama secara kemitraan.

Diantara kesulitan yang dihadapi dalam pengelolaan bersama secara kemitraan adalah komunikasi yang efektif antara mitra non-masyarakat dan masyarakat. Dengan semakin meningkatnya pengakuan akan pentingnya PHM oleh pemerintah, organisasi pengembangan desa dan pihak lainnya, serta keinginan politik untuk mengembalikan pengelolaan kepada masyarakat, maka diharapkan bahwa PHM dapat diarahkan untuk membantu dan membimbing masyarakat dengan baik dalam rangka memenuhi kebutuhannya. Bimbingan terhadap mitra non-masyarakat seringkali diberikan berdasarkan pertimbangan ilmiah dan bersifat global yang mungkin tidak secara cepat dapat diterima atau dimengerti oleh masyarakat, dan sebaliknya tidak secara tepat memahami atau mencerminkan kepentingan masyarakat. Lebih jauh lagi adalah munculnya banyak hambatan dalam masyarakat untuk secara efektif mengekspresikan harapan, kebutuhan, pengetahuan dan keinginan yang ingin mereka capai dari mitranya.

Gagalnya komunikasi secara efektif seringkali menghasilkan situasi yang tegang di dalam pengelolaan bersama, yang akhirnya dapat menjadikan mereka frustasi, dan yang lebih buruk dapat mengakibatkan kehancuran baik secara sosial dan lingkungan serta menghambat kemajuan menuju PHM yang lestari. 


\subsection{Bagaimana K\&l dapat membantu}

Kriteria dan Indikator (K\&l) pengelolaan hutan lestari dapat dijadikan alat komunikasi dan proses belajar yang sangat bermanfaat. K\&l yang mudah diterapkan secara umum atau luas yang dikembangkan di dalam kemitraan sebenarnya berpotensi untuk menjembatani masyarakat dengan dunia luar, dengan jalan membawa informasi ilmu pengetahuan dan pandangan dari luar serta menyebarkan informasi mengenai pandangan, kebutuhan dan keinginan yang ingin dicapai oleh masyarakat.

Di tingkat lokal, pengalaman kami sampai saat ini secara tegas menyarankan bahwa K\&l yang dikembangkan secara lokal oleh stakeholder utama dengan cara kerjasama partisipatif dapat dijadikan alat yang berharga untuk mengambil pelajaran saling menguntungkan antara masyarakat dan mitranya, saling bertukar pengetahuan lokal, ilmiah dan pengetahuan dari luar dan mengarahkan semua langkah menuju pengelolaan hutan yang lestari. Semuanya ini akan menghasilkan suatu struktur organisasi yang melibatkan pertukaran informasi dan ilmu pengetahuan tentang pengelolaan hutan lestari.

Mengembangkan $\mathrm{K} \& \mathrm{I}$ dengan cara partisipatif dapat:

- Menggali kebijakan, ilmu pengetahuan, observasi dan pemahaman lokal;

- Mengekspresikan ilmu pengetahuan tradisional;

- Menggabungkan ilmu pengetahuan ilmiah dan tradisional;

- Mengidentifikasi kesenjangan atau kesalahpahaman;

- Memperkokoh sistem perencanaan, pemantauan, evaluasi dan pelaporan;

- Meningkatkan rasa memiliki di masyarakat terhadap proses pemantauan; dan

- Memperkuat peran suara masyarakat diantara stakeholder lainnya. 
Hasil K\&l dapat digunakan oleh masyarakat sebagai alat untuk menyusun tujuan bagi pengelolaan hutan lestari, membimbing kegiatan, pemantauan dan penilaian serta proses belajar. Penggunaan K\&l dengan proses iteratif dapat membantu mengadaptasi pengelolaan ke arah kelestarian.

Penerapan K\&l sebagai alat pemantauan dapat:

- Memudahkan masyarakat untuk menyusun tujuan pengelolaan hutan lestari;

- Membantu memahami informasi penting menyangkut dampak pengelolaan;

- Membantu penilaian dan evaluasi kemajuan dalam mencapai tujuan;

- Mendorong masyarakat dan mitranya untuk belajar dari dampak negatif dan positif pengelolaan;

- Mendorong masyarakat untuk menerapkan strategi dan langkah pengelolaan berdasarkan pelajaran yang diperoleh dari proses di atas; dan

- Membimbing masyarakat dalam mengkomunikasikan pengalaman pengelolaan mereka kepada stakeholder lainnya.

Proses pemantauan dan pengembangan $\mathrm{K} \& \mathrm{l}$ dapat berbentuk formal atau informal tergantung konteksnya. Kami yakin alat ini sesuai dan sejalan dengan perkembangan konteks $\mathrm{K} \& \mathrm{l}$ dalam bentuk formal (contohnya, pemerintah mengakui Kehutanan Masyarakat melalui dokumen tertulis rencana pengelolaan tahunan) atau sistem PHM yang sedikit formal/ lebih tradisional (contohnya, pada saat pengelolaan diterapkan sepenuhnya secara lisan, kesepakatan masyarakat internal, dan/atau pada situasi dimana pemerintah belum mengakui). (Pada kasus sebelumnya, K\&l harus dipandang sebagai pelengkap, bukan sebagai pengganti dokumen tertulis rencana pengelolaan). 


\section{Apakah Kriteria dan Indikator (K\&I)?}

Secara tertulis K\&l berarti Kriteria dan Indikator, namun di dalam pedoman ini digunakan secara umum dan praktis sebagai singkatan untuk keseluruhan hirarki Prinsip, Kriteria, Indikator dan Penguji. K\&l menyediakan sarana untuk menghubungkan Kebijakan, IImu pengetahuan, Informasi dan Data pada empat tingkat hirarki ke arah sifat yang lebih komprehensif, menyatu dan konsisten sehingga mampu digunakan dalam proses verifikasi. ${ }^{8}$ Dengan cara menciptakan hubungan yang jelas ini maka $K \& l$ dapat dijadikan alat yang sangat berguna di dalam mencapai keseluruhan tujuan pengelolaan hutan lestari. K\&l dapat membantu dalam mengorganisasikan pengetahuan lokal dan ilmiah sedemikian rupa sehingga dapat digunakan sebagai "health check" atau pengukur kesehatan hutan dan pengelolaan hutan.

K\&l yang tersusun secara baik dapat digunakan untuk:

- Mengekspresikan apa arti pengelolaan hutan lestari bagi masyarakat;

- Menilai kinerja terhadap target yang sudah ditetapkan sebelumnya;

- Memantau dampak intervensi pengelolaan;

- Mencatat perubahan;

- Menyediakan pedoman untuk langkah berikutnya ke arah pengelolaan lestari dengan jalan menentukan praktek yang terbaik; dan

- Mengadaptasi strategi pengelolaan berdasarkan apa yang sudah dipelajari dari proses di atas.

8 Lihat juga acuan generik Kriteria dan Indikator yang disusun oleh CIFOR. Hirarki yang berhubungan dengan Tropenbos (serupa, tetapi ada sedikit perbedaan dalam pendekatannya) digambarkan dengan baik oleh Lammerts van Bueren and Blom (1997). 


\subsection{Menetapkan K\&l}

\section{Prinsip}

Prinsip merupakan sebuah pernyataan tingkat pertama - "kebenaran yang hakiki/fundamental' atau "hukum" - yang mendasari kebijakan manusia tentang pengelolaan

Prinsip biasanya dinyatakan sebagai pernyataan yang ideal.

Contoh:

'Terpeliharanya integritas ekosistem' 'Terjaminnya kesejahteraan manusia'

hutan oleh masyarakat secara lestari (PHML). Prinsip ini mengacu kepada fungsi hutan atau aspek relevan dari sistem sosial yang berinteraksi, dan membentuk suatu payung bagi semua Kriteria, Indikator dan Penguji.

\section{Kriteria}

Kriteria merupakan standar untuk mengetahui/menilai apakah kemajuan yang dicapai dapat memenuhi Prinsip. Kriteria merupakan refleksi ilmu pengetahuan yang menambah arti pada Prinsip dan membuatnya Kriteria biasanya dinyatakan sebagai kondisi atau situasi aspek hutan atau negara yang seharusnya, atau proses yang harus dijalankan.

Contoh:

'Perlindungan terhadap sumber air' 'Hasil hutan memberikan sumbangan bagi kesejahteraan masyarakat' menjadi berfungsi dengan cara menetapkan hutan/masyarakat pada kondisi atau situasi tertentu sehingga kita berharap dapat melihat apakah Prinsip yang mendukungnya diperhatikan. Kelompok di dalam Kriteria mendukung masing-masing Prinsip.

\section{Indikator}

Indikator merupakan komponen atau variabel hutan atau sistem pengelolaan yang mencerminkan atau "mengindikasikan" situasi atau kondisi yang diperlukan oleh Kriteria. Indikator disajikan sebagai 'informasi' atau, dengan kata lain, secara tunggal, sebuah Indikator biasanya dinyatakan sebagai sesuatu yang khusus yang dapat dinilai dalam hubungannya dengan Kriteria.

Contoh:

'Terpeliharanya vegetasi di sepanjang sempadan sungai'

'Penghasilan rumah tangga diperoleh dari penjualan hasil hutan'

pesan bermakna tentang komponen atau variabel (terdiri dari satu atau lebih elemen data). (Sementera keberadaanya memberikan kontribusi 
dalam memenuhi Kriteria, indikator tidak boleh diartikan sebagai serangkaian aturan keharusan/mandatorial atau persyaratan).

\section{Penguji}

Penguji merupakan data atau informasi yang diperlukan untuk menilai indikator. Data menentukan detil khusus yang akan menunjukkan apakah indikator terpenuhi. ${ }^{9}$

\subsection{Contoh K\&l}

Penguji biasanya dinyatakan sebagai jenis-jenis informasi yang perlu untuk dikumpulkan.

Contoh:

'Keberadaan vegetasi secara kontinyu di sepanjang sempadan sungai' 'Proporsi penghasilan rumah tangga yang berasal dari penjualan hasil hutan'

Kotak 1 memuat contoh yang diangkat dari perangkat K\&I PHM yang dikembangkan pada lokasi uji CIFOR di Indonesia. Struktur hirarkinya digambarkan pada Gambar 1. Prinsip menyatakan pemahaman yang bijaksana tentang pentingnya peran lembaga masyarakat (badan pengambil keputusan) dan institusi (peraturan, norma, hukum, dll) dalam menjamin kelestarian. Merupakan gambaran aturan yang fundamental atau ideal untuk menjamin tercapainya tujuan PHML.

Selanjutnya ada tiga kriteria yang diusulkan untuk mendukung Prinsip. Ketiganya menentukan elemen dalam mendukung prinsip yang menetapkan standar yang dapat diukur atau dinilai oleh indikator pendukung.

Untuk setiap kriteria, maka diberikan beberapa indikator. Masing-masing menjelaskan jenis informasi yang diperlukan untuk dapat menilai apakah kriteria dapat dipenuhi.

Untuk setiap indikator, satu atau lebih penguji menjelaskan jenis data atau informasi yang perlu diperiksa untuk menguji indikator tersebut.

\footnotetext{
9 Pada beberapa pendekatan K\&l, "penguji" juga didefinisikan sebagai prosedur untuk mengumpulkan informasi atau data (contoh: cara-cara pengujian). Secara sederhana, pemguji diartikan sebagai informasi atau data yang diperlukan, dan cara pengujian tersebut dianggap sebagai pertanyaan "bagaimana untuk" dalam bagian metode pedoman ini (Bagian 3: Pengembangan dan Penggunaan Perangkat K\&l).
} 
N.B.: Perangkat contoh ini diambil langsung dari perangkat kerja yang dikembangkan oleh masyarakat dan tim lokasi uji Indonesia. Perangkat ini ditujukan sebagai contoh tentang bagaimana suatu perangkat aktual $P, K$, I dan V dapat tersusun dengan baik dalam suatu hirarki, namun tidak ditujukan sebagai perangkat "model" untuk diterapkan oleh kelompok masyarakat lain. Jika suatu perangkat akan digunakan di tempat lain, tidak hanya $P, K, I$ dan $V$ yang harus disesuaikan terhadap kondisi setempat, namun dalam hal ini, pembaca akan mengenali bidang/topik dimana P, K, I dan V dapat diperkuat atau diperjelas untuk meningkatkan fungsinya. Secara umum kami tidak mengubah bahasa yang digunakan dalam perangkat tersebut, untuk mempertahankan keaslian spirit dan tujuannya.

Kotak 1. Contoh Prinsip, dengan Kriteria, Indikator dan Pengujinya yang diambil dari lokasi uji CIFOR PHM di Indonesia

\section{Prinsip}

\section{Lembaga sosial setempat/lokal (harus) mendukung sistem tata guna lahan yang lestari}

\section{Kriteria Satu}

Hukum adat dan peraturan lainnya menjamin sistem tata guna lahan lestari.

\section{Indikator}

Adanya peraturan yang menjamin kelestarian pemanfaatan hutan.

\section{Indikator}

Semua anggota masyarakat menghormati hukum adat dan peraturan lainnya yang berkaitan dengan sistem tata guna hutan lestari.

\section{Penguji}

Anggota masyarakat yang dewasa tahu jelas tentang hukum adat yang berlaku pada sistem tata guna hutan.

Masyarakat setuju bahwa hukum adat masih tetap efektif.

Kasus-kasus yang baru terjadi yang memberikan sangsi terhadap adanya pelanggaran.

\section{Indikator}

Pemberian sangsi bagi mereka yang melakukan pelanggaran terhadap peraturan.

\section{Penguji}

Sangsi khusus dikenakan bagi sistem tata guna lahan yang tersendiri.

\section{Indikator}

Tersedianya mekanisme penyelesaian konflik.

\section{Penguji}

Anggota masyarakat yang dewasa dapat mengatakan bagaimana cara memecahkan konflik tataguna lahan.

Tersedianya konsensus tentang bagaimana konflik tata guna lahan diselesaikan. Kasus-kasus yang baru saja terjadi menyangkut penyelesaian konflik tradisional tentang tata guna lahan. 
Kotak 1. (lanjutan) Contoh Prinsip, dengan Kriteria, Indikator dan Pengujinya yang diambil dari lokasi uji CIFOR PHM di Indonesia

\section{Kriteria Dua}

Hukum adat dan peraturan lainnya menjamin akses yang terbuka terhadap sumber daya alam masyarakat dan distribusi hasil yang adil diantara anggota masyarakat.

\section{Indikator}

Adanya aturan yang menjamin akses yang adil seluruh stakeholder terhadap hutan.

\section{Penguji}

Pengertian yang jelas tentang komposisi stakeholder.

Setiap kategori stakeholder mempunyai akses terhadap hutan sesuai dengan hukum adat dan peraturan lainnya.

Stakeholder menghormati hukum adat dan peraturan menyangkut sumber daya alam.

\section{Kriteria Tiga}

Lembaga sosial setempat/lokal mempunyai kapasitas untuk menegakkan hukum adat dan peraturan lainnya.

\section{Indikator}

Diadakannya pertemuan untuk membahas masalah tata guna lahan dan lingkungan.

\section{Penguji}

Kasus pertemuan masyarakat yang baru dilakukan menyangkut permasalahan lingkungan dan tata guna lahan.

Pihak yang relevan dalam konflik hadir.

Anggota masyarakat lainnya disamping pihak yang berkonflik hadir.

Ada keputusan yang dibuat.

\section{Indikator}

Wanita terwakili secara setara dengan anggota lainnya dalam pertemuan dan pengambilan keputusan.

\section{Penguji}

Wanita hadir pada saat pertemuan.

Wanita terlibat dalam diskusi.

\section{Indikator}

Pengambilan keputusan dilakukan secara partisipatif.

\section{Penguji}

Dalam pertemuan, keputusan dibuat oleh anggota masyarakat yang telah dewasa.

Peserta memahami topik diskusi.

Tidak ada monopoli diskusi oleh pihak yang berkuasa.

\section{Indikator}

Peraturan baru dan sangsi yang berhubungan dengan perkembangan baru menyangkut tata guna lahan dan sumberdaya alam sedang dikembangkan.

\section{Penguji}

Masyarakat dapat membedakan aturan tradisional dan aturan baru yang telah disepakati bersama oleh masyarakat.

Aturan/peraturan baru telah dimulai secara lokal. 
Gambar 1. Struktur Hirarki

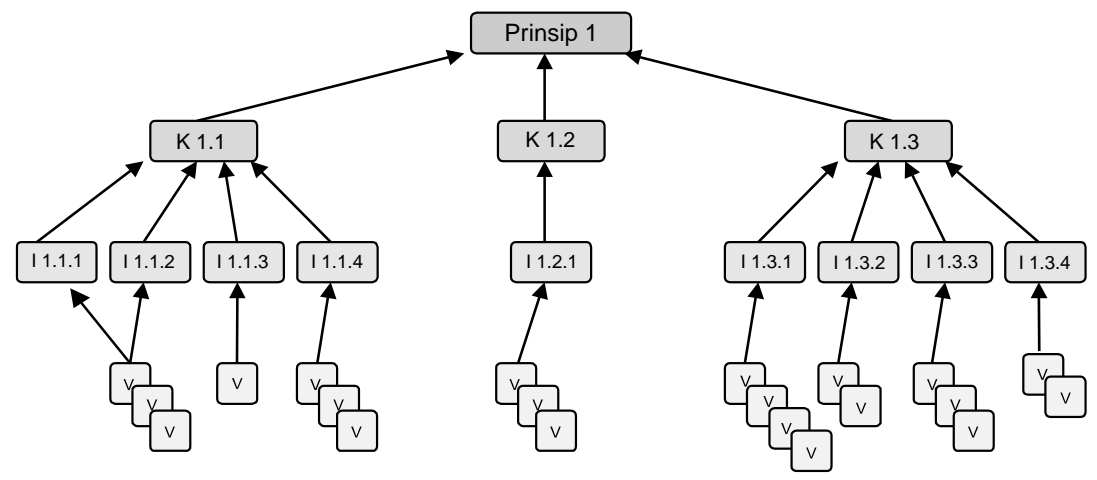

\section{Petunjuk tentang K\&l:}

- Maksud struktur hirarki secara keseluruhan adalah untuk menciptakan hubungan yang kokoh antara tujuan pada tingkat atas (Prinsip) dan 'tanda' (Kriteria dan Indikator), turun hingga ke bagian terkecil dari informasi (Penguji), sehingga gambaran yang diciptakan bermakna dan utuh. Tidak akan terjadi masalah dengan mengadaptasi kerangka kerja ini, atau kerangka kerja K\&l lainnya untuk memenuhi kebutuhan lokal, selama fungsi dan logika dasarnya tetap terjaga utuh.

- Dibuat agar mudah dikerjakan. Hindari keinginan untuk memasukkan semuanya - berusaha untuk memusatkan hanya pada prioritas saja, dan mencari I (Indikator) \& V (Penguji) yang efektif sehingga sesuai dengan praktek pengumpulan informasi yang diadaptasi saat ini, jika mungkin.

- Indikator seringkali tampak sesuai untuk lebih dari satu Kriteria. Daripada dua kali, indikator tersebut dapat diperlakukan sebagai indikator crosscutting yang dapat dipergunakan untuk lebih dari satu keperluan. Hal yang sama berlaku untuk Penguji - untuk menjaga agar jumlah informasi yang perlu dikumpulkan dan dinilai seminimal mungkin, beberapa Penguji dapat dipergunakan untuk dua atau lebih indikator.

- Perbedaan antara Indikator dan Penguji kadang-kadang bisa tidak jelas. Seperti gambar di atas, yang terpenting adalah menjaga hubungan yang kokoh antara $\mathrm{P}$, $\mathrm{K}$, I dan V (Penguji) dan tidak perlu terlalu cemas tentang terminologi struktur hirarkinya.

Petunjuk selebihnya menyangkut topik ini diberikan di Bagian 3.4 


\section{Mengembangkan dan Menggunakan Perangkat K\&l}

Bagian ini mengulas proses pengembangan perangkat $K \& l$ yang sesuai dengan kondisi setempat. Proses ini meliputi ringkasan beberapa pengalaman CIFOR menggunakan K\&I PHM, menelusuri kerjasama dan partisipasi sebagai elemen penting dari penerapan K\&l, kemudian membuat kerangka pendekatan yang mungkin dilakukan untuk menggunakan K\&l berdasarkan pengalaman yang diperoleh CIFOR sampai saat ini.

\subsection{Latar belakang: Ringkasan penelitian K\&I CIFOR}

\section{Mengembangkan dan menguji K\&l untuk pengelolaan hutan lestari (PHL)} dalam unit pengelolaan hutan (UPH) komersial

Penelitian ini dilakukan sehubungan dengan tingginya permintaan K\&l yang konsisten dan hemat biaya untuk menilai pengelolaan kayu terutama untuk keperluan sertifikasi. Kajian dimulai dengan dikembangkannya metode untuk menguji relevansi dan kegunaan beberapa perangkat K\&l yang telah ada dan telah diterapkan secara lebih luas, yang dikembangkan untuk produksi kayu di kawasan hutan alam. Lima pengujian terhadap perangkat K\&l yang telah dikembangkan untuk menilai kelestarian pengelolaan kayu komersial dilaksanakan di unit pengelolaan hutan di Ivory Coast, Brasil, Indonesia, Austria dan Jerman. ${ }^{10}$ Uji ini dilaksanakan oleh tim antar disiplin (interdisciplinary), yang melibatkan Uji lapangan K\&l, dan diselesaikan dalam waktu sekitar satu bulan.

\section{Mengembangkan dan menguji K\&l untuk PHM ${ }^{11}$}

CIFOR melakukan pengujian K\&l yang sesuai untuk PHM di tiga lokasi di Brasil, Kamerun dan Indonesia. ${ }^{12}$ Seperti kegiatan UPH di atas, pengujian ini

\footnotetext{
10 Lihat Prabhu et al. (1996).

${ }^{11}$ Lihat Buford de Oliviera et al. (1999).

12 Kelompok masyarakat yang terlibat adalah: Sao Paulo (Sungai Arapiuns) dan Cachoiera de Maro (Sungai Maro), Para, Brazil; Bedigong dan Darok, Kabupaten Sanggau, Kalimantan Barat, Indonesia; dan desa-desa Eyek II dan Akak/Bitetele, Arrondissement dari Endom, Provinsi Tengah, Kamerun. Beberapa wawasan penelitian K\&I PHM hutan yang dikelola, ada dalam pedoman ini, tidak akan terwujud tanpa usaha dan kontribusi dari masyarakat tersebut.
} 
dilakukan oleh tim antardisiplin, yang terdiri dari ahli ekologi, ahli pengelolaan hutan dan ilmuwan sosial.

Untuk setiap uji, satu atau dua petunjuk perangkat K\&l untuk pengelolaan hutan atau sumber daya alam dipilih sebagai titik awal demikian pun dengan satu atau dua perangkat K\&l Tahap 1 CIFOR. ${ }^{13}$ Perangkat dasar yang digunakan berbeda pada setiap uji. K\&l yang relevan dari perangkat dasar (atau pedoman) yang ada, bersama K\&l tambahan, mengalami proses iteratif pengulangan atau penyempurnaan. Bagian ini terdiri dari empat tinjauan yang disebut sebagai saringan (lihat Kotak 2) dan melibatkan uji lapangan dengan partisipasi masyarakat. Perangkat

Kotak 2. Tinjauan terhadap "proses penyaringan" K\&I PHM tim uji CIFOR

\section{Saringan 1.}

Pada tahap awal ini anggota tim secara individu memilih K\&l yang relevan dari Perangkat Dasar K\&l yang diberikan dan mengusulkan tambahan $K \& l$ yang mereka anggap penting. Proses penyaringan secara individu yang pertama ini menghasilkan tiga sub-perangkat awal K\&l (satu untuk setiap disiplin: Ekologi, Sosial ekonomi dan Pengelolaan Teknis)

\section{Saringan 2.}

Saringan ini merupakan hasil perbaikan $K \& l$ yang diperoleh melalui Saringan 1 oleh tim antar disiplin. Anggota tim menyadari bahwa perangkat yang dihasilkan selama penyaringan ini tidak akan menjawab semua isu yang mempengaruhi kelestarian pada lokasi uji mereka yang telah ditentukan dan/atau isu yang diprioritaskan oleh anggota masyarakat setempat. Oleh karena itu mereka diminta untuk tetap menyimpannya untuk penyaringan berikutnya (yang akan dilakukan di lokasi).

\section{Saringan 3.}

Saringan ke tiga adalah uji lapangan K\&l yang dilaksanakan selama 10 - 14 hari oleh tim penguji secara konsultasi dengan kelompok dalam masyarakat setempat yang tertarik pada masalah hutan. Selama uji lapangan, tim terdorong untuk menuangkan pengalaman profesional mereka dalam Participatory Rural Appraisal (PRA) dan teknik lainnya untuk memudahkan anggota masyarakat untuk memberikan kontribusi secara aktif pada tahap seleksi dan pengembangan $\mathrm{K} \&$.

\section{Saringan 4.}

Saringan terakhir adalah tinjauan $K \& l$ oleh partisipan/peserta di dalam sebuah workshop. Peserta workshop diminta untuk menilai kesesuaian K\&l yang dipilih untuk kondisi lokasi uji, sambil membayangkan karakteristik PHM lainnya yang mereka kenal dengan baik

\footnotetext{
${ }^{13}$ Sangat sulit untuk menentukan "perangkat dasar" asli yang akan dipilih untuk PHM. Oleh karena itu, tim menarik kesimpulan dari bermacam-macam sumber yang berbeda sehubungan dengan lokasi dan tim yang berbeda pula. Sumber "perangkat dasar" terdaftar pada Lampiran 2.
} 
saringan ini memberikan satu kesempatan untuk memperbaiki dan memunculkan pernyataan baru serta meniadakan pengulangan dalam penerapan $\mathrm{K} \& \mathrm{l}$ yang dianggap ambisius dan/atau sulit serta mahal.

Walau tim penguji mendorong masyarakat di lokasi uji untuk berpartisipasi dalam pengembangan dan pemilihan $\mathrm{K} \& \mathrm{l}$, namun keputusan akhir menyangkut komponen $\mathrm{K} \& \mathrm{l}$ yang akan diterima ada di tangan anggota tim ahli.

Contoh pemilihan yang dihasilkan dari uji K\&l ini disajikan pada Bagian 4 dari buku pedoman ini.

\section{Kemajuan kegiatan K\&I CIFOR: Pendekatan partisipatif dan adaptif}

Pengalaman yang diperoleh dari partisipasi masyarakat di tiga lokasi uji meyakinkan CIFOR bahwa masa depan pengembangan K\&l untuk PHML sangat memerlukan proses yang melibatkan partisipasi penuh mereka secara penuh. Masyarakat yang terlibat tidak hanya menunjukkan sejumlah pengetahuan dan kebijakan aktual mereka mengenai hutan, tetapi juga memperlihatkan kesadaran yang mendalam tentang adanya pengaruh dan penyebab kecenderungan serta dampak dari kegiatan yang mereka lakukan terhadap hutan dan masyarakat sendiri. Pengetahuan dan kesadaran ini ada pada masyarakat yang mempraktekkan PHM. Dibangunnya proses saling bertukar ilmu pengetahuan, belajar dan meningkatnya kesadaran, baik antaranggota masyarakat maupun antara masyarakat dengan mitra dari luar masyarakat menyebabkan semakin baiknya pemahaman dan kesepakatan tentang berbagai hal yang diperlukan untuk menjamin kelestarian pengelolaan sumberdaya hutan. Lebih jauh, tujuan pengembangan K\&l adalah penggunaan dan penerapannya dalam proses pengambilan keputusan: jika masyarakat ingin berperan sebagai pemilik K\&l sedemikian rupa sehingga memungkinkan mereka untuk menggunakan dan menerapkannya dalam pengambilan keputusan, mereka harus menjadi pemain kunci dalam keseluruhan proses termasuk memulainya dari perkembangan pada tahap awal. 
Dalam konteks CIFOR, pendekatan yang digunakan dalam K\&l ditempatkan pada sebuah kerangka kerja untuk mencari peningkatan kerjasama dan kesesuaian dalam pengelolaan hutan. ${ }^{14}$ Singkatnya, kerangka kerja ini menekankan kemampuan pada metode seperti $K \& l$ untuk memperlancar arus informasi dan saling belajar diantara para stakeholder hutan, sehingga pengambilan keputusan dapat diperbaiki dan dilakukan secara adil.

Pada beberapa halaman berikutnya kami menyarankan prinsip-prinsip arahan untuk mengelola proses partisipasi yang diambil dari pelajaran dalam uji K\&l PHM CIFOR.

\subsection{Persiapan untuk mengembangkan dan menggunakan K\&l: Pertanyaan yang harus diajukan sebelum Anda memulai}

Sebelum menyusun proses pengembangan perangkat $K \& l$ perlu diajukan beberapa pertanyaan seperti di bawah ini, dan membuat jawaban yang sesuai dengan apa yang Anda rasakan.

\section{Siapa yang akan memulai dan siapa yang akan terlibat dalam proses?}

Mengingat unsur partisipasi adalah ujung tombak dari proses, sangat perlu untuk memperjelas kelompok-kelompok ('kategori') orang yang membentuk masyarakat (misalnya, kelompok etnis, kategori kesejahteraan, perempuan dan laki-laki, dll.) - masalah ini dibahas lebih lanjut pada Bagian 3.3 - dan untuk mengidentifikasi kelompok utama stakeholder dari luar yang perlu dilibatkan.

Sebagai “tim" yang akan memulai dan/atau menjadi fasilitator, masyarakat yang memulai proses K\&l bisa memilih untuk bekerja secara mandiri (misalnya, mempunyai kelompok masyarakat yang mengelola dan memfasilitasi proses), atau mengedarkan informasi dan/atau keahlian yang ada dengan cara mengundang orang lain atau suatu lembaga untuk mendukung mereka. Orang luar mungkin dapat dilibatkan untuk memberikan keahlian

\footnotetext{
${ }^{14} \mathrm{Hal}$ ini ditempatkan dalam program CIFOR tentang "Devolution, Local People, and Adaptive CoManagement". Anda dapat menghubungi CIFOR untuk keterangan lebih lanjut.
} 
(keahlian sebagai fasilitator, keahlian dalam mengidentifikasi stakeholder, atau ilmu pengetahuan ilmiah dan lainnya). ${ }^{15}$

Jika seseorang dari luar atau lembaga yang berinisiatif - mungkin tenaga penyuluh atau Petugas Dinas Kehutanan (PDK) - mereka mungkin dapat bekerja dengan anggota masyarakat untuk mengembangkan dan menggunakan perangkat K\&l PHM, sepanjang masyarakat mendukungnya. Jika masyarakat menemukan adanya jurang/perbedaan ilmu pengetahuan, fasilitator dapat mencari kemungkinan untuk melibatkan ahli yang berpengalaman di bidang pengetahuan tertentu untuk mengisi kesenjangan tersebut.

Skenario alternatif dapat digunakan jika secara pasti, atau secara jelas akan lebih menguntungkan jika bekerjasama dengan pihak ketiga dalam bidang pengelolaan hutan, misalnya pada masyarakat di dalam kawasan yang dilindungi, kawasan taman (nasional, wisata, dan lainnya), dan keterlibatan PDK atau LSM. Pada situasi ini, kelompok yang mengembangkan dan menggunakan $\mathrm{K} \& l$ dapat melibatkan, termasuk masyarakat, pemeran utama dari mitra pengelola lainnya (atau mitra yang mampu) yang dapat memberikan sejumlah keahlian dan ilmu pengetahuan tambahan yang sesuai. Walaupun masih ada kekurangan seperti kesulitan dalam merekonsiliasi berbagai pandangan dari stakeholder yang berbeda, pendekatan ini mempunyai keuntungan dalam meningkatkan kerjasama melalui terbentuknya kerangka K\&l bersama, dan lebih hemat biaya bagi masyarakat.

Petunjuk: Jika mungkin, akan lebih bermanfaat untuk melibatkan anggota masyarakat lain yang pernah terlibat dalam mengembangkan dan menggunakan K\&l PHM - mungkin mereka dapat memberikan sumbangan yang berarti tentang jalannya proses dilihat dari sudut pandang masyarakat.

\footnotetext{
${ }^{15}$ Pendekatan yang digunakan CIFOR dalam pengembangan dan pengujian K\&l dipercayakan pada tim ahli dari disiplin ilmu yang berbeda-beda -yaitu ahli kehutanan, ilmuwan sosial atau antropolog, dan ekolog. Para ahli ini memprakarsai pemilihan K\&l, kemudian bekerja dengan masyarakat. Ini bisa terjadi karena sebelumnya CIFOR telah mulai membahas "prakarsa penelitian" dengan para ahli tersebut. Pendekatan ini pada beberapa masyarakat mungkin sulit pada awalnya, terlalu mahal dan mungkin tidak penting, atau bahkan diperlukan sekali karena hal tersebut benar-benar bukan untuk menggerakan masyarakat.
} 


\section{Dimana proses akan dilaksanakan?}

Jika Anda bukan anggota masyarakat yang berencana menggunakan $\mathrm{K} \& \mathrm{l}$ di daerah Anda, tetapi tertarik untuk mendukung dan mengembangkannya di suatu tempat (misalnya, petugas kehutanan atau LSM), maka yang menjadi isu adalah pemilihan lokasi untuk menerapkan $\mathrm{K} \& \mathrm{l}$ sebagai alat bantu pengelolaannya, terutama jika proses ini baru pertama kali dicoba. Pertimbangan yang sangat penting adalah bekerja di lokasi yang kemungkinan besar akan memberikan kesuksesan. Apakah masyarakat tampak antusias? Apakah ada kegiatan yang akan dibangun? Apakah sumberdaya hutan masih utuh? Apakah ada insentif untuk keterlibatan masyarakat?

\section{Bagaimanakah kondisi setempat?}

Apakah bahasa lokal yang digunakan oleh masyarakat dan apakah semua tim fasilitator/inisiator K\&I menguasai bahasa tersebut? Jika tidak, bagaimana mengatasi masalah interpretasi? Bagaimana tingkat kemampuan membaca masyarakat dan apakah metode partisipatif yang sesuai untuk tingkat tersebut sudah ditentukan? Apakah ada keterbatasan musim menyangkut waktu pelaksanaan proses (waktu sibuk tahunan masyarakat, kondisi saat dimana akses menjadi sulit, dII)?

\section{Apakah kelompok inisiator mempunyai "perilaku baik"?}

Yang paling utama adalah bahwa kelompok inisiator atau yang mempunyai inisiatif (baik yang semuanya terdiri dari masyarakat, atau dari stakeholder luar, atau gabungan keduanya) dapat menerima bahwa ini adalah sebuah latihan berbagi ilmu pengetahuan. Biasanya orang yang 'berpendidikan tinggi' dan/atau terlatih secara ilmiah cenderung mendominasi diskusi kelompok dan menggunakan ungkapan dan konsep ilmiah yang tidak mudah untuk dipahami oleh anggota masyarakat. Karena itu, kelompok inisiator perlu mengingat dan menekankan bahwa yang diharapkan adalah tingginya partisipasi masyarakat dan bahwa semua partisipan perlu sepenuhnya mengerti, mendukung dan menerapkan $\mathrm{K} \& \mathrm{l}$. K\&l harus dibangun berdasarkan 
keahlian/kemampuan, pemahaman dan ilmu pengetahuan setempat. Apakah semua anggota dalam proses pengembangan $\mathrm{K} \& \mathrm{I}$ mempunyai kemauan untuk berbagi atau saling bertukar ilmu pengetahuan? Apakah mereka dapat menerima ide baru? Apakah orang dari luar menghormati masyarakat dan tertarik untuk belajar dari mereka? Apakah ada ketidakseimbangan kekuatan di dalam kelompok? ${ }^{16}$ Apakah setiap orang sudah siap menyediakan waktunya untuk melaksanakan proses tersebut?

\section{Apakah Anda mengenali dan memahami metode partisipatif?}

Karena kami merekomendasikan pendekatan partisipatif sepenuhnya, maka sangat bermanfaat untuk melibatkan seseorang yang ahli dalam menggunakan metode partisipatif (misalnya, dalam hal memfasilitasi). Atau jika Anda melakukannya sendiri dan masih baru dalam hal partisipasi, maka sebaiknya manfaatkan waktu sejenak untuk mengenali dan mempelajari sejumlah metode dan alat untuk melakukan pendekatan partisipatif yang digunakan selama proses. Jika ini merupakan hal baru bagi Anda, merupakan ide yang bagus untuk mencobanya di lingkungan yang telah Anda kenal dengan baik, dengan rekan yang mendukung, untuk membangun kemampuan memfasilitasi dan membangun rasa percaya diri dalam mempraktekkan pengelolaan partisipatif. ${ }^{17}$

\section{Apakah tujuan dari proses K\&I telah dibicarakan bersama dan dipahami dengan jelas?}

Tujuan mengembangkan perangkat K\&l PHM merupakan hal yang sangat penting untuk diperjelas mulai dari awal. Tujuan ini, setidaknya yang utama, harus dibicarakan bersama (di dalam masyarakat dan dengan stakeholder lainnya jika terlibat). Berdasarkan hal ini, anggota

\footnotetext{
${ }^{16}$ Lihat Edmunds dan Wollenberg (yang akan datang) untuk penjelasan yang teoritis namun bermanfaat mengenai resiko masyarakat yang bernegosiasi dengan multi-stakeholder, khususnya penggunaan pendekatan untuk "menetralisir" atau menekankan kembali perbedaan kekuatan yang nyata diantara mereka selama proses negosiasi berlangsung (tetapi tidak untuk jangka panjang). Pertimbangan dan resiko ini tentunya diterapkan dalam proses $K \& l$.

${ }^{17}$ Terdapat banyak sumber metode dan alat partisipatif yang baik. Lihat bagian bahan acuan. Di sebagaian besar daerah, pelatihan dalam penggunaan alat dan metode partisipatif dapat dilakukan. Lihat daftar dalam bagian bahan acuan.
} 
masyarakat harus memahami manfaat dan akibatnya bagi mereka, dan berkeinginan untuk terlibat dalam proses. Tanpa adanya pengertian yang jelas mengenai keseluruhan tujuan mungkin tanpa pertimbangan matang mereka tidak berkeinginan untuk berpartisipasi atau bingung, dan akhirnya menimbulkan kekecewaan. Pertanyaan yang harus dipertimbangkan antara lain: Siapa yang membuat keputusan untuk mengembangkan perangkat K\&l? Apakah ada hak kepemilikan masyarakat terhadap keputusan yang fundamental tersebut? Apakah ada konsensus bahwa ini merupakan ide yang baik dan komitmen yang luas bagi proses?

Masyarakat (dan mitra lain jika perlu) sejak awal perlu memutuskan untuk siapa K\&l ini nantinya. Pertanyaan yang harus dipikirkan antara lain: Apakah akan dihasilkan dan digunakan oleh (hanya) masyarakat sendiri? Ataukah akan dihasilkan dan digunakan oleh masyarakat bekerjasama dengan mitra lain (misalnya, dalam hubungan "co-management"/pengelolaan bersama)? Pada masing-masing kasus apakah bantuan luar diperlukan (misalnya, fasilitator, nara sumber)? Siapa yang bertanggung jawab terhadap bagian per bagian dari proses? Siapa yang akan melakukan pemantauan? Siapa yang dapat menggunakan informasi dan bagaimana?

\section{Apakah setiap orang mengerti apa yang akan terjadi selanjutnya?}

Sebelum memulai mengembangkan $\mathrm{K} \& \mathrm{l}$ semua pelaku harus sepakat tentang bagaimana proses akan diatur, berapa lama, seberapa banyak tenaga yang dilibatkan, dan apa saja peran yang akan mereka jalankan dalam proses. Untuk membantu memastikan proses dapat berjalan dengan baik, sebaiknya dibicarakan rencana yang diusulkan beserta kemungkinan perubahannya agar sesuai dengan pilihan dan keterbatasan yang ada pada kelompok masyarakat yang lebih luas dan mitra lain. 


\subsection{Penentuan stakeholder: Siapa yang perlu untuk dilibatkan?}

Sebelum Anda mulai mengembangkan C\&l maka perlu disusun beberapa pengertian yang sama dan mulai berbagi ilmu pengetahuan dan mendengarkan seluruh anggota masyarakat. Hal ini merupakan kesempatan yang paling baik jika Anda benar-benar akan memulainya - dengan partisipasi aktif dan penuh.

\section{Siapa stakeholder di dalam masyarakat dan di luar masyarakat?}

Penting sekali untuk menentukan siapa saja dalam masyarakat yang berkepentingan terhadap hutan, termasuk perempuan, kelompok minoritas, kaum tua dan muda. ${ }^{18}$ Seringkali ada stakeholder lain yang sebenarnya bukan anggota masyarakat; setidaknya mereka harus diidentifikasi dan dilibatkan pada beberapa tahapan (termasuk yang baru saja diinformasikan), meskipun bagaimana dan kapan dilakukan akan bervariasi. Perlu dicapai kesepakatan oleh mereka yang terlibat dan akan terlibat dalam menentukan stakeholder dan bagaimana mereka akan dilibatkan. Siapa, misalnya, yang akan dilibatkan dalam mengembangkan K\&l? Siapa yang akan bertanggung jawab dalam penerapannya? Siapa yang akan melakukan pemantauan?

\section{Bagaimana struktur kekuatan setempat?}

Pengelolaan melibatkan penggunaan kekuatan untuk menegakkan keputusan. Sangat penting untuk membangun tempat dimana kekuatan berpusat di dalam masyarakat. Apakah mereka berkeinginan melakukan proses K\&l? Apakah Anda mampu meyakinkan bahwa kekuatan yang lebih kecil (misalnya, perempuan, kelompok minoritas, kaum dewasa) mempunyai suara yang kuat dan jelas dalam proses pembangunan K\&l? Apakah ada pusat kekuatan di luar masyarakat yang perlu untuk

\footnotetext{
${ }^{18}$ Adanya metode yang telah dikembangkan untuk mengidentifikasi para stakeholder, termasuk garis besar dalam "THE BAG yang dikeluarkan CIFOR (CIFOR Methods Testing Team 1999), Petunjuk "Who Counts?" yang dikeluarkan oleh CIFOR (Colfer et al. 1999) dan FAO's Tree and Land Tenure Rapid Appraisal Tools (Freudenberger 1994). Lihat bahan acuan untuk lebih jelasnya.
} 
dipertimbangkan? Beberapa alat bantu yang bermanfaat dan tersedia luas juga tersedia untuk membantu dalam hal ini. ${ }^{19}$

\section{Siapa melakukan apa, kapan dan dimana?}

Pada permulaan proses perlu ditetapkan batasan sebuah lanskap hutan dan sampai seberapa jauh pengaruh masyarakat (dalam banyak kasus hal ini tidak ditentukan dengan jelas atau disepakati bersama). Juga sangat penting untuk menyusun apa saja kegiatan yang utama di dalam kawasan dan siapa yang akan melaksanakan.

Ada banyak teknik yang sudah dipraktekkan dengan baik dalam menetapkan dan memetakan batas sumberdaya hutan dan mengenali siapa saja yang menggunakan sumberdayanya, untuk apa, kenapa dan kapan. ${ }^{20}$ Latihan pemetaan partisipatif dan pembuatan kalendar kegiatan akan menyenangkan, dapat melibatkan banyak orang dalam prosesnya, dan dapat menjadi cara yang paling baik dalam membangun pemahaman bersama tentang situasi yang sedang terjadi.

\subsection{Titik awal K\&l: Perangkat dasar, standar atau visi?}

Pada saat semua orang sudah mempunyai ide yang baik tentang siapa melakukan apa, dimana dan bagaimana masyarakat secara bersamasama beroperasi dan siapa saja stakeholder yang terlibat, maka bagaimana Anda akan memulai untuk membangun perangkat $K \& l ?$ Tidak ada satu jawaban yang benar-benar tepat bagi pertanyaan tersebut dan semuanya sangat tergantung pada tujuan Anda. Dalam hal ini diperlukan kepekaan Anda terhadap pandangan masyarakat dan mitra

\footnotetext{
${ }^{19}$ Lihat Tree and Land Teure Rapid Appraisal Tools yang dikeluarkan oleh FAO (Freudenberger, 1994), khususnya pemetaan sosial menggunakan Diagram Venn, untuk pendekatan partisipasi dalam rangka mengidentifikasi kekuatan struktur. Lihat bahan acuan untuk lebih jelasnya.

${ }^{20}$ Lihat contoh, "Community Toolbox" yang dikeluarkan oleh FAO, Tool 14 (Kasus 1990) dan "Tree and Land Tenure Rapid Appraisal Tools" yang dikeluarkan oleh FAO (Freudenberger, 1994), khususnya peta, transek dan kalender. Lihat bagian bahan acuan untuk lebih jelasnya.
} 
lainnya. Disini kami menyarankan tiga pilihan yang akan menunjukkan kepada beberapa kemungkinan titik awal (point of entry) ke dalam proses pengembangan $\mathrm{K} \&$.

\section{Mulai dengan perangkat $K \& I$ yang dibangun oleh orang lain}

Mungkin tampaknya seperti "menyontek" tetapi pada kenyataannya merupakan titik awal yang mudah dikenali, direkomendasikan oleh CIFOR dalam Pedoman untuk mengembangkan, menguji dan memilih K\&l. ${ }^{21}$ Kebanyakan dari pekerjaan yang ada dalam mengembangkan K\&l berisi perubahan dan modifikasi perangkat konsep K\&l sehingga menjadi semakin sesuai dan relevan bagi situasi setempat. Membangun berdasarkan hasil kerja orang lain yang sudah memulai proses terlebih dahulu dapat menghemat waktu, dan dapat berperan sebagai alat bantu memori yang baik dan menjadi sumber ide. Akan membantu sekali jika kita bisa memperoleh contoh yang baik tentang jenis perangkat $\mathrm{K} \&$ yang tampaknya dapat membantu setiap orang untuk menjadi terbiasa dan mengenali konsep tersebut. Acuan generik K\& CIFOR ${ }^{22}$ atau contoh studi kasus K\&I PHM (lihat Bab 4) dapat menjadi titik awal yang berguna.

Bagaimanapun juga, ada kerugian dengan memulai dari perangkat K\&l tersebut yang dibangun oleh orang lain. Pertama, perangkat K\&l tersebut sangat membutuhkan perubahan karena pasti memuat banyak ide dan kalimat yang khusus disesuaikan pada lokasi tempat dikembangkannya perangkat tersebut, dan tidak relevan bagi tempat dimana Anda akan bekerja (atau dalam hal acuan generik CIFOR - perangkat ini bersifat umum, sehingga memerlukan penyesuaian yang lebih spesifik). Perangkat seperti ini dibangun berdasarkan asumsi atau perangkat dasar

\footnotetext{
${ }^{21}$ Lihat Prabhu et al. (1998).

22 Perlu dicatat bahwa perangkat ini ditujukan untuk Unit Pengelolaan Hutan yang bersifat komersial, dan oleh karenanya pendekatan kelestarian diambil dari berbagai pandangan yang agak berbeda. Lihat Toolbox C\&l yang dikeluarkan oleh CIFOR, Tool 2 (Tim C\&I CIFOR, 1999).
} 
yang bias yang dibuat oleh banyak orang, dan akan makan banyak waktu untuk mengubah atau menggantinya. Dan juga, kebanyakan perangkat $K \& l$ yang tersedia secara luas dikembangkan oleh "tenaga teknis atau ilmiah", dan terutama ditujukan bagi pengelolaan hutan secara komersial, sehingga tidak seluruhnya relevan.

\section{Memulai dengan standar}

Beberapa negara mengembangkan standar nasional sendiri untuk mengelola hutannya secara lestari, dan ini mungkin merupakan tempat yang berguna untuk memulai proses. Isi standar nasional ini tampaknya secara umum relevan dengan lokasinya, dan jika sesuai, dapat mudah dimengerti pada tingkat Prinsip dan Kriteria. Meskipun demikian (terutama jika sudah dirancang untuk mengatur industri logging atau pengelolaan hutan tanaman industri), standar seperti ini mungkin tidak berorientasi secara baik pada pengelolaan hutan oleh masyarakat, dan mungkin tidak akan terstruktur dengan baik sebagai suatu hirarki.

Penetapan standar juga dapat diperoleh dari suatu badan atau organisasi seperti Forest Stewardship Council, ${ }^{23}$ yang mengeluarkan sertifikasi hasil hutan. Masyarakat dapat menggunakan organisasi tersebut jika ingin melaksanakan proses sertifikasi. Perusahaan atau organisasi-organisasi lain yang menawarkan jasa sertifikasi dan menilai praktek pengelolaan hutan, dapat menyediakan contoh standar yang mereka gunakan yang telah dimodifikasi dengan memperhatikan kondisi setempat yang mirip dengan kondisi yang ada dalam masyarakat yang bersangkutan.

\section{Bermula dari visi masyarakat mengenai pengelolaan hutan lestari}

Pendekatan ketiga dimulai dengan mengisi selembar kertas dan membuat rancangan perangkat $\mathrm{K} \& \mathrm{l}$ yang disusun dari gambaran kasar yang ada di masyarakat. $K \& l$ tersebut disusun dengan cara membangun visi masyarakat lokal menyangkut kelestarian pengelolaan hutan berdasarkan wawasan dan pengetahuan setempat. Jika mitra yang

\footnotetext{
${ }^{23}$ Lihat bagian bahan acuan.
} 
diikutsertakan lebih banyak, maka mereka juga dapat membangun visi yang dapat saling dibandingkan dan kemudian digabungkan hingga tercapai kesesuaian.

Pengalaman yang diperoleh CIFOR di tiga negara yang uji menggambarkan dengan jelas bahwa pengetahuan lokal sangat luas dan dapat dipercaya. Hubungan jangka panjang dan keterkaitan antara masyarakat setempat dengan hutan serta ketergantungannya terhadap hutan membuat mereka menjadi peka terhadap perubahan-perubahan dan memungkinkan mereka untuk mengenali hubungan sebab-akibat yang berbeda-beda. Pada umumnya mereka juga menyadari akibat campur tangan mereka sendiri atau pihak ketiga.

Dengan memulai dari pandangan masyarakat mengenai pengelolaan hutan lestari, maka keuntungannya adalah memastikan bahwa $\mathrm{K} \& \mathrm{I}$ sepenuhnya menjadi milik masyarakat dan merupakan produk yang yang secara eksklusif dihasilkan dari pikiran dan pengetahuan mereka sendiri, serta dapat digunakan oleh masyarakat. Pada uji K\&l di Kamerun, tim penguji menemukan bahwa $K \& l$ sangat berguna dan dapat mendorong diadakannya pertemuan-pertemuan dimana masyarakat melakukan identifikasi dan membuat urutan prioritas dalam pengelolaan hutannya dalam rangka menentukan Prinsip dan Kriteria untuk pengelolaan secara lestari.

\subsection{Mengembangkan K\&l: Beberapa langkah praktis ${ }^{24}$}

(Lihat Bab 4. Isi dari K\&l, yaitu contoh praktis P, K, I dan Penguji)

\section{Melaksanakan pekerjaan dasar}

Pada saat para stakeholder (baik yang berasal dari masyarakat sendiri atau masyarakat bersama pelaku lainnya) telah teridentifikasi, seperti yang

\footnotetext{
${ }^{24}$ Perlu dicatat bahwa CIFOR belum sepenuhnya melakukan uji pendekatan ini di lapangan, seperti dikemukakan di sini. Pendekatan dibangun berdasarkan kompilasi uji dan pengalaman di lapangan dan refleksi, dalam menyimpulkan hasil kerja CIFOR dan pelajaran yang diperoleh dari masyarakat lain serta rekan kerjanya.
} 
telah disebutkan pada bagian sebelumnya, maka perlu ditetapkan pengertian dasar untuk mengembangkan K\&l. Kesepakatan umum menyangkut tujuan dari pengelolaan hutan lestari dan komitmen untuk menggunakan K\&l sebagai suatu perangkat, harus dibuat. Hal ini dapat dilakukan melalui kombinasi diskusi antar individu dan kelompok.

\section{Mempelajari konsep dan kerangka kerja K\&I}

Langkah berikutnya adalah untuk memastikan bahwa setiap orang sudah terbiasa dan puas dengan K\&l. Pertemuan yang dihadiri oleh stakeholder harus diadakan untuk menggali konsep-konsep dan definisi K\&l, yang diuraikan pada Bagian 2 pada pedoman ini. Pastikan bahwa setiap orang mengetahui arti di balik perbedaan tingkatan antara Prinsip, Kriteria, Indikator, dan Penguji. Pada ketiga lokasi uji kita mendapatkan bahwa sebagian masyarakat tidak menemui kesulitan dalam memahami Prinsip dan Indikator, tetapi mengalami kesulitan untuk memahami Kriteria.

Telitilah hal ini sepenuhnya untuk memperoleh pemahaman seluas mungkin sebelum melakukan langkah selanjutnya.

Petunjuk: Ingatlah untuk memusatkan perhatian pada pembuatan kerangka kerja yang berguna dan dapat dipakai oleh masyarakat yang akan melakukan pemantauan dan menggunakan K\&l. Sangat penting untuk memahami arti sebenarnya dari K\&l, bukan istilahnya satu persatu. Jika partisipan merasa lebih baik bila menggunakan istilah-istilah 'ide', 'tujuan', 'indikator' atau 'tanda', dan 'informasi', atau istilah lain, maka biarkanlah mereka menggunakannya. Kuncinya adalah adanya pemahaman sepenuhnya mengenai hubungan antara berbagai tingkat - hal-hal yang dapat diukur atau dipantau ('Indikator') yang dibentuk langsung ke dalam standar proses ('Kriteria'), yang berpengaruh langsung pada suatu pernyataan yang memiliki kebenaran secara fundamental ('Prinsip'). Struktur hirarki dapat dirubah agar sesuai dengan kebutuhan masyarakat setempat, sepanjang pokok-pokok yang mendasari tetap ada. 


\section{Mengembangkan Prinsip}

Jika partisipan sudah terbiasa dengan perbedaan-perbedaan antara Prinsip, Kriteria, Indikator, dan Penguji, maka langkah selanjutnya adalah mengidentifikasi Prinsip-prinsip terpenting. Hal ini dapat dimulai dengan mengadakan diskusi untuk membahas arti dari pengelolaan hutan secara lestari bagi stakeholder yang berbeda-beda.

Masalah-masalah yang dapat dikemukakan dalam diskusi, sebagai contoh adalah:

- Seperti apa kira-kira masa depan yang ideal bagi masyarakat dan hutan?

- Apa yang menjadi elemen penting dalam visi pengelolaan secara lestari?

- Apa yang menjadi prioritas kita untuk hutan dan mayarakat kita? (Supaya perangkat K\&l ringkas dan padat.)

- Bagaimana cara kita membuat urutan berdasarkan kepentingannya?

- Bagaimana kita dapat menyatakannya sebagai Prinsip?

- Apakah mereka setuju jika memulai dari Prinsip yang telah ada? Haruskah Prinsip tersebut dimodifikasi?

Penting untuk mengingat definisi dari Prinsip yang telah diuraikan pada Bab 2 dalam pedoman ini. Tujuannya adalah untuk mendapatkan seminimal mungkin jumlah Prinsip dasar atau ide (3-4).

\section{Mengembangkan kriteria}

Langkah selanjutnya adalah mengidentifikasi sejumlah Kriteria atau 'pilar' di mana setiap Prinsip berada. Hal ini dapat dilakukan dalam pertemuan yang sama atau pertemuan berikutnya.

Masalah-masalah yang dapat diangkat, untuk setiap Prinsip adalah:

- Apa yang perlu dinilai jika Prinsip ikut menyatu?

- Bagaimana kita dapat mengenali hutan yang dikelola secara lestari? 
- Bagaimana kita mengenali suatu manajemen masyarakat yang baik?

- Bagaimana kita menyatakannya sebagai sebuah Kriteria?

- Jika dimulai dari K\&l yang telah ada, apakah kita akan memahaminya? Apakah mereka menyetujuinya? Apakah K\&l tersebut perlu dimodifikasi?

Jawaban dari pertanyaan-pertanyaan di atas dapat menjelaskan tentang hasil nyata dari praktek pengelolaan secara lestari, yaitu dengan menggambarkan aspek-aspek dari hutan atau masyarakat, atau lingkungan politik/ekonomi. Jawaban yang lain dapat menjelaskan proses yang seharusnya terjadi jika hutan dikelola menurut Prinsip. Tujuannya adalah untuk memperoleh sejumlah kecil Kriteria (3-4) untuk setiap Prinsip.

\section{Mengembangkan Indikator}

Setelah mengidentifikasi sifat-sifat dasar Kriteria yang perlu dinilai untuk setiap Prinsip, langkah selanjutnya adalah mengidentifikasi Indikator yang dipakai untuk menilai apakah Kriteria tersebut cocok. Indikator tersebut harus berupa informasi nyata yang dapat diukur dengan cara tertentu.

Pertanyaan-pertanyaan yang diajukan untuk mendukung pengembangan Indikator, adalah:

- Apa yang perlu kita ketahui untuk menilai setiap Kriteria?

- Mana yang paling penting dan dapat diukur?

- Bagaimana kita dapat menyatakannya sebagai Indikator?

- Jika mulai dari perangkat Indikator yang telah ada, Indikator mana yang dapat digunakan dan mana yang perlu diubah?

Tujuannya adalah untuk menetapkan sejumlah kecil Indikator utama (2-3) untuk setiap Kriteria yang dapat diukur atau dinilai dengan cara tertentu, agar memungkinkan penilaian Kriteria. 


\section{Mengembangkan Penguji}

Setelah mengidentifikasi Indikator, langkah penting selanjutnya adalah mengidentifikasi Penguji, yang menggambarkan data atau informasi yang diperlukan oleh Indikator.

Pertimbangkan setiap Indikator, dan ajukan pertanyaan seperti di bawah ini:

- Informasi apa yang dapat diberikan oleh begitu banyaknya data?

Apa yang perlu kita hitung, ukur, lihat, dan catat?

- Informasi apa yang dapat diberikan oleh sedikit data?

Tujuan keseluruhan adalah untuk mencoba mengembangkan perangkat minimal K\&l utama/kunci, yang cukup luas untuk mencakup seluruh masalah tapi cukup kecil untuk digunakan. Menetapkan Indikator kunci yang tepat akan mengurangi jumlah data yang harus dikumpulkan.

\section{Petunjuk :}

- Jika Anda telah mengidentifikasikan 4 Prinsip, masing-masing dengan 3 Kriteria yang memiliki 3 Indikator, maka total terdapat 36 Indikator yang harus dipantau dan dinilai. Hal ini cukup tepat sebagai upaya pertama. Jangan mencoba untuk langsung mengerjakan seluruhnya dan jangan mengharapkan untuk langsung mencapai kesempurnaan. Seperti yang Anda lihat di bawah ini, terdapat kesempatan-kesempatan lebih lanjut untuk menyaring dan memperbaiki perangkat K\&l berdasarkan pengalaman. Buatlah sesederhana mungkin.

- Supaya usaha-usaha yang dilakukan seminimal mungkin, tetaplah mengingat informasi apa saja yang telah ada dan dapat diperoleh secara terus menerus, dan kegiatan apa saja yang telah berjalan yang dapat memberikan informasi yang diperlukan. Untuk mencapai tingkat yang masuk di akal (yang sesuai dengan kebutuhan dan dapat dimasukkan ke dalam kerangka kerja), buatlah dengan berdasarkan kepada apa yang telah tersedia.

(Bagian ini mencoba untuk menjelaskan bahwa beberapa informasi yang telah dikumpulkan mungkin tidak berguna atau tidak efisien. Dapatkah dibuat se-efisien mungkin?) 


\section{Mengembangkan metode pengumpulan data untuk Penguji}

Untuk menyelesaikan tahap ini, Anda juga harus memikirkan tentang bagaimana, di mana, dan kapan data untuk Penguji tersebut dapat diperoleh. Sebagai contoh, beberapa data mungkin ditemukan melalui hasil pengamatan langsung di lapangan. Beberapa data yang lain mungkin tergantung pada hasil survei tertentu atau akses terhadap catatan-catatan yang telah tersedia. Untuk mendapatkan informasi lain, mungkin juga perlu menggunakan perangkat partisipatif atau metode penilaian. Tujuannya di sini adalah untuk menjelaskan dari mana data dan informasi tersebut diperoleh dan bagaimana cara untuk mendapatkannya. Hal ini bukan hanya memberikan panduan untuk pemakaian berikutnya, tapi juga merupakan tanda peringatan awal jika ada Penguji yang mungkin terlalu sulit atau mahal untuk diukur.

Untuk setiap Penguji, pertanyaan-pertanyaan yang berkaitan dengan metode pengumpulan data adalah :

- Di mana kita dapat memperoleh data?

- Bagaimana cara pengumpulan data tersebut?

- Seberapa sering data tersebut dikumpulkan sehingga dapat dipakai?

\section{Petunjuk:}

Untuk seluruh langkah dalam pengembangan K\&l, pastikan bahwa:

- setiap langkah memiliki sasaran yang jelas;

- $\quad$ orang tetap ingat perbedaan antara Prinsip, Kriteria, Indikator, dan Penguji, atau istilah-istilah lain yang dipakai;

- semua hal disimpan dan dicatat; dan

- ada seseorangyang bertanggung jawab dalam kelompok, yang dapat mengatur supaya kelompoknya tetap menjalankan tugasnya sesuai waktu yang tersedia, dan dapat membuat seluruh anggota kelompok ikut berpartisipasi dalam diskusi (sebagai contoh: memiliki seorang fasilitator merupakan ide yang sangat baik). 


\section{6 'Menyaring' K\&l: Apakah masing-masing merupakan yang terbaik untuk dikerjakan?}

Langkah selanjutnya adalah menyaring K\&l - yang artinya memeriksa satu persatu untuk memastikan bahwa K\&l tersebut:

- Indikator kunci - tujuannya bukan untuk mengumpulkan informasi sebanyak mungkin, tapi untuk mengidentifikasi jumlah minimum K\&l kunci yang dapat memberikan cukup informasi untuk menilai kemajuan ke arah sasaran yaitu pengelolaan hutan secara lestari. Apakah perangkat K\&l tersebut dapat memberikan apa yang anda inginkan?

- Mudah untuk mengenali, menyimpan dan menafsirkan artinya, dengan biaya yang terjangkau, Anda akan merasa puas dengan biaya yang terjangkau bila $K \& l$ yang dibuat dapat digunakan dan pengumpulan data dapat dipraktekkan, serta informasi dapat disimpan dengan cara tertentu sehingga dapat dinilai atau ditafsirkan. Dapatkah Anda melakukannya dengan kemampuan yang anda miliki atau melakukannya dengan wajar? Dapatkah anda menjalankan metode tersebut? Seperti yang telah diuraikan di atas, apakah anda meminimalkan usaha dengan menambah latihan atau kegiatan yang telah berjalan, selama kegiatan tersebut masuk akal dan berguna?

- Dapat dipercaya - penting untuk merasa yakin bahwa $\mathrm{K} \& \mathrm{l}$ yang terpilih akan memberikan informasi yang konsisten dan terpercaya. Apakah 2 orang akan mendapatkan jawaban yang sama jika menggunakan $\mathrm{K} \& \mathrm{l}$ yang sama dengan lokasi yang sama pula?

Karena K\&l dikembangkan untuk dipakai oleh suatu masyarakat, maka sangatlah perlu untuk memastikan bahwa K\&l tersebut:

- sedapat mungkin telah disetujui oleh sebagian besar stakeholder dalam masyarakat;

- mudah dipahami oleh anggota masyarakat;

- sesuai dengan keahlian masyarakat; dan

- efektif dalam waktu. 
Jika suatu kelompok menilai bahwa Prinsip, Kriteria, Indikator, dan Penguji tidak layak untuk melalui tahap penyaringan, maka inilah saat yang tepat untuk mencari alternatif lain.

\subsection{Uji pertama: Melaksanakan penaksiran K\&l secara cepat}

Sebelum mengembangkan rencana penaksiran dan pemantauan lengkap serta menempatkan K\&l agar siap digunakan di lapangan (bagian 3.8), satu langkah tepat berikutnya adalah menguji kegunaan K\&l. Caranya adalah menggunakan $\mathrm{K} \& \mathrm{l}$ yang telah dikembangkan dengan segera sebagai dasar pelaksanaan penilaian secara cepat. Kegunaannya adalah:

- memperkenalkan perangkat sementara K\&l kepada sebagian besar stakeholder;

- dapat memperlihatkan kesenjangan, ketidak-konsistenan, dan salah pengertian mengenai perangkat K\&l; dan

- memperlihatkan sampai sejauh mana stakeholder mampu mengerjakannya sebelum pemantauan yang sesungguhnya dimulai.

Penaksiran cepat dapat dilakukan dengan cara mencatat seluruh Indikator di atas kertas, dan pada setiap Indikator dicantumkan pertanyaan: 'bagaimana keadaan kita'. Apakah jawabannya 'baik', 'buruk', atau 'biasa saja', dapat dicatat dengan tanda-tanda yang sederhana, seperti misalnya sebuah gambar bulan purnama untuk jawaban 'baik', bulan muda untuk 'buruk', dan bulan sabit untuk jawaban 'biasa saja'. Alternatif lain "penilaian" dengan menggunakan warna - hijau untuk 'baik', merah untuk 'buruk', dan kuning untuk 'biasa saja'. Untuk beberapa Indikator, yang membutuhkan pengukuran atau pemantauan dalam jangka waktu tertentu, maka Anda diperkenankan melakukan estimasi atau perkiraan. Pemantauan yang akurat dapat dilakukan kemudian. Pada tahap ini anda hanya mencoba untuk memperoleh suatu gambaran menyeluruh mengenai kondisi yang dihadapi. 
Ini merupakan kesempatan baik untuk berpartisipasi. Mungkin akan sangat memudahkan bila beberapa kelompok dari bermacam-macam orang dalam suatu masyarakat ikut melakukan penaksiran seperti di atas secara terpisah, kemudian hasilnya diperbandingkan. Harus dijelaskan bahwa penaksiran ini bertujuan untuk mencari gagasan mengenai bagaimana cara untuk memperbaiki keadaan, oleh karena itu Indikator yang tidak mendapat peringkat tinggi janganlah dilihat sebagai masalah melainkan sebagai suatu kesempatan untuk memperbaiki.

Beberapa cara sederhana untuk mendapatkan suatu pandangan umum mengenai 'peringkat kelestarian' antara lain:

- Dimulai dengan penaksiran cepat yang Anda lakukan, berikan nilai 3 untuk gambar bulan purnama, nilai 2 untuk bulan sabit, dan nilai 1 untuk bulan muda.

- Jumlahkan seluruh nilai Indikator untuk setiap Kriteria, kemudian dibagi dengan jumlah seluruh Indikator dalam Kriteria tersebut. Tetapkan hasil perhitungan untuk Kriteria yang bersangkutan.

- Jumlahkan nilai dari setiap Kriteria dalam masing-masing Prinsip, kemudian dibagi dengan jumlah seluruh Kriteria yang ada dalam Prinsip tadi. Tetapkan hasil perhitungan untuk Prinsip yang bersangkutan.

(Anda juga dapat melakukan penilaian seperti di atas pada tingkat Prinsip untuk mendapatkan peringkat 1 sampai 3. Jumlahkan seluruh nilai Prinsip kemudian dibagi dengan jumlah Prinsip. Tetapi, cara yang sangat sederhana ini tidak begitu banyak berarti. Bagaimanapun juga, hal tersebut akan menunjukkan indikasi (yang sangat sederhana), mengenai seberapa dekat anda dalam mencapai tujuan secara keseluruhan dari pengelolaan secara lestari. ${ }^{25}$

\footnotetext{
${ }^{25}$ Yang lebih tajam tetapi pendekatannya rumit adalah mengukur masing-masing elemen. Lihat publikasi Toolbox CIFOR "The Score guide", dan "The MCA Manual” untuk pemahaman lebih luas. (Salim et al., 1999 dan Mendoza et al. 1999).
} 
Hal yang paling penting dan harus diperhatikan di sini adalah membuat perbandingan antara Prinsip, Kriteria, dan Indikator, untuk menyoroti seluruh aspek apakah telah dikerjakan dengan benar, dan hal apa saja yang perlu diperbaiki. Apakah terdapat suatu kecenderungan atau pola? Mengapa kecenderungan atau pola tersebut harus diperhatikan?

\section{Tindakan yang harus segera diambil berdasarkan hasil penaksiran cepat}

Pertama, bentuklah berdasarkan kecenderungan dan pola yang telah digali di atas dan diskusikan mengenai sebab-sebab pokok yang harus dibicarakan. Diskusikan mengenai tindakan apa saja yang layak diambil untuk meningkatkan peringkat dari yang semula bertanda bulan muda atau bulan sabit menjadi bulan purnama? (Kadang-kadang gagasan yang bagus mengenai 'praktek yang baik' pada kenyataannya menjadi dasar pembentukan K\&l). Untuk setiap kegiatan yang diusulkan, tetapkan apakah harus dilakukan, siapa yang akan mengerjakan, dan bagaimana.

Kedua, kembali ke perangkat K\&l anda dan pertimbangkan apakah penaksiran cepat tersebut menunjukkan adanya masalah dalam $K \& l$ itu sendiri, seperti misalnya istilah-istilah yang tidak jelas artinya atau aspek-aspek yang tidak dapat diukur. Jika terdapat masalah seperti itu, segera buatlah perbaikan sebelum mulai melakukan pemantauan jangkapanjang.

\subsection{Pemantauan: Pelaksanaan K\&l di lapangan}

Langkah selanjutnya adalah meletakkan K\&l dalam kerangka kerja, melalui perencanaan dan penerapan sistem pemantauan K\&l yang dapat memberikan umpan balik kepada sistem manajemen. Sebagian besar K\&l digunakan oleh lembaga pemberi sertifikat hasil hutan sebagai kerangka kerja, untuk menaksir apakah hasil hutan tersebut berasal dari hutan yang dikelola secara lestari. Penaksiran tersebut sering kali dilakukan secara formal, dan pada kasus tertentu dilakukan dengan 
sangat teliti, menyangkut pengumpulan dan analisa data kuantitatif yang sangat banyak. Penaksiran ini hampir selalu dikerjakan oleh badan pemberi sertifikat profesional yang berasal dari pihak luar. Di sini kita mengusulkan sistem penaksiran yang lebih sederhana dan mudah digunakan, dan yang lebih penting adalah keikutsertaan anggota masyarakat (partisipatif).

Di bawah ini adalah serangkaian langkah yang diusulkan dalam penggunaan K\&l untuk membantu menjamin pengelolaan hutan secara lestari. Tidak seluruh langkah akan sesuai dengan semua situasi, tetapi langkahlangkah ini akan memberikan gagasan untuk mencapai kemajuan dan mengembangkan K\&l.

Langkah-langkah di bawah ini membentuk suatu lingkaran atau siklus yang terdiri dari perencanaan, tindakan, pemantauan, penaksiran, dan proses belajar, yang dilakukan oleh masyarakat dalam suatu proses yang berkesinambungan (dengan harapan adanya peningkatan).

\section{Langkah 1: Membuat suatu rencana pemantauan}

Anda perlu menciptakan suatu rencana pemantauan untuk mengatur langkah selanjutnya, sehingga semua orang yang terlibat mengetahui apa yang akan terjadi. Untuk setiap Penguji ${ }^{26}$ diajukan pertanyaan sebagai berikut:

- Kapan Penguji dipantau?

- Siapa yang melakukan?

- Kapan dilakukan?

- Bagaimana melakukannya?

- Siapa yang bertanggung jawab untuk mengumpulkan hasilnya?

- Bagaimana hasil-hasil tersebut dicatat?

- Kapan penaksiran akan dibuat?

- Sumber daya apa yang dibutuhkan (waktu, uang, alat-alat atau perlengkapan lain, atau akses untuk mendapatkan informasi)?

\footnotetext{
${ }^{26}$ Seperti telah disebutkan terdahulu, pada beberapa kasus, terdapat tumpang-tindih langsung antara Indikator dan Penguji. Jika hal ini terjadi, tentu langkah ini akan muncul pada tingkat indikator yang tepat.
} 
Untuk setiap Indikator, cobalah untuk tetap menjaga kebutuhan informasi sesederhana mungkin. Cobalah untuk membagi tanggung jawab atas pemantauan tersebut secara merata dalam masyarakat dan antara partner. Hal ini menyangkut lebih banyak orang dan dapat mengurangi beban kerja bagi semua orang yang terlibat. Berdasarkan pengalaman, pengetahuan tidak tersebar secara merata di antara seluruh stakeholder. Carilah siapa yang paling banyak memiliki pengetahuan mengenai berbagai macam aspek yang terdapat pada K\&l. Ajaklah mereka ikut bertanggung jawab untuk memantau informasi.

Jangan lupa: sedapat mungkin, pemantauan harus dibangun berdasarkan keahlian yang ada dan berdasarkan kegiatan formal dan informal dalam masyarakat.

Pikirkan mengenai waktu secara keseluruhan. Kapan pertama kali akan dilakukan program pemantauan dan penaksiran? Apakah Anda akan melaksanakan latihan pemantauan dengan segera? Kapan hasil perdananya secara keseluruhan akan selesai? Apakah Anda menetapkan suatu program pemantauan yang dapat berlangsung selama beberapa tahun?

Anda harus merencanakan untuk membawa seluruh informasi yang telah terkumpul. Hal ini sangat penting. Siapa yang akan bertanggung jawab dalam menyatukan seluruh hasil? Apakah yang bertanggung jawab tersebut merupakan perorangan atau suatu kelompok? Apakah semua orang yang terlibat dalam pemantauan mengerti bagaimana memberikan informasi kepada orang atau kelompok yang ditunjuk tersebut? Kapan mereka harus menyediakan informasi tersebut? Apakah semua orang dengan senang hati bersedia menyediakan informasi untuk orang atau kelompok ini? Jika tidak, mungkin Anda harus memikirkan kembali siapa yang sebaiknya ditunjuk. Apakah merupakan anggota masyarakat, dan jika bukan, adakah alasan yang tepat mengapa orang atau kelompok tersebut bukan anggota masyarakat? Rasa memiliki masyarakat terhadap proses Pemantauan sangatlah penting. Menyimpan informasi di dalam lingkup masyarakat 
setempat membuat informasi tersebut lebih siap tersedia dan kemungkinan besar lebih mudah digunakan, dibanding jika disimpan di kantor yang jauh letaknya. Kami menganjurkan bahwa jangka waktu yang diperlukan sejak di mulainya pemantauan hingga pengumpulan informasi tidak lebih dari 1 tahun.

Perhatikan kebutuhan akan sumberdaya secara keseluruhan. Apakah sumberdaya tersebut telah tersedia, atau dapat disediakan? Jika tidak, maka perencanaan anda harus disesuaikan.

Mungkin merupakan ide yang baik untuk membuat jadwal yang menunjukkan dengan jelas kapan pemantauan akan dilaksanakan. Sebagian pemantauan mungkin pelaksanaannya perlu disebar selama jangka waktu pemantauan. Sebagian yang lain dapat dikelompokkan secara bersama-sama pada waktu tertentu. Identifikasi siapa yang akan melakukan dan apa yang akan dilakukan. Harus jelas kapan seluruh informasi akan dikumpulkan, siapa yang mengumpulkannya, dan kapan penaksiran berikutnya akan dilaksanakan. Pastikan bahwa setiap orang dalam masyarakat mengetahui hal ini.

\section{Langkah 2: Menyusun rencana penaksiran}

Anda juga perlu merencanakan tahap penaksiran.

- Bagaimana hasil pemantauan akan digunakan?

- Siapa yang akan melaksanakan penaksiran?

- Bagaimana menjaga supaya proses dan hasilnya selalu transparan dan mudah diperoleh seluruh masyarakat?

- Bagaimana hasil penaksiran tersebut disampaikan kepada stakeholder?

- Keputusan seperti apa yang akan dibuat dari hasil tersebut?

- Siapa yang membuat keputusan? Bagaimana menjaga supaya proses berlangsung adil dan melibatkan partisipasi masyarakat?

- Siapa yang akan memutuskan mengenai tindakan yang harus diambil untuk menindaklanjuti hasil penaksiran? 


\section{Langkah 3: Pemantauan}

Setelah perencanaan disetujui, harus segera dilaksanakan - lakukanlah!

\section{Langkah 4: Menilai hasil pemantauan}

Pada waktu yang telah disetujui, seluruh hasil pemantauan harus terkumpul secara bersamaan. Kumpulkan para pemantau dan/atau sekelompok stakeholder kunci untuk melaksanakan penilaian, dan membuat catatan akurat dari hasil-hasil tersebut (tidak hanya berupa angka, tetapi juga permasalahan kunci yang muncul dalam diskusi). Gunakan sistem penilaian sederhana yang digunakan pada penaksiran cepat yang pertama, atau suatu sistem yang telah dimodifikasi sedemikian rupa berdasarkan pengalaman Anda. Jika sistem skoring yang digunakan adalah sistem baru atau yang telah dimodifikasi, dapatkah Anda membuat suatu perbandingan dengan penaksiran sebelumnya? Hal ini merupakan masalah yang penting untuk dipertimbangkan setiap kali penilaian dibuat.

Kemungkinan lain pada tahap ini adalah mengadakan latihan lain yang melibatkan keikutsertaan seluas mungkin kelompok stakeholder. Ajak mereka untuk menilai indikator dengan menggunakan sistem penilaian yang sama dengan sistem yang digunakan untuk pemantauan. (Seperti melakukan penaksiran cepat; tujuannya adalah untuk menawarkan gambaran lain dan untuk memberikan umpan balik pada K\&l ). Bandingkan hasil dari latihan ini dengan hasil yang diperoleh tim pemantauan. Apakah terdapat perbedaan? Sangat baik untuk saling bertukar pengetahuan dan pengalaman, serta mendiskusikan perbedaan pendapat. Hal ini dapat memperlihatkan masalah yang ada dalam metode pemantauan, sehingga Anda dapat mengubah proses tersebut di kemudian hari.

Beberapa pertanyaan yang dapat diajukan berkaitan dengan proses penilaian, adalah:

- Bagaimana gambaran secara keseluruhan mengenai kelestarian? Secara umum terlihat positif, negatif, atau diantara keduanya (pertengahan)? 
- Dapatkah anda melihat adanya suatu pola atau kecenderungan mengenai di mana letak kekuatan atau kelemahannya? Mengapa terdapat kekuatan atau kelemahan tersebut?

- Adakah hal tertentu yang bersifat kritis atau mengkhawatirkan? Atau sesuatu yang positif? Mengapa?

- Jika anda mengerjakan penaksiran cepat terlebih dahulu, bagaimana cara membandingkannya? Hal-hal apa yang tidak berubah dan apa saja yang mengalami perubahan? Apa saja yang berubah ke arah lebih baik, dan mana yang berubah ke arah lebih buruk?

- Melihat pada tingkat Kriteria atau Indikator - mengapa masingmasing mendapat peringkat seperti itu? (Mengapa mengalami perubahan sejak penilaian yang terakhir?) Faktor-faktor apa yang ada di bawah pengaruh masyarakat dan/atau mitra yang mempengaruhi penilaian atau perubahan? Faktor-faktor apa yang sekarang ada di luar pengaruh masyarakat atau mitra? Apakah sebab perubahan tidak diketahui? Adakah cara untuk mencari tahu?

\section{Petunjuk :}

- 'Negatif' pada proses penilaian bukan berarti 'gagal' - hal tersebut merupakan kesempatan untuk belajar.

- 'Sukses' juga merupakan kesempatan untuk belajar - dan jangan lupa untuk memberi selamat kepada mereka. Adakah cara dalam masyarakat atau mitra untuk menghargai kemajuan mereka sendiri?

- Jangan lupa untuk membuat catatan yang jelas dan terperinci mengenai penilaian tersebut sehingga dapat dimengerti oleh orangorangyang tidak hadir dalam diskusi. Edarkan catatan tersebut kepada anggota masyarakat setempat atau stakeholder yang tidak terlibat secara langsung dalam penilaian. 
Satu cara yang paling bermanfaat untuk menampilkan hasil penilaian secara visual adalah dengan menggunakan 'Diagram Sarang Laba-laba' (lihat Gambar 2) ${ }^{27}$. Diagram ini menciptakan suatu kesan seperti sarang laba-laba, atau sebuah roda sepeda dengan jari-jarinya. Setiap jari-jari diberi judul yang diambil dari perangkat $K \& l$ (biasanya dari tingkat Kriteria). Dengan asumsi bahwa titik pusat nilainya 0 (yaitu, sangat buruk), dan di bagian tepi luar nilainya 10 (baik sekali), maka nilai perkiraan dari setiap Kriteria dapat dipetakan di atas jari-jari atau sarang laba-laba tersebut. Jika sebuah garis ditarik untuk menghubungkan seluruh nilai maka akan muncul suatu gambaran yang menunjukkan kecenderungan daerah yang kuat dan yang lemah. Hal ini tidak hanya berguna dalam penilaian perorangan, tapi juga sangat berguna untuk memberikan gambaran tentang perubahan kecenderungan kelestarian dari waktu ke waktu jika proses ini diulangi setiap tahun.

Gambar 2. Contoh Diagram Sarang Laba-laba

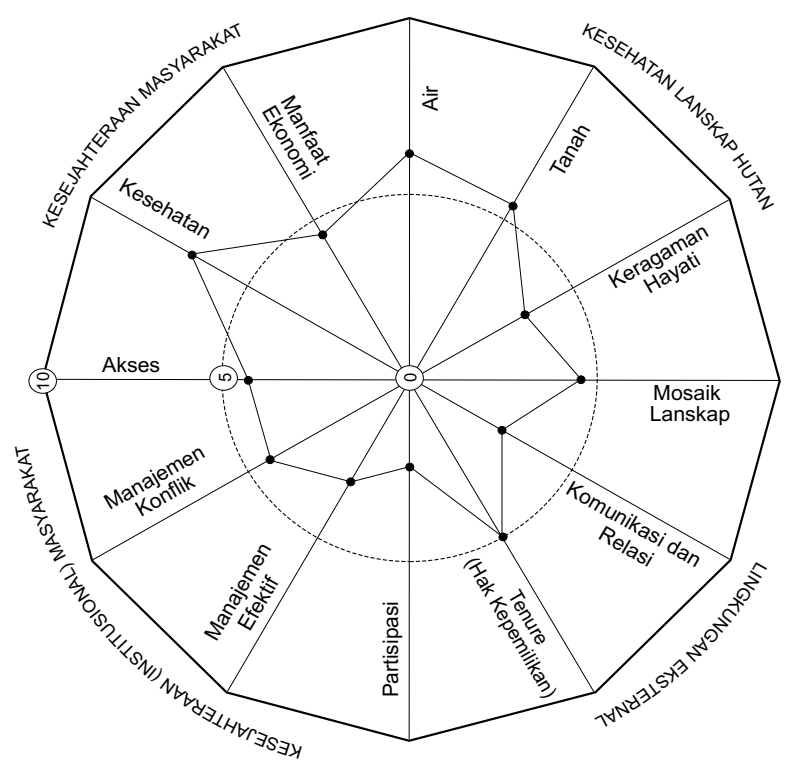

${ }^{27}$ Pencantuman dari alat ini diilhami oleh "Poligon-poligon Kelestarian" yang ditemukan dalam Herweg et al. (1998) dan oleh prestasi dari proyek-proyek seperti "the Nepal-Australia Community Resource Management Project "dan" the Nepal - UK Community Forest Project" dalam bidang ini. 


\section{Langkah 5: Rencana Kegiatan baru}

Menyusun suatu perencanaan pengelolaan yang baru sebenarnya terkait erat dengan tahap penilaian sebelumnya - bahkan dapat dilakukan pada pertemuan yang sama atau dalam beberapa pertemuan. Rencana pengelolaan ini seharusnya dibangun berdasarkan hal-hal yang dipelajari selama proses penaksiran. Secara khusus, hal tersebut merujuk pada hubungan antara kegiatan manajemen di masa lalu dan masa sekarang yang dijalankan oleh masyarakat dan mitra lain dalam penilaian (lihat pertanyaan terakhir pada langkah 4), dan pertimbangkan penyesuaian atau perubahan apa yang dapat dilakukan di masa depan.

Sekali lagi, pada tingkat Kriteria (atau Indikator, jika berjalan lebih baik), apakah penilaian tersebut atau kelompok manajemen mempertimbangkan secara terperinci penilaian hasil tersebut dalam kaitannya dengan kegiatan manajemen (atau bukan kegiatan). Jika Anda memiliki waktu terbatas, atau memiliki K\&l terlalu banyak, Anda harus memberikan prioritas kepada $K \& l$ yang paling penting dalam sebuah kelompok diskusi.

Beberapa pertanyaan yang dapat membantu dalam proses belajar:

- Kegiatan pengelolaan (atau bukan kegiatan) apa yang mempengaruhi Kriteria atau Indikator?

- Apakah ada kaitan langsung antara tindakan dan akibat yang terjadi (misalnya, apa pengaruh dari aktivitas pengelolaan yang dianggap 'positif' atau 'negatif')? Apakah terdapat masalah yang muncul dengan tiba-tiba? Mengapa?

- Apakah ada kesenjangan pengetahuan untuk memahami segala sesuatu yang terjadi? Bagaimana hal tersebut dihadapi ?

- Dengan memperhitungkan hal-hal di atas, apakah kegiatan pengelolaan oleh masyarakat setempat di masa lalu harus diteruskan atau diubah? Apakah ada kegiatan/tindakan baru yang dapat diambil untuk mengangkat masalah yang diperlihatkan oleh Indikator, seperti rendahnya prestasi atau penurunan prestasi? 
- Apakah ada gagasan baru untuk dilakukan, yang merupakan hasil dari pemantauan dan penilaian? Bagaimana hal tersebut dapat dilakukan?

- Hal apa lagi yang dapat berpengaruh (selain pengelolaan setempat)? Apakah ada pegaruh dari luar yang berakibat negatif bagi kelestarian, dan dapatkah pengaruh negatif tersebut, diatasi? Jika hal tersebut dahulu di luar pengaruh kelompok, apakah keadaannya sampai sekarang masih seperti itu? Adakah sesuatu yang harus dilakukan supaya pengaruh dari luar tersebut menjadi sesuatu yang positif?

\section{Langkah 6: Memodifikasi perangkat K\&I}

Perangkat K\&l yang asli bukan merupakan sesuatu yang keramat - harus hidup, tumbuh, berubah, dan berkembang, untuk mencerminkan pengetahuan masyarakat dan juga mencerminkan perubahanperubahan yang terjadi pada daerah tersebut dan lingkungan.

Ada beberapa perangkat K\&l yang tidak begitu bermanfaat. Ada yang terlalu sulit dipantau, atau hasilnya memiliki arti ganda, atau ada yang mengangkat masalah yang sudah dipecahkan. Jika hal tersebut terjadi, buanglah!

Kadang-kadang timbul gagasan yang dapat dijadikan Indikator baru atau menjadi pengganti. Indikator baru tersebut juga dapat mengisi kekosongan yang kadang terjadi. Jika hal tersebut terjadi, masukkan!

Beberapa K\&l mungkin perlu disesuaikan atau dimodifikasi. Jika hal tersebut terjadi, lakukan perubahan!

Secara keseluruhan, Anda mungkin memiliki terlalu banyak Indikator. Jika hal itu terjadi, anda dapat memakai penyaring yang telah digunakan selama tahap pengembangan untuk mengurangi jumlah perangkat $K \& l$ atau melakukan rangking untuk memilih mana yang paling penting. Kita mengetahui bahwa proses merubah perangkat K\&l merupakan cara yang baik untuk berbagi ilmu pengetahuan, karena diperlukan banyak 
diskusi dan adu argumen tentang mengapa harus dilakukan perubahan. ${ }^{28}$

\section{Langkah 7: Kembali ke Langkah 1}

K\&l digunakan dalam suatu spiral atau lingkaran yang terus-menerus, yang terjadi dari refleksi, perencanaan, tindakan, dan pengamatan.

Gambar 3. Spiral pemantauan (juga Lingkaran Proses Belajar)

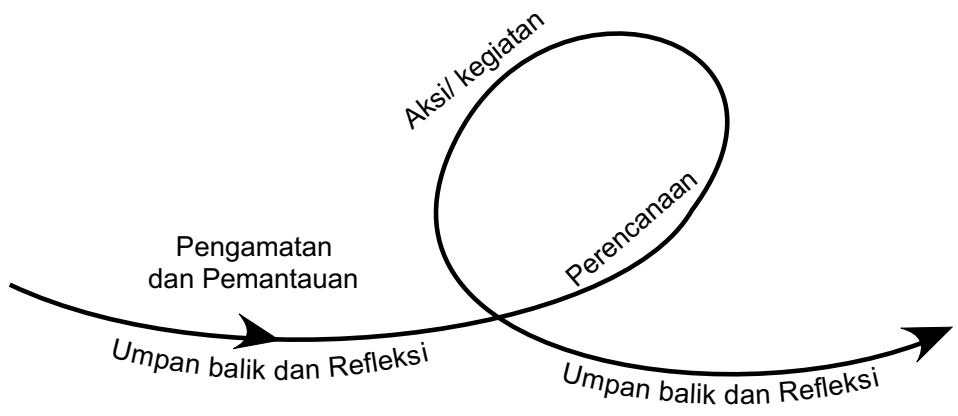

${ }^{28}$ Perlu dicatat bahwa CIFOR telah menciptakan peralatan dasar dalam komputer yang disebut CIMAT untuk membantu melakukan modifikasi dan adaptasi perangkat umum CIFOR tentang K\&I untuk Unit Pengelolaan Hutan. Perangkat ini belum diadaptasikan pada perangkat K\&I PHM dan belum dilakukan uji lapangan dengan proses yang partisipatif, tetapi jika perangkat ini merupakan perangkat dasar dan Anda memiliki akses terhadap fasilitas komputer, maka Anda dapat mencobanya. Lihat bagian bahan acuan untuk informasi. 


\section{Isi K\&I}

\section{Menyajikan K\&l yang terpilih dari tiga lokasi uji CIFOR}

Bagian ini membahas isi K\&l yang dikembangkan di lokasi uji CIFOR. Yang akan ditampilkan adalah K\&l yang terpilih dari tiga lokasi yang uji (K\&l tersebut menampilkan serangkaian contoh yang saling berhubungan dan terkombinasi, bukan merupakan perangkat tunggal $K \& l)$, untuk menggambarkan sampai sejauh mana permasalahan dan $K \& l$ yang dianggap penting di ke tiga lokasi uji. $K \& l$ ini ditampilkan sebagai titik awal untuk pengembangan $\mathrm{K} \& l$ lebih lanjut pada tingkat lokal - untuk membangun gagasan dalam mencari permasalahan yang sesuai dalam konteks yang lebih tepat. K\&l tersebut tidak dapat dilihat sebagai satu paket K\&l yang umum atau yang pasti untuk PHM. Beberapa K\&l dapat diterapkan di sebagian besar lokasi PHM, beberapa lainnya memerlukan lokasi yang lebih khusus, tetapi mungkin dapat disesuaikan dengan lokasi lain. Ada beberapa K\&l yang tidak relevan sama sekali dan harus dibuang, dan beberapa K\&l yang khusus untuk lokasi lainnya mungkin saja hilang. Sesuaikan!

Harus diingat bahwa $K \& l$ ini dikembangkan oleh tim ilmuwan ahli dari disiplin ilmu ekologi, manajemen hutan dan sosial ekonomi. Sementara seperangkat K\&l yang dikembangkan oleh tim dimodifikasi berdasarkan tanya jawab dengan masyarakat lokal di lokasi uji dengan memperhatikan kondisi lokasi wilayah setempat, namun $\mathrm{K} \& \mathrm{I}$ tersebut bukan merupakan hasil kerjasama penuh seperti yang direkomendasikan dalam pedoman ini (cara kerja CIFOR adalah belajar dari pengalaman). Sebagai hasilnya, beberapa $\mathrm{K} \& \mathrm{l}$ cenderung tetap memakai bahasa ilmiah, dan disajikan dalam bahasa yang sulit dimengerti bagi anggota masyarakat yang tinggal di hutan. Terlepas dari masalah bahasa, hal-hal yang disajikan merupakan indikasi yang baik bagi masalah yang dianggap penting untuk

${ }^{29}$ Daftar lengkap seluruh K\&l yang dihasilkan di lokasi-lokasi uji CIFOR dapat diperoleh dari CIFOR. Lihat bagian bahan acuan. 
kelangsungan PHM dan merupakan titik awal yang baik dalam kerangka K\&l.

Tim penguji menemukan beberapa kesulitan dalam mengelompokkan K\&l berdasarkan prinsip-prinsip ekologi, manajemen hutan, dan sosial ekonomi. Sebagai contoh, di satu sisi K\&l yang serupa dikelompokkan ke dalam ekologi, tapi di sisi lain juga dikelompokkan ke dalam manajemen hutan. Hal ini terjadi karena strategi pengelompokkan $\mathrm{K} \&$ yang berdasarkan prinsip ekologi, manajemen hutan, dan sosial ekonomi memperlihatkan sudut pandang ilmuwan secara top-down terhadap K\&l, dan semula dikembangkan untuk manajemen hutan industri. Pandangan ini mungkin tidak dapat menangkap adanya perbedaan, kerumitan, dan faktor-faktor yang saling berhubungan menyangkut kelangsungan PHM, dan mungkin gagal dalam menggambarkan persepsi dari banyaknya masyarakat yang bergantung pada keberadaan hutan.

Sebagai hasilnya, untuk mencapai tujuan yang dimaksudkan dalam pedoman ini dan kepentingan pekerjaan di masa yang akan datang yang berkaitan dengan K\&I PHM, kami diberi tugas untuk melakukan pengelompokan ulang $\mathrm{K} \& \mathrm{l}$ berdasarkan pokok-pokok yang mencakup arti luas yang diwujudkan ke dalam 4 (empat) pedoman prinsip/dasar untuk menjaga kelangsungan PHM. Hal ini akan dapat dimengerti oleh masyarakat dan mungkin akan menjadi titik awal yang tepat untuk menghasilkan gambaran di lokasi yang bersangkutan dan prinsip-prinsip yang disepakati dalam mendukung K\&l.

Empat prinsip ${ }^{30}$ yang disarikan dari lokasi di lapangan yaitu:

- Kesejahteraan masyarakat (kelembagaan) terjamin

- Kesejahteraan rakyat terjamin

\footnotetext{
30 Prinsip ini muncul sebagai payung logika menyangkut penelitian dan $K \& l$ yang telah berkembang selama uji K\&l PHM; hal ini bukan semata-mata cara pengorganisasian Prinsipprinsip Hutan yang dikelola oleh masyarakat. Seperti telah dikemukakan sebelumnya, prinsip harus diperoleh melalui proses yang partisipatif, dan berdasarkan pada persepsi, kebutuhan dan pilihan para pengguna.
} 


\section{- Kesehatan lanskap hutan terjamin}

\section{- Lingkungan eksternal mendukung PHML}

Ada penjelasan singkat untuk masing-masing prinsip di atas yang diikuti oleh beberapa kelompok K\&l. Setiap kelompok K\&l ditandai dengan satu judul yang diberi garis bawah. Untuk setiap kelompok, pertama-tama berisi pernyataan singkat yang mendukung, kemudian diikuti oleh contoh K\&l dari lokasi uji lapangan. ${ }^{31}$

Pada contoh yang diberikan, tulisan yang dicetak tebal adalah kriteria. Tulisan yang dicetak miring adalah indikator. Sedangkan penguji dicetak normal.

\section{Perlu dicatat.}

1) Maksud dari $\mathrm{K} \& \mathrm{I}$ ini tidak hanya untuk menyediakan contoh yang sebenarnya dari PHM K\&l, tetapi juga untuk menggambarkan persamaan dan perbedaan K\&l di lokasi yang berbeda. Harap diingat bahwa kita tidak menyajikan satu perangkat $K \& l$ yang bertalian atau K\&l pengganti - kita menawarkan prinsip-prinsip dan beberapa contoh kriteria untuk tema yang sama, masing-masing dengan indikator dan penguji tersendiri.

2) Penomoran contoh $K \& l$ yang terpilih mengacu pada perangkat $K \& l$ yang diambil untuk uji lapangan -- bukan mengacu pada perangkat format yang tersusun ini; dan dengan demikian penomoran harus diabaikan (kecuali referensi dibuat untuk perangkat penuh K\&l yang dibuat di lokasi uji CIFOR ${ }^{32}$ ).

\footnotetext{
${ }^{31}$ Perlu dicatat bahwa beberapa K\&l yang ada dalam contoh-contoh ini dikembangkan oleh orang yang memakai bahasa Inggris sebagai bahasa kedua, dan sebagian lainnya telah diterjemahkan ke dalam bahasa Inggris. Untuk mempertahankan arti K\&l yang sebenarnya, terjemahan diupayakan sedekat mungkin dengan susunan asli, meskipun kadang-kadang secara teknis struktur bahasa Inggris kurang tepat. Pada kasus-kasus lainnya, perangkatnya tidak lengkap, atau saran yang dianjurkan dalam pedoman ini tidak mengikuti saran yang dianjurkan dalam pedoman ini. Sekali lagi, maksud nya disini adalah hanya untuk memberikan gambaran yang mungkin terjadi dan contoh yang dikemukakan harus cukup jelas.

${ }^{32}$ Susunan lengkap K\&l ketiga lokasi uji CIFOR dapat diperoleh di CIFOR. Lihat bagian bahan acuan.
} 


\section{Prinsip 1. Kesejahteraan masyarakat terjamin}

Dalam mengembangkan $\mathrm{K} \& \mathrm{l}$ untuk kesejahteraan suatu masyarakat, masalah utama adalah menyangkut kemampuan masyarakat tersebut untuk mengelola dan mengatur fungsi ganda yaitu penggunaan dan manfaat hutan secara kolektif, sehingga manfaatnya dapat terbagi rata untuk perorangan, rumah tangga maupun kelompok, yang pada akhirnya sumberdaya hutan dapat menghasilkan kegunaan dan manfaat untuk masa depan.

Banyak penelitian yang dilakukan baru-baru ini menyangkut keberhasilan atau kegagalan PHM yang menyoroti betapa pentingnya kemampuan masyarakat dalam mengatur, mengembangkan, dan menjalankan aturan manajemen. terutama dalam menghadapi tekanan jumlah penduduk, penurunan jumlah dan kualitas sumberdaya, serta persaingan dengan masyarakat di luar. Kemampuan masyarakat untuk mengelola, mengembangkan peraturan manajemen dan menjalankannya, serta mengelola wilayah yang telah diakui secara de jure merupakan faktor yang amat penting dalam mendukung pengelolaan hutan lestari.

Di ke tiga lokasi uji, K\&l dikembangkan untuk menghadapi isu tersebut di atas. Sebagai titik awal/acuan untuk kegunaan dimasa mendatang untuk situasi PHM lainnya, dan untuk membandingkan diantara lokasi uji maka kami mengelompokkan masalah-masalah tersebut ke dalam judul-judul seperti berikut.
a. Lembaga/organisasi masyarakat dan partisipasi
b. Mekanisme pengelolaan lokal (norma, peraturan, undang- undang, dII)
c. Manajemen konflik
d. Kewenangan untuk mengelola (status kepemilikan) 


\section{1.a Lembaga/organisasi masyarakat dan partisipasi}

Untuk mengatur 'penawaran dan permintaan' sumberdaya hutan masyarakat - termasuk pembagian hak dan kewajiban, kerjasama, dan perlindungan hutan - kebanyakan sistem PHM setempat mengembangkan beberapa bentuk organisasi masyarakat. Organisasi serupa didirikan untuk membantu masyarakat untuk memusatkan perhatian pada pengembangan dan pelaksanaan peraturan melalui sistem insentif, persuasif atau penegakan sangsi. Keberadaan organisasi masyarakat yang kuat sangat penting demi kelangsungan PHM. Di dua dari tiga lokasi uji lapangan (Brazil dan Indonesia), partisipasi yang luas dalam pengambilan keputusan, termasuk partisipan wanita, merupakan masalah penting bagi kelangsungan organisasi setempat dan untuk mengurangi kemungkinan timbulnya pertentangan (konflik).

Brazil

\subsection{Masyarakat berpartisipasi dan memantau seluruh proses} perencanaan setiap sistem manajemen yang akan dilaksanakan di dalam kawasan agroforestry yang terkena dampak.

6.4.1 Partisipasi aktif masyarakat dalam konsepsi dan pemantauan sistem pengelolaan sumber agroforestry.

6.4.1.a (Persepsi bahwa) Kepemimpinan dalam suatu masyarakat diwakili oleh seluruh kelompok dan golongan di dalam masyarakat.

6.4.1.b Mayoritas penduduk dewasa memiliki pengetahuan sistem manajemen dan menyetujui sistem tersebut.

6.6.1 Masyarakat memiliki bentuk-bentuk organisasi inter (antar) dan intra (di dalam) masyarakat.

6.6.1.a Diakuinya keberadaan organisasi (secara sah dan 'defacto').

6.6.1.c Partisipasi pribadi dan bersama para anggota masyarakat di dalam asosiasi, perserikatan, dan organisasi-organisasi politik. 
6.6.2 Partisipasi aktif kaum perempuan dalam diskusi dan pengambilan keputusan yang berkaitan dengan kesejahteraan masyarakat.

6.6.2.a Keberadaan perkumpulan/ organisasi yang membahas masalah-masalah yang berkaitan dengan gender

6.6.2.b Keterwakilan kaum perempuan dalam asosiasi inter dan intra masyarakat.

Kamerun

7.1 Keberadaan lembaga dan organsiasi untuk melayani berbagai macam kepentingan pengguna hutan yang berbeda dan kelompok yang berkepentingan.

7.1.1.1 Badan Penasehat Desa (Tetua Adat).

7.1.3.1 Asosiasi dan kelompok pengembangan berbasis masyarakat.

7.1.3.2 Pengakuan atas keputusan yang dibuat oleh asosiasi/ kelompok pengembang.

Indonesia

\subsection{Organisasi sosial setempat memiliki kemampuan untuk} menegakkan hukum adat dan peraturan lainnya.

5.3.1 Pertemuan/rapat diadakan menyangkut masalah lingkungan dan penggunaan lahan.

5.3.2 Perempuan terwakili secara rata dalam pertemuan dan pengambilan keputusan.

5.3.2.1 Perempuan ikut hadir dalam pertemuan.

5.3.2.2 Perempuan ikut terlibat dalam diskusi.

5.3.3 Adanya pengambilan keputusan secara partisipatif.

5.3.3.1 Dalam rapat, keputusan dibuat oleh anggota masyarakat yang telah dewasa.

5.3.3.2 Partisipan memahami topik diskusi.

5.3.3.3 Dalam diskusi, tidak ada monopoli oleh pihak yang berkuasa.

5.3.3.4 Masyarakat menyetujui hasil keputusan rapat, baik di dalam maupun diluar pertemuan. 


\section{1.b Mekanisme pengelolaan lokal (norma, peraturan, undang- undang, dII)}

Agar dapat berpengaruh terhadap keputusan pengelolaan oleh masyarakat, sistem PHM yang mampu bertahan pada umumnya mengembangkan seperangkat instrumen pengelolaan yang sesuai untuk mengatur dan mengawasi penggunaan sumberdaya hutan oleh anggota masyarakat. Istilah mekanisme pengelolaan disini digunakan untuk mencakup seluruh instrumen formal dan informal, termasuk peraturan, norma, adat istiadat, larangan/tabu, undang-undang, dll yang telah dikembangkan masyarakat. Aturan-aturan tersebut terkadang rumit dan tidak jelas terlihat, dan layaknya organisasi itu sendiri, tertanam dalam kebudayaan setempat, spiritual dan lingkungan ekologinya. Mekanisme seperti diberlakukannya sangsi-sangsi bagi pelanggar aturan, merupakan hal yang sangat penting di Indonesia (melalui sistem adat tradisional). Di Indonesia dan Kamerun, kemampuan masyarakat untuk menyusun dan mengembangkan aturan-aturan yang merupakan adaptasi terhadap perubahan situasi dan kondisi dipandang sebagai hal yang sangat penting bagi kelangsungan lembaga masyarakat.

Brazil

\subsection{Masyarakat mengembangkan mekanisme untuk mengawasi dan memantau kegiatan yang produktif.}

5.6.1 Adanya mekanisme masyarakat untuk melakukan patroli dan pengawasan terhadap berbagai tahapan penebangan pohon kayu yang dilakukan baik oleh anggota masyarakat setempat atau orang luar.

5.6.2 Adanya mekanisme masyarakat untuk melakukan patroli dan pengawasan terhadap hasil hutan bukan kayu yang dilakukan oleh anggota masyarakat dan/atau orang luar.

5.6.3 Pengawasan dan Pemantauan terhadap penangkapan ikan yang dilakukan oleh anggota masyarakat dan/atau orang luar.

5.6.4 Masyarakat memiliki mekanisme pengawasan terhadap pengambilan dan penjualan hewan dan tanaman hias. 
6.2.1.c Peraturan masyarakat menyangkut penggunaan, kepemilikan dan hak kepemilikan atas sumberdaya agroforestry.

Kamerun

\subsection{Akses terhadap hutan masyarakat diatur melalui tindakan dan dukungan bersama.}

5.4.2 Pengembangan peraturan-peraturan baru dan praktek eksploitasi sebagai respon terhadap perubahan-perubahan yang terjadi secara nyata dalam sumberdaya secara keseluruhan.

\subsection{Keberadaaan sistem lokal untuk mengevaluasi dan memantau berbagai sumberdaya hutan.}

6.3.2 Anggota masyarakat ikut melakukan penilaian terhadap sumberdaya hutan.

\subsection{Lembaga masyarakat mempunyai kemampuan untuk menetapkan} dan membagi manfaat sumberdaya hutan.

7.2.1 Adanya nilai dan norma masyarakat dalam distribusi fungsi jenis satwa yang berukuran relatif besar.

7.2.2 Adanya jenis makanan yang ditabukan masyarakat.

Indonesia

5.1 Hukum adat dan peraturan-peraturan lainnya menjamin sistem kelestarian penggunaan lahan.

5.1.1 Sangsi dikenakan bagi mereka yang melanggar peraturan.

5.1.1.1 Sangsi khusus dikenakan terhadap sistem penggunaan lahan yang spesifik.

5.1.2.3 Diterapkannya sangsi pada kasus yang baru-baru ini terjadi.

5.1.2 Seluruh bagian masyarakat menghormati hukum adat dan peraturan lainnya menyangkut sistem lahan yang lestari.

5.1.4 Masyarakat menghormati peraturan-peraturan yang menjamin pemanfaatan hutan secara lestari.

5.1.5 Masyarakat menghormati peraturan-peraturan yang menjamin kelestarian fungsi hutan.

5.1.6 Masyarakat menghormati peraturan-peraturan yang menjamin kelestarian tembawang. 
5.1.7 Masyarakat menghormati peraturan-peraturan praktek perladangan berpindah yang menjamin periode/masa bera yang layak.

5.3.4 Peraturan-peraturan dan sangsi baru yang dapat menanggulangi masalah-masalah perkembangan yang baru menyangkut penggunaan lahan dan sumberdaya alam sedang dalam pengembangan.

\section{1.c Manajemen Konflik}

Di ketiga lokasi ditemukan bahwa masyarakat perlu menemukan cara untuk mengatasi konflik yang suatu saat dapat timbul. Cara tersebut dapat dilakukan secara formal atau informal. Masyarakat mengharapkan agar mekanisme tersebut dapat diterapkan secara efektif. Sebagai tambahan, kemampuan menggunakan mekanisme eksternal, yaitu legal atau kenegaraan untuk mengatasi konflik juga merupakan hal yang penting (lihat 4.b).

Brazil

\subsection{Keharusan adanya lembaga dan pengukuran yang efektif untuk mengatasi konflik.}

6.2.1 Terdapat mekanisme informal untuk merundingkan dan memecahkan masalah yang terjadi di masyarakat, perselisihan keluarga dan keluhan tentang kepemilikan dan pemanfaatan sumberdaya agroforestry.

6.2.1.b Dokumentasi perundingan dan penanganan konflik menyangkut sumberdaya agroforestry.

Kamerun

5.1.2 Keputusan penanganan konflik diambil oleh lembaga di dalam masyarakat.

5.1.2.2 Jumlah kasus yang dilaporkan menyangkut konflik tuntutan lahan yang diselesaikan dalam masyarakat dibandingkan dengan jumlah yang ditangani oleh hukum negara.

7.1.1 Masyarakat menghormati keputusan lembaga penyelesaian konflik. 
Indonesia

5.1.3 Adanya mekanisme penyelesaian konflik.

5.1.3.1 Anggota masyarakat yang dewasa dapat mengemukakan bagaimana cara menyelesaikan konflik penggunaan lahan.

5.1.3.2 Adanya kesepakatan tentang bagaimana konflik penggunaan lahan dapat diselesaikan.

5.1.3.3 Kasus-kasus yang baru terjadi menyangkut penanganan konflik tradisional penggunaan lahan.

\section{1.d Kewenangan untuk pengelola (status kepemilikan lahan)}

Masyarakat membutuhan jaminan kepemilikan atas sumberdayanya untuk memperoleh wewenang pengelolaan. Tanpa adanya jaminan status kepemilikan, orang sering ragu untuk melakukan investasi pengelolaan jangka panjang. Ketiga lokasi yang diuji memasukkan kriteria dan indikator yang mengacu pada sistem kepemilikan lahan masyarakat yang telah diakui masyarakat atau negara secara hukum (de jure). Isu status kepemillikan lahan termasuk juga permasalahan tata batas lahan milik umum atau hutan masyarakat, keberadaan peta yang menunjukan tata batas tersebut, dan atau adanya penerapan sistem hak dan adat yang sering kali rumit yang muncul pada masyarakat (lihat juga 2.d dan 4.b).

Brazil

\subsection{Terjaminnya hak untuk menempati, kepemilikan atas hak pakai penduduk dalam jangka waktu lama.}

6.1.1 Diakuinya kesepakatan antara pemilik lahan adat yang sah dan pemakai dalam pengelolaan agroforestry.

6.1.1.a Survei atas hak pemakaian lahan dan hak kepemilikan.

6.1.1.b Survei atas hak dan hukum adat untuk kemudahan penggunaan lahan dan hak kepemilikan.

6.1.1.c Adanya kesepakatan adat di dalam masyarakat menyangkut penggunaan sumberdaya lahan dan agroforestry. 
Kamerun

5.1 Akses masyarakat terhadap sumberdaya hutan dan lahan dalam jangka panjang secara jelas ditetapkan, diketahui dan dihormati.

5.1.1 Prosedur pemberian lahan diterima dan dihormati.

5.1.3 Kerangka kerja formal memuat kepemilikan lahan adat.

5.1.4 Batas-batas wilayah milik masyarakat diketahui dan dihargai oleh anggota masyarakat.

Indonesia

4.1 Sistem perlindungan kepemilikan lahan masyarakat dijamin oleh negara.

4.1.1 Sistem perlindungan kepemilikan lahan masyarakat dijamin oleh hukum negara dan peraturan.

4.1.2 Hak atas tanah milik masyarakat ditunjukkan dalam peta penggunaan lahan secara resmi.

4.1.3 Perubahan dan penyesuaian dari TGHK (Tata Guna Hutan Kesepakatan) ke dalam TGLDK (Tata Guna Lahan Desa Kesepakatan). 


\section{Prinsip 2. Kesejahteraan rakyat terjamin}

Diakui secara luas bahwa manusia yang memiliki mata pencaharian bersumber dari lahan hutan, dan tergantung kepada sumberdaya hutan, serta memperoleh kesejahteraan yang lebih tinggi dengan berinteraksi dengan hutan, memiliki kepentingan pribadi untuk mempertahankan kelangsungan hidup/kelestarian hutan tersebut. Prinsip ini menangkap pemikiran seperti ini. Cakupan $\mathrm{K} \& \mathrm{l}$ yang luas di ke tiga lokasi ini menandakan betapa bernilainya hutan bagi penduduk setempat. Kami lebih lanjut membagi contoh menjadi 4 (empat), berdasarkan dugaan ulang yang muncul bahwa manusia perlu untuk menjadi sehat, sejahtera dan bijaksana. Ke empat sub-bagian tersebut adalah:

\section{a. Kesehatan dan makanan \\ b. Kesejahteraan (mata pencaharian, pembagian biaya dan keuntungan, kesetaraan)
c. Kebijaksanaan dan kebersamaan dalam berbagi ilmu pengetahuan

d. Kesepakatan kepemilikan lahan di dalam masyarakat

\section{2.a Kesehatan dan makanan}

Di Brazil dan Kamerun, K\&l dikembangkan untuk menunjukkan bahwa interaksi dengan hutan memberikan manfaat secara langsung terhadap kesehatan dan kesejahteraan fisik manusia. Banyak hal yang menunjukkan pentingnya hasil hutan sebagai sumber bahan makanan. Di Indonesia, tidak ada acuan yang dibuat menyangkut makanan atau kesehatan masyarakat. Hal ini tidak biasa. Kebanyakan K\&l pengelolaan hutan lestari dan kesehatan masyarakat setempat dijadikan sebagai kriteria penting. Di Brazil, dimasukkan pula pemikiran tambahan bahwa pengawasan petumbuhan populasi dan reproduksi sangat penting untuk kelestarian pengelolaan hutan. 
Brazil

6.7 Kegiatan pengelolaan yang diterapkan pada sumberdaya agroforestry memberikan sumbangan secara nyata terhafap kesejahteraan penduduk setempat secara biologis, sosial ekonomi dan budaya.

6.7.5.b Konsumsi makanan oleh unit domestik dengan perhatian khusus pada produk agroforestry.

6.7.5.f Pertumbuhan populasi yang lambat dan stabil.

6.7.5.g Keluarga berencana dan pemakaian alat kontrasepsi.

6.7.8.c Pengolahan produk agroforestry tampak dalam penggunaan dapur tradisional.

3.1.1 Kepentingan sosial ekonomi atas protein hewani yang berasal dari sumberdaya akuatik bagi penduduk setempat tetap nyata.

2.1.3 Daging hasil buruan tetap penting bagi sumber makanan penduduk setempat.

Kamerun

\subsection{Kesejahteraan rakyat terjamin.}

1.6.1 Kesehatan terjamin melalui tumbuhan obat yang dikumpulkan dari hutan.

1.6.1.1 Bukti dari adanya kulit, benih, buah-buahan, daundaunan yang diambil dan digunakan untuk konsumsi setempat.

1.6.2 Sebagian besar produk yang dikonsumsi oleh rakyat diambil dari ekosistem hutan.

1.6.2.1 Kebiasaan makan tergantung pada ekosistem hutan setempat.

1.6.2.2 Bukti beraneka ragam penggunaan resep makanan.

3.2 Peran hutan alam dalam pembinaan kesehatan masyarakat dipelihara dengan penuh kesadaran.

3.2.1 Terdapat beragaram produk hutan yang memiliki nilai gizi tinggi sebagai bahan tambahan makanan dan lauk pauk.

3.2.1.2 Hutan memberikan kontribusi bagi makanan penduduk setempat. 
3.2.2 Tersedianya buku ringkasan berisi informasi tanaman obatobatan, semak, jamu, ular, katak, dll, yang digunakan oleh penduduk setempat untuk mengobati penyakit dan kelainan fisik.

3.2.3 Daerah aliran sungai dan jalan air (kanal/terusan) dilindungi untuk kepentingan kesehatan masyarakat.

3.2.4 Penggunaan api untuk pembukaan lahan diminimalisasi untuk mencegah penyakit pernafasan.

\section{2.b Kesejahteraan (mata pencaharian, pembagian biaya dan manfaat, kesetaraan)}

Di ketiga lokasi terdapat banyak contoh kriteria dan indikator yang menunjukkan mata pencaharian penduduk setempat bergantung pada keberadaan hutan. Permasalahan yang dibahas disini mencakup keuntungan ekonomi yang diperoleh dari hutan baik secara langsung atau melalui industri kecil (kerajinan tangan), sehingga memberikan nilai tambah bagi bahan mentah hutan melalui ketrampilan dan kreatifitas pekerjanya. Kamerun dan Brazil menyoroti masalah hasil hutan ganda dan beraneka ragam, dan pentingnya kelompok pengguna hutan yang berbeda yang saling melengkapi dengan cara menggunakan sumberdaya yang berbeda. Indonesia menekankan pemerataan pembagian produk hutan (lihat juga 4.c).

Brazil

5.7 Keuntungan yang diperoleh dari kegiatan yang produktif digunakan sebagai insentif untuk tetap melangsungkan kegiatan tersebut secara lestari.

5.7.1 Upaya terus menerus untuk mendiversifikasi dan meningkatkan nilai tambah kapasitas proses dengan tujuan meningkatkan nilai agregat kotor produk.

6.7.1 Kegiatan pengelolaan yang diterapkan pada sumberdaya agroforestry menghasilkan subsidi bagi pemeliharaan/bisnis skala kecil dan industri rumah tangga. 
6.7.2 Tingkat ketergantungan terhadap bahan mentah yang dihasilkan dan diperoleh di dalam masyarakat.

6.7.4 Kegiatan pengelolaan sumberdaya agroforestry memberikan kontribusi ekonomi bagi akses masyarakat terhadap pendidikan, kesehatan dan pelayanan sosial lainnya.

6.7.5 Adanya keuntungan yang diperoleh sebagai mata pencaharian tetap dan reproduksi unit domestik yang berasal dari pengelolaan sumberdaya agroforestry.

6.7.5.a Penghitungan unit domestik produksi agroforestry.

6.7.5.c Inventarisasi aset rumah tangga domestik dan peralatan.

6.7.5.d Fluktuasi pendapatan unit domestik dari kegiatan pengelolaan sumberdaya agroforestry.

Kamerun

5.2 Hasil hutan memberikan kontribusi yang nyata menyangkut kesejahteraan sosial ekonomi di berbagai tingkat usia dan perbedaan jenis kelamin di dalam masyarakat.

5.2.1 Pentingnya hasil hutan untuk menunjang pendapatan rumahtangga baik tunai maupun non-tunai.

3.3 Berbagai pengguna hutan dan kelompok yang berkepentingan terhadap hasil hutan hidup berdampingan dengan harmonis.

3.3.1 Berbagai macam lapisan masyarakat pengguna hutan memiliki kepentingan yang saling melengkapi dan tidak melakukan persaingan yang merugikan.

3.3.2 Keuntungan dari hasil hutan memberikan tambahan di berbagai sektor pada masyarakat pedesaan.

3.3.2.1 Keberadaan industri rakyat yang menggunakan keahlian penduduk asli dan mendorong panen dan penggunaan bahan mentah hutan secara bijaksana.

3.3.2.2 Industri kecil setempat membuka kesempatan kerja bagi penduduk. 
3.3.2.3 Keberadaan produk bernilai tambah yang dihasilkan di wilayah setempat untuk penggunaan lokal dan dijual.

3.3.2.5 Seleksi jenis dan tanaman serta penerapan standar kualitas pengrajin menghasilkan nilai tambah produk dan berdaya guna lama (misalnya lumpang, sampan, dII.)

Indonesia

5.3 Hukum adat dan peraturan lainnya menjamin akses untuk mengambil sumberdaya alam secara adil dan juga pembagian produk/hasil secara merata diantara anggota masyarakat.

5.2.1 Peraturan menjamin akses hutan yang adil bagi seluruh stakeholder.

5.2.2 Peraturan menjamin distribusi produk tembawang kepada seluruh stakeholder.

5.2.3 Peraturan menjamin distribusi air irigasi secara adil apabila terdapat sawah.

3.4 Tembawang mampu memberikan nafkah bagi penghidupan rakyat.

3.4.1 Tembawang menghasilkan buah-buahan komersial dan kebutuhan hidup lainnya.

\section{2.c Kebijaksanaan dan saling berbagi ilmu pengetahuan}

Aspek utama dalam pengelolaan hutan lestari adalah dasar pengetahuan masyarakat yang berlaku/hidup dan berjalan baik, dan pengelolaan dilakukan atas dasar kebijakan bersama masyarakat. Alih pengetahuan antara generasi (dari tua ke muda) merupakan hal penting demi menjaga kelangsungan pengetahuan tersebut untuk masa depan, dan yang demikian ini ditekankan di ketiga lokasi uji. Seperti contohnya, di Indonesia, alih pengetahuan melalui pendidikan ditunjukkan dalam bentuk Prinsip. Brazil dan Indonesia juga mengacu pada unsur moral sebagai pengetahuan yang dihasilkan olek penduduk lokal (hati nurani 
penduduk setempat, etika lingkungan) yang merupakan dasar dalam menjalankan kehidupan. Hal ini tampak penting bagi kehidupan spiritual dan kebudayaan masyarakat lokal agar berakar kuat di dalam ekosistem hutan.

Dari sekumpulan perangkat di bawah ini, terlihat pentingnya pengetahuan yang dihasilkan oleh penduduk setempat bagi pengelolaan hutan lestari tidak dapat diabaikan. Bukan saja disebabkan kemunculannya yang berkali-kali namun, sebagaimana dalam kasus contoh di Kamerun, berada pada hirarki K\&l paling tinggi (misalnya, penggunaan pengetahuan penduduk asli merupakan Prinsip dari kelestarian). Meskipun secara khusus kami telah memasukkan pengetahuan ke dalam Prinsip kesejahteraan rakyat, ini merupakan isu yang menonjol, dan nampaknya 'pengetahuan tentang' akan menjadi istilah umum disepanjang rangkaian K\&l (lihat juga 4.d).

Brazil

\subsection{Hati nurani penduduk lokal dan pengetahuan tentang penggunaan dan pengelolaan sumberdaya agroforestry menunjukkan etika tata guna lahan yang lestari dan upaya konservasi.}

6.8.1 Sejumlah besar pengetahuan lokal tentang penggunaan sumberdaya agroforestry, terutama hasil hutan bukan kayu.

6.8.2 Pemanfaatan hasil hutan bukan kayu pada teknologi setempat dan infrastruktur.

6.8.2.a Penggolongan yang dibuat oleh penduduk setempat menyangkut hasil produk agroforestry yang digunakan untuk pabrik dan produksi artefak.

6.8.3 Bukti adanya kode simbol dan mitos yang mempunyai pengaruh mengatur serta memberikan kontribusinya dalam upaya mengkonservasi sumberdaya agroforestry.

6.7.7 Penyebaran dan upaya mempertahankan (lisan dan tertulis) pengetahuan tradisional dan mitos.

6.7.8 Identitas budaya erat hubungannya dengan lanskap agroforestry, manfaatnya yang beranekaragam dan hubungannya dengan ritualisasi. 
Kamerun

\subsection{Struktur sosial membuka jalan bagi penyebaran sistem pengetahuan yang ada.}

6.1.1 Cerita rakyat dan kitab suci menyoroti hubungan hutanmasyarakat.

6.1.2 Kelompok pengguna yang berbeda mengadakan perjalanan eksploitasi hutan bersama.

6.1.3 Ekspedisi eksploitasi hutan memasukkan distribusi pengetahuan.

\subsection{Pengetahuan tentang hutan digunakan sebagai mekanisme untuk} menjamin mata pencaharian minimal bagi anggota masyarakat.

6.2.1 Frekuensi kunjungan ke hutan menandakan adanya ketergantungan.

Indonesia

3.1.3 Adanya konsep tradisional untuk konservasi.

7.1.3 Pendidikan non-formal masih berfungsi.

7.1.3.1 Menceritakan dongeng masih dilakukan oleh orang tua kepada anak-anaknya.

7.1.3.2 Sejarah daerah setempat masih terus diceritakan/ diwariskan kepada generasi muda.

7.1.3.3 Pengetahuan lokal menyangkut pengelolaan sumberdaya alam masih tetap diwariskan kepada generasi muda.

\section{2.d Kesepakatan status kepemilikan lahan dalam masyarakat}

Di kebanyakan PHM yang tetap berlaku, perlunya kepastian akses yang merata terhadap hutan dan sumberdaya lainnya menimbulkan perkembangan adanya kesepakatan status kepemilikan lahan setempat. Kesepakatan penting ini berlaku antar perorangan (dan/atau rumah tangga atau kelompok) dan masyarakat; kesepakatan (sedikitnya yang awal) ini sesuai dengan budaya lokal dan kebutuhan pengelolaan sumberdaya, dan biasanya didukung oleh norma dan peraturan yang berlaku. 
Hubungan antar individual (rumah tangga/kelompok), masyarakat dan wilayah sumberdaya, ditentukan dalam kerangka spasial dan sementara, seperti misalnya, 'siapa yang dapat melakukan apa dan dimana'. Hubungan status kepemilikan lahan yang ditetapkan dengan baik dan dapat diterima sangat penting bagi insentif untuk mendorong, melindungi dan menjamin komitmen antar generasi. Meratanya hak penggunaan sangat penting bagi kesejahteraan rakyat, sebagaimana ditekankan di Brazil. Hak peninggalan/warisan dan diteruskannya hak tersebut untuk generasi berikutnya merupakan aspek kunci kelestarian. Bagian ini yang menyangkut kepemilikan secara individual berhubungan erat dengan bagian lainnya, termasuk status kepemilikan dan kewenangan pengelolaan di tingkat masyarakat (lihat 1.d), dan distribusi isu dalam bagian yang menyangkut kesejahteraan (lihat 2.b). Di Brazil dan Kamerun, kepemilikan sumberdaya secara individu merupakan Kriteria, tetapi di Indonesia isu kepemilikan secara individu diperlakukan sebagai crosscutting sehingga nampak sebagai Penguji di beberapa wilayah.

Brazil

\subsection{Akses dan pemanfaatan Iahan umum dan sumberdaya agroforestry dilindungi untuk kepentingan semua anggota masyarakat tanpa memandang jenis kelamin, warna kulit, agama atau kelas sosial.}

6.3.1 Ada norma/hukum untuk pengaturan akses sumberdaya agroforestry.

6.2.1.c Identifikasi terhadap aturan masyarakat secara internal menyangkut pemanfaatan, dan hak kepemilikan sumberdaya agroforestry.

Kamerun

\subsection{Bukti terhadap hak pemanfaatan/akses ditunjukkan oleh anggota masyarakat.}

5.1.1 Prosedur pemberian lahan diterima dan/atau dihormati.

5.1.1.1 Sejarah tentang penggunaan lahan dan/atau kependudukan.

5.1.1.2 Pola pewarisan lahan milik. 
Indonesia

5.2.2.2 Terjaminnya hak milik perorangan dan masyarakat atas tembawang.

5.2.2.3 Aturan yang jelas menyangkut hak waris.

5.2.2.4 Aturan yang jelas menyangkut hak untuk memanen produk tembawang.

5.2.2.5 Aturan menyangkut kepemilikan lahan hasil hutan bukan kayu (HHBK). 


\section{Prinsip 3. Kesehatan hutan terjamin}

Prinsip ini memberikan gambaran bahwa seluruh lanskap ada dalam kondisi yang baik sebagai hasil dari sistem pengelolaan yang ditetapkan. Prinsip yang sangat luas ini ditujukan agar secara umum cukup untuk memperoleh berbagai cara pandang/pola pikir masyarakat yang berbeda terhadap sumberdaya yang mereka miliki. Hal tersebut meliputi: kondisi daratan dan perairan, kesehatan ekologi hutan, kondisi dan pengelolaan bagian lanskap yang digunakan secara permanen atau sementara untuk budidaya, dan meliputi "praktek terbaik" dengan berbagai ragam kemungkinan intervensi manusia terhadap hutan termasuk hasil HHBK (tumbuhan dan satwa), ekstraksi/pemanenan kayu, rotasi perladangan berpindah, agroforestry dan silvikultur.

Pada kebanyakan perangkat K\&l konvensional, pokok-pokok bahasan yang didiskusikan disini umumnya dibagi ke dalam paling tidak 2 (dua) kelompok, yaitu ekologi dan pengelolan hutan. Namun demikian, di ke tiga lokasi uji pembagian tersebut tidak dapat diterapkan. Apakah berburu merupakan isu keanekaragaman hayati atau bagian dari pengelolaan hutan? Pada kebanyakan konteks pengelolaan asli (indigenous) dan masyarakat, tidak ada perbedaan antara hutan yang 'dikelola' dan ekosistem 'alami'. Masyarakat mengelola ekologi lanskap secara keseluruhan. Prinsip yang luas ini bertujuan untuk mencakup integritas lanskap hutan dengan cara yang lebih holistik. Tidak akan ada dua masyarakat yang membagi pengelolaan lanskap hutannya kedalam Kriteria yang sama, dan ada perbedaan yang signifikan (nyata) pada struktur K\&l diantara 3 (tiga) lokasi uji. Kami menyajikan contoh K\&l untuk Prinsip ini, dengan bagian-bagian sebagai berikut:
a. Perencanaan (zonasi dan kawasan dilindungi)
b. Pengelolaan fungsi ekosistem (daratan, air dan api)
c. Intervensi produktif 1 (pertanian dan agroforestry)
d. Intervensi produktif 2 (HHBK berupa tumbuhan)
e. Intervensi produktif 3 (HHBK berupa satwa)
f. Intervensi produktif 4 (kayu) 


\section{g. Kesehatan hutan 1 (keanekaragaman hayati) \\ h. Kesehatan hutan 2 (struktur dan regenerasi) \\ i. Keanekaragaman lanskap (fragmentasi dan mozaik)}

\section{3.a Perencanaan (zonasi dan kawasan perlindungan)}

Bagian ini meliputi K\&l yang mengakui bahwa lanskap hutan tidaklah homogen, dan pengelolaannya membutuhkan kepekaan terhadap adanya perbedaan tipe lahan dan wilayah. Termasuk di dalamnya adalah kawasan dilindungi dan tempat-tempat sakral. Bagian ini juga berkaitan dengan keanekaragaman lanskap (lihat 3.i) dan dengan isu batas dan status kepemilikan lahan (lihat 1.d dan 2.d).

Brazil

\subsection{Pemeliharaan jangka panjang areal cadangan dan individu reproduktif menjadi pertimbangan masyarakat dalam rangka menjamin kelangsungan hidup populasi.}
4.1.1 Terpeliharanya hutan cadangan dan cagar alam dengan ukuran yang memadai dan tersebar diantara daerah hutan yang dikelola oleh masyarakat.

5.1.2 Keberadaan zona-zona (areal yang telah ditetapkan untuk intensitas penggunaan yang berbeda sesuai dengan potensi sumberdaya).

2.1.5 Keberadaan kawasan yang jarang diburu atau tidak diburu di dalam kawasan milik masyarakat yang mudah diakses oleh pemburu.

5.2.1 Keberadaan rencana pengelolaan dan rencana tahunan untuk kayu.

5.3.1 Keberadaan rencana pengelolaan dan rencana tahunan untuk HHBK.

6.7.6 Daerah yang dihormati dan dilindungi karena nilai budayanya yang tinggi diprioritaskan dalam alokasi seluruh bentuk pemanfaatan dan eksploitasi sumberdaya alam. 
Kamerun

5.3 Lokasi-lokasi yang mempunyai nilai sosial budaya yang khusus, sejarah dan turisme bagi masyarakat setempat dikenal dan dilindungi oleh mekanisme kontrol sosial.

5.3.1 Adanya lokasi-lokasi yang mempunyai nilai mistik sosial budaya yang nyata bagi masyarakat.

3.1 Penduduk pedesaan mempunyai pengetahuan yang cukup tentang komposisi dan distribusi tipe hutan yang berbeda.

3.1.1 Batas hutan dengan seluruh desa di sekitarnya dikenali dan dihormati oleh semua pihak terkait.

3.1.1.2 Berbagai tipe hutan seperti jenis indikator di hutan payau dan hutan sekunder, kawasan hutan yang kaya jenisnya, jenis kayu bernilai, semak, herba, sungai, jenis ikan dan lokasinya di dalam hutan diketahui secara tepat dan akurat.

Indonesia

2.2 Pengelolaan setiap sistem penggunaan lahan mempertimbangkan karakteristik dan batas kawasan cagar alam dan kawasan dengan intensitas penggunaan yang berbeda.

2.2.1 Kawasan cagar alam dimiliki bersama dan intensitas penggunaannya rendah.

2.2.2 Lahan pertanian permanen dimiliki secara perorangan dan intensitas penggunaannya tinggi.

1.1.1 Kawasan dengan nilai ekologi tinggi diketahui dan dilindungi.

\section{3.b Pengelolaan fungsi ekosistem (daratan, air dan api)}

Bagian ini menunjukkan bahwa mengelola lanskap hutan melibatkan lebih banyak hal dibandingkan dengan mengelola pohon. Melihat kenyataan bahwa orang yang hidup di hutan bergantung pada sungai, menggunakan anak sungai untuk transportasi, makan, irigasi dan kesehatan, maka pengelolaan sumberdaya air merupakan isu di tiga 
lokasi uji. Pengelolaan api juga penting di semua lokasi. Masalah pengelolaan tanah sangat nyata pada perangkat yang digunakan di Kamerun dan Indonesia. Ketiga isu tersebut saling berkaitan. Pengelolaan air mempengaruhi tanah melalui erosi, dan pengelolaan api mempengaruhi tanah melalui kontribusi abu untuk kesuburan. Pengelolaan sumberdaya inti ini secara aktif meningkatkan kelestarian. Pendekatan untuk menilai pengelolaan di tiga lokasi uji ini sangat berbeda: Brazil memilih untuk menganalisa kondisi sumberdaya (lihat Penguji untuk kualitas air), dan dua lokasi uji yang lain menitik beratkan pada penilaian praktek pengelolaan (lihat Penguji untuk pengelolaan api di Indonesia).

Brazil

1.4 Minimasi resiko kebakaran pada kawasan bera dan hutan primer melalui penerapan teknik pengelolaan kebakaran secara tepat.

1.4.1 Tidak terjadi kebakaran liar.

5.5.4 Masyarakat memiliki peraturan dan undang-undang untuk mengawasi penggunaan api pada penyiapan lahan areal pertanian, pembersihan areal peternakan dan kegiatan lainnya.

\subsection{Pemeliharaan integritas ekologi seluruh ekosistem perairan (sungai, mata air, danau, dan lain-lain).}

1.5.1 Pemeliharaan daerah rawan banjir, produktivitas aliran sungai dan proses alami yang melestarikan atau membantu satwa dan tumbuh-tumbuhan perairan (integritas fisik).

1.5.2 Tidak ada proses kontaminasi perairan (kualitas air memenuhi persyaratan dari parameter kimia dan biologi).

1.5.2.1 Kejernihan, bau, dan rasa dari air.

1.5.2.2 Terjadinya peningkatan alga dan kematian ikan secara abnormal.

1.5.2.3 Terjadinya kontaminasi E. coli yang berasal dari kotoran manusia dan hewan (faeces). 
Kamerun

\subsection{Sumbedaya air dikelola secara tepat.}

1.7.1 Dihormatinya keberadaan masa/musim memancing.

1.7.2 Akses ke mata air untuk memancing diatur dan diawasi.

1.7.3 Metode dan peralatan memancing yang menjamin regenerasi ikan.

1.7.4 Tambak pemijahan ikan diciptakan untuk mengurangi tekanan eksploitasi terhadap populasi ikan.

1.4.2 Praktek pertanian mempunyai dampak jangka pendek yang menguntungkan bagi lahan garapan, tanah dan pohon.

1.4.2.1 Pengawetan terhadap pohon yang dipupuk selama pembukaan lahan.

1.4.2.2 Pemeliharaan terhadap penutup tanah setelah pembukaan.

1.4.2.3 Merangsang biji pohon dorman dengan menggunakan api.

4.2.1.2 Perhatian ditujukan pada faktor iklim dan musim pada saat penggunaan api untuk pertanian.

1.4.2.6 Bahan mineral yang diperoleh berasal dari abu.

1.4.4.5 Pembuatan dan penggunaan kompos.

1.4.3 Masa bera yang cukup panjang agar kesuburan tanah dapat pulih kembali.

Indonesia

\subsection{Terpeliharanya fungsi ekosistem yang kritis.}

1.1.2 Sumberdaya air dilindungi.

1.1.3 Kualitas air dan tanah dipelihara demi kemantapan kelestarian ekosistem.

1.1.4 Minimasi erosi tanah.

\subsection{Setiap sistem penggunaan lahan ditempatkan pada kondisi tanah} yang sesuai.

2.1.1 Adanya pengetahuan lokal yang memadai tentang tipe-tipe tanah dan kesuburan/vegetasi yang belum ditanami (fallow vegetation) 
3.7.3 Diterapkannya sistem pengelolaan api dalam pembukaan ladang.

3.7.3.1 Bukti disiapkannya mekanisme pemadaman api sebelum membakar.

3.7.3.2 Pembakaran mempertimbangkan arah angin dan kecepatannya.

3.7.3.3 Bukti adanya pembakaran dari bagian terendah ke bagian tertinggi.

3.7.3.5 Tidak ditemukannya tumbuhan rusak yang disebabkan oleh api tidak terkontrol.

\section{3.c Intervensi produktif 1 (pertanian dan agroforestry)}

Adanya kepercayaan yang kuat diantara anggota masyarakat bahwa pertimbangan pengelolaan hutan secara lestari harus memperhitungkan kawasan agroforestry dan budidaya di dalam lanskap (lihat Kotak 3). Pengelolaan yang baik pada kawasan ini disertai langkah intensifikasi dan optimasi dianggap sebagai cara penting untuk mengurangi dampak terhadap sumberdaya hutan. Di tiga areal uji, sejumlah besar praktek yang baik untuk kelestarian telah diidentifikasi, termasuk metode ramah lingkungan/ berdampak rendah (low-impact methods), metode untuk meningkatkan hasil tanpa memperluas areal budidaya, optimasi (optimisation), mengembangkan pertanian menetap di daerah yang cocok, menggunakan waktu yang tepat untuk praktek musiman, dan pembuahan ternak.

Brazil

\subsection{Praktek pertanian dilakukan sesuai aturan dengan tujuan untuk meminimasi dampaknya terhadap hutan.}

5.5.5 Penerapan perlakuan berdampak rendah dan metode peternakan (dalam pengawasan hama dan penyakit, penjarangan, dan lain-lain). 
Kotak 3. Contoh intervensi produktif di tiga lokasi uji CIFOR.

\section{Desa Sao Pedro dan Cachoeira de Maro, Para Brazil}

Penduduk desa ini mempraktekkan pertanian berpindah. Singkong merupakan tanaman pokok yang paling penting dan diproses menjadi tepung, dan sedikit kelebihannya dijual ke pasar. Banyak keluarga mempunyai perkebunan karet dengan luasan kecil. Termasuk dalam Hutan Rakyat (communities forest) adalah beberapa hutan kacang Brasil dengan luasan kecil yang tersebar luas. Desa ini juga relatif kaya akan hasil beberapa jenis HHBK. Perusahaan-perusahaan kecil pembuat kapal menggunakan kayu, serat dan resin dari hutan. Perusahaan tersebut merupakan milik pribadi (private concerns) yang terdiri dari ahli pembuat kapal lokal yang melatih orang magang. Penebangan pohon dan dijadikan papan masih dilakukan dengan menggunakan kapak. Berburu dan memancing merupakan aktivitas penting, dengan beberapa anggota masyarakat yang mempunyai keahlian disalah satu bidang tersebut.

\section{Bedigong dan Darok, Kabupaten Sanggau, Kalimantan Barat, Indonesia}

Penduduk pedesaan ini juga merupakan peladang berpindah. Tanaman ekonomis utama adalah karet yang tumbuh dalam tegakan kecil. Desa ini merupakan salah satu desa yang terkenal dengan Kebun Hutan Tembawang. Kebun ini ditanam pada petak pertanian yang akan ditinggalkan. Umumnya kawasan ini lebih kaya akan jenis-jenis tanaman hutan yang berguna dibandingkan dengan hutan alam. Jenis dominan adalah tengkawang (Shorea macrophylla), pohon hutan yang tinggi, yang menghasilkan kacang penghasil minyak bernilai komersial tinggi, yang mempunyai nilai ekonomis lokal kedua tertinggi setelah karet . Hasil hutan lain yang penting adalah madu, rotan, papan/sirap dan kayu besi. Di desa yang lebih besar yaitu Darok, beberapa kebun Tembawang telah dikonversi menjadi sawah irigasi.

\section{Desa Eyek II dan Akak/Bitetele, Propinsi Tengah, Kamerun}

Desa Bantu Bulu terletak di wilayah yang sebelumnya adalah hutan bekas tebangan yang kaya. Masyarakat berhasil menentang perusahaan pembalakan untuk masuk wilayah mereka. Penduduk datang pada tahun 1920-an, ketika nenek moyang penduduk yang ada saat ini berhasil mencapai wilayah tersebut setelah dasawarsa migrasi perlahan melewati negara ini. Lemahnya prasarana menyebabkan mereka menjadi sedikit terisolasi dari ekonomi pasar dan memaksa mereka tergantung pada hutan untuk mata pencahariannya. Sebagai peladang berpindah, beberapa keluarga juga mempunyai petak sempit dengan tanaman kopi dan coklat. Sejak pertengahan tahun 1980-an, hasil bumi ini terancam diabaikan karena jatuhnya harga, konsekuensi dari hal tersebut adalah menurunnya laju konversi hutan dan areal bera. Penduduk umumnya berburu dan memancing serta mengumpulkan HHBK dari hutan, seperti makanan, daun-daun pembungkus, obat-obatan, serat, bahan bangunan dan bahan-bahan untuk pabrik kerajinan lokal. HHBK dari jenis lokal penting termasuk rotan dan rafia, daun-daun pembungkus dan beberapa buah-buahan dan rempah-rempah, termasuk mangga semak (Irvingia gabonensis), buah moabi (Baillonella toxisperma) dan biji-biji dari Ricinodendron heudelotii. Dibawah kepemimpinan seorang kepala desa, tokoh-tokoh dan para pemimpin, desa ini telah mengembangkan suatu aturan/hukum dan peraturan-peraturan untuk mengatur aliran keuntungan yang diperoleh dari hutan. 
Kamerun

1.4 Dampak negatif pertanian pada ekosistem hutan diminimasi.

1.4.1 Kegiatan pertanian dilokalisasi.

1.4.4 Pengukuran dilakukan untuk meningkatkan hasil pertanian.

2.1.1.4 Tanaman campuran dan tahapan penanaman membantu menjamin ketersediaan pangan sepanjang tahun dan sebagai persediaan jika terjadi kegagalan tanaman.

4.2.1 Lahan pertanian dibersihkan (tebas dan bakar) sebelum musim hujan, sehingga tanaman ditanam pada waktu yang tepat.

4.2.1.1 Tidak ada tanda menyangkut ketidaktepatan waktu atau keterlambatan dalam penyiapan lahan seperti menyia-nyiakan lahan yang sudah disiapkan dan kehilangan hasil.

Indonesia

\subsection{Diterapkannya pertanian lestari dengan input rendah.}

3.7.1 Kebun karet diintensifkan.

3.7.2 Adanya distribusi kelas umur.

\subsection{Optimisasi dari sistem agroforestry lokal.}

6.2.1 Optimisasi Tembawang (kebun hutan).

6.2.3 Produktifitas dan kualitas kebun karet harus ditingkatkan.

6.2.3.1 Bukti adanya teknologi yang memadai untuk perbaikan pohon (tree improvement).

6.2.3.2 Bukti adanya teknologi yang memadai untuk periode setelah (pasca) panen dan pemrosesan.

6.2.4 Adanya kebijakan dan kegiatan untuk merasionalisasikan sistem ladang.

\subsection{Pertanian menetap dikembangkan pada saat kondisi sosial ekonomi mengizinkan.}

6.3.1 Persetujuan diantara stakeholder tentang konversi bagian dari lingkungan menjadi pertanian irigasi.

6.3.3 Adanya peternakan satwa yang memadai. 


\section{3.d Intervensi produktif 2 (HHBK berupa tumbuhan)}

Hasil hutan bukan kayu (HHBK) memegang peranan penting untuk masyarakat yang tergantung pada hutan dan merupakan kekayaan yang penting bagi ilmu pengetahuan. Hal tersebut terutama berkaitan dengan praktek pengelolaan dan pemanenan yang baik. Meskipun demikian, secara jelas akan tidak praktis mengembangkan K\&l untuk setiap intervensi tertentu. Di tiga lokasi uji, beberapa Kriteria umum bagi ekstrasi secara lestari HHBK penting tertentu dikembangkan dengan beberapa indikator spesifik. Indikator untuk HHBK tampaknya cukup spesifik untuk hasil hutan di areal setempat. Semua isu HHBK juga saling berkaitan dengan K\&l keanekaragaman hayati (lihat 3.g).

Brazil

5.3 Eksploitasi hasil hutan bukan kayu dilakukan berdasarkan praktek yang lestari.

5.3.2 Diterapkannya teknik berdampak rendah.

5.3.3 Diterapkannya perlakuan silvikultur.

5.3.4 Praktek pemanenan untuk setiap jenis sesuai dengan potensi produktif spesies tersebut.

4.2 Praktek ekstraksi minyak atau getah batang pohon, tidak memiliki pengaruh yang merugikan terhadap viabilitas demografik jenisjenis yang dipanen.

4.2.1 Pohon Copaifera yang sebelumnya merupakan komiditi untuk diteres minyaknya, tidak mengalami laju kematian yang lebih tinggi dari pada pohon-pohon yang tidak diteres pada populasi yang sama.

\subsection{Ekstraksi lateks dan resin yang diperoleh dari pohon dikerjakan} berdasarkan prinsip kelestarian.

4.4.1 Populasi lokal dari pohon penghasil lateks (seperti Hevea, Brosimum, Couma dan Manilkara spp.) secara demografi dapat bertahan hidup (Demographically viable). 
Kamerun

\subsection{HHBK harus dikelola secara lestari.}

1.5.1 HHBK dikenali.

1.5.1.2 Pengetahuan tentang kapasitas regenerasi untuk setiap jenis.

1.5.2 Teknik pemanenan HHBK dijamin lestari.

1.5.2.1 Keberadaan tehnik konservasi.

1.5.2.2 Tidak adanya tehnik yang merusak (destruktif).

1.5.2.3 Upaya untuk mendomestikasi jenis-jenis tertentu.

\subsection{Teknik-teknik pemanenan yang lestari.}

3.1.1 Pemanenan daun, penghisap (sucker), akar, batang, cabang, dan lain-lain yang bersifat merusak dihindari untuk menjamin keberadaannya pada waktu diperlukan.

\subsection{Diketahuinya pola musiman dalam pemanfaatan sumberdaya} hutan dan kegiatan pertanian.

3.2.2 Bagian-bagian tumbuhan termasuk kulit kayu dikumpulkan pada musimnya.

Indonesia

\subsection{Pemanenan berdampak rendah/ramah lingkungan telah diterapkan.}

3.2.1 Pemanenan yang menyebabkan kerusakan minimum.

3.2.2 Peralatan yang digunakan disesuaikan dengan pengetahuan tehnologi setempat.

3.2.3 Gangguan minimum terhadap habitat satwa.

3.2.4 Hanya hasil hutan bukan kayu yang telah dewasa saja yang dipanen.

6.1.2 Ekstraksi HHBK secara lestari dibawah pengelolaan masyarakat. 


\section{3.e Intervensi produktif 3 (HHBK berupa satwa)}

Berburu dan memancing merupakan hal penting bagi beberapa masyarakat yang tergantung pada hutan; produk hewan lainnya, seperti madu, juga memberikan gambaran yang kuat. Perhatikan bahwa topik memancing berkaitan dengan pengelolaan air (lihat 3.b) dan seluruh isu HHBK berkaitan dengan keanekaragaman hayati (lihat 3.g).

Brazil

4.5 Ekstraksi produk satwa yang digunakan di dalam perekonomian setempat tidak berdampak negatif terhadap dinamika populasi satwa yang berasosiasi dengan produk tersebut.

4.5.1 Metode ekstraksi madu tidak merusak sarang lebah atau pohon kayu berlubang yang berasosiasi dengan lebah.

5.4 Aktivitas memancing dilakukan berdasarkan prinsip kelestarian.

5.4.1 Keberadaan peraturan dan norma untuk melaksanakan kegiatan pemancingan berdampak rendah.

3.1 Eksploitasi sumberdaya perairan tidak menyebabkan kepunahan ikan dan populasi kura-kura secara ekonomis maupun demografis.

3.1.2 Penampungan ikan alami atau tempat pemijahannya dipelihara, dan berfungsi sebagai suplai atau sumber ikan bagi di bagian-bagian sungai atau sungai kecil tempat dimana terjadi eksploitasi ikan secara berlebihan.

3.1.3 Ikan yang ditangkap secara sengaja atau secara kebetulan, memiliki ukuran di atas ukuran kritis kematangan reproduktif setiap jenis.

3.1.5 Pengambilan telur kura-kura (Podocnemis spp.), betina muda dan tua yang ada di pantai secara total dilarang.

2.1.6 Perburuan secara komersial tidak diperkenankan di dalam masyarakat. 
Kamerun

1.3 Strategi asli (indigenous) yang bertujuan untuk mengurangi tekanan terhadap hidupan liar diterapkan sesuai dengan hukum dan peraturan perburuan yang berlaku.

1.3.1 Seluruh partisipan mengetahui hukum dan peraturan menyangkut perburuan.

1.3.2 Keberadaan strategi asli bertujuan untuk melindungi jenis tertentu.

1.3.3 Metode anti perburuan liar dihargai dan diterapkan.

1.3.4 Peralatan dan metode berburu yang bersifat merusak dilarang.

1.3.5 Dilaksanakannya pengembangbiakan satwa domestik secara besar-besaran, yang memungkinkan pengurangan tekanan terhadap kehidupan liar.

4.2.4 Perburuan dengan perangkap dan pancing sangat berkurang selama musim kemarau.

Indonesia

\subsection{Perburuan dilakukan hanya terhadap satwa yang dapat} dikonsumsi secara lokal dan dianggap sebagai hama di ladang. 3.3.1 Musim berburu diatur.

\section{3.f. Intervensi produktif 4 (kayu)}

Pengelolaan dan ekstraksi kayu untuk keperluan domestik penting bagi seluruh masyarakat yang hidupnya tergantung pada hutan. Disamping itu pengelolaan dan ekstraksi kayu untuk keperluan pasar juga penting untuk kebanyakan orang. Isu ini mucul di dalam uji K\&l oleh masyarakat Brazil dan Indonesia. 
Brazil

\subsection{Pohon berkayu dipanen secara lestari.}

4.3.1 Tidak tampak gejala penurunan kerapatan populasi jenis kayu lokal.

\subsection{Ekspolitasi kayu dikerjakan berdasarkan azas kelestarian.}

5.2.2 Penerapan teknik berdampak rendah.

5.2.3 Penerapan perlakuan silvikultur khusus (pemotongan liana/ tumbuhan merambat, pembasmian tumbuhan pengganggu) sesuai dengan rencana operasional tahunan.

Indonesia

\subsection{Adanya integrasi sistematik hutan alam ke dalam pengelolaan sumberdaya masyarakat.}

6.1.1 Adanya pemanenan kayu secara lestari dibawah pengelolaan masyarakat.

6.1.1.1 Masyarakat mengetahui peraturan yang berlaku.

6.1.1.2 Ekstraksi kayu dipantau oleh petugas berwenang.

6.1.1.3 Adanya organisasi dibawah pengelolaan lokal yang mengkoordinir ekstraksi kayu.

6.1.1.4 Akses terhadap sumberdaya kayu secara adil diantara anggota masyarakat.

6.1.1.5 Adanya penanaman pohon kembali secara sistematik.

\section{3.g. Kesehatan hutan 1 (keanekaragaman hayati)}

Perlakukan terhadap keanekaragaman hayati oleh masyarakat cukup berbeda dibandingkan dengan apa yang dilakukan dengan pendekatan K\&l secara ilmiah ataupun komersial konvensional. Topik ini berkaitan dengan isu perburuan (lihat 3.e) dan HHBK lainnya (lihat 3.d). Sangat penting untuk menghargai dan mengenali kontribusi dari bidang agroforestry dan lahan tanaman lainnya terhadap keanekaragaman hayati. 
Brazil

1.2 Proses fragmentasi habitat tidak mengganggu pemeliharaan keanekaragaman hayati biologi pada tingkat lanskap hutan.

1.2.1 Proses fragmentasi dan konversi habitat primer harus dihentikan/dihambat untuk menghindari erosi keanekaragaman hayati dan musnahnya jenis lokal maupun regional.

2.1 Kelimpahan jenis satwa buru berukuran menengah dan besar dalam selang ukuran perburuan masyarakat terpenuhi jika dilihat dari sudut pandang ekologi dan sosial ekonomis.

2.1.2 Laju kelimpahan satwa buruan meningkat melebihi selang jarak yang kritis dari sumber tekanan perburuan (misalnya desa).

Kamerun

\subsection{Keanekaragaman hayati dikonservasi}

1.2.1 Organisasi spasial yang melindungi keanekaragaman hayati.

1.2.2 Pohon-pohon yang berguna namun semakin langka, dikenali dan dilindungi.

1.2.3 Penanaman jenis pohon asli dan berguna.

1.2.5 Satwa liar merasa aman dan nyaman.

1.3 Sistem pengelolaan hutan alami dan lahan pertanian bera secara berdampingan dan/atau ko-evolusi menjaga atau meningkatkan keanekaragaman hayati.

1.3.1 Diterapkannya tata guna lahan terpadu, yang terdiri dari keragaman sub-sistem yang menjamin keanekaragaman hayati secara keseluruhan relatif tinggi dibandingkan dengan subsistem manapun.

1.3.2 Selama penyiapan lahan pertanian, pohon yang bernilai tinggi dilindungi. 
Indonesia

1.2 Dampak terhadap keanekaragaman hayati ekosistem hutan diminimasi.

1.2.1 Jenis tumbuhan dan satwa yang terancam punah dilindungi.

1.2.2 Perburuan yang bersifat komersial diawasi.

1.2.3 Produksi yang lestari dari hasil hutan bukan kayu.

3.5 Keanekaragaman produk agroforestry berupa tembawang terpelihara.

3.5.1 Terpeliharanya keanekaragaman jenis dan genetik.

\section{3.h Kesehatan hutan 2 (struktur dan regenerasi)}

Struktur hutan, termasuk agroforestry, penting untuk memelihara lingkungan yang sesuai untuk mendukung keanekaragaman hayati (lihat 3.f) dan untuk mendukung fungsi ekosistem lainnya seperti kualitas air dan kesuburan tanah (lihat 3.b). Konsep stuktural juga memasukkan pola hutan primer dan sekunder (disoroti dalam perangkat di Brazil - yang juga berhubungan dengan seluruh mozaik lanskap, lihat 3.i); aspek struktur secara horizontal dan vertikal (disoroti dalam perangkat di Kamerun); dan kemampuan hutan untuk beregenerasi (ditekankan oleh tim Indonesia).

Brazil

1.1 Adanya hutan yang tidak terganggu secara struktural dan berkesinambungan yang memiliki kondisi ekologis sangat memuaskan untuk memelihara keanekaragaman hayati setempat dan pemanfaatan sumberdaya hutan secara lestari.

1.1.1 Proporsi hutan primer dan sekunder dalam PHM. 
Kamerun

\subsection{Terjaminnya regenerasi alami}

1.1.1 Distribusi horizontal bentuk tumbuhan yang berbeda memperlihatkan dinamika (keanekaragaman) struktur hutan.

1.1.1.1 Hutan stabil yang rapat (bentuk klimaks) dengan struktur yang serupa dengan hutan asli di wilayah bersangkutan.

1.1.1.2 Formasi hutan yang beragam (suksesi)- di zona yang disediakan untuk kegiatan pertanianberkembang selama masa bera.

1.1.2 Struktur vertikal hutan primer tidak terganggu.

1.1.2.1 Pohon dengan tinggi yang berbeda berperan dalam membentuk lapisan atau stratifikasi kanopi hutan (seperti: puncak-puncak pohon memiliki lapisan/ ketinggian yang berbeda-beda).

1.1.2.2 Diameter batang bervariasi.

1.1.2.3 Kanopi/tajuk pohon paling atas sambungmenyambung/kontinyu.

1.1.2.4 Lantai hutan kaya dengan anakan.

1.1.3 Distribusi dan frekuensi jenis sepadan dengan yang ada di hutan asli.

Indonesia

\subsection{Terjaminnya kemampuan ekosistem hutan untuk beregenerasi/ pulih kembali secara alami.}

1.3.1 Seluruh fasa pertumbuhan dari berbagai kelompok jenis terwakili. ${ }^{33}$

\footnotetext{
${ }^{33}$ Susunan kata dalam Indikator ini mempunyai arti bebas terbuka. Interpretasi yang mungkin lebih tepat adalah: Seluruh tahapan penting regenerasi jenis kelompok ekologi utama (seperti: guilds) terwakili di seluruh areal hutan yang dikelola oleh masyarakat.
} 
1.3.2 Habitat satwa dipelihara ${ }^{34}$ atau dijaga.

1.3.3 Kekayaan jenis dipelihara.

1.3.4 Struktur vegetasi dipelihara.

3.5.2 Struktur vegetasi tembawang menyerupai hutan alami.

\section{3.i Keanekaragaman bentang alam (fragmentasi dan mosaik)}

Di ketiga lokasi uji, isu konversi lahan hutan menjadi lahan lain serta kemungkinan resiko yang ditimbulkan akibat fragmentasi hutan dianggap penting. Lokasi di Brazil menempatkan isu integritas lanskap dibawah Kriteria yang mengakui pentingnya mozaik dari habitat yang berbeda di dalam lanskap, dan mengaku perlunya konversi menjadi lahan pertanian sebagai hal yang sensitif untuk seluruh mozaik. Perangkat K\&l Indonesia membahas isu ini dengan istilah khusus yang berhubungan dengan sistem kebun hutan tembawang setempat. Pendekatan yang digunakan di Kamerun memasukkan Indikator yang secara eksplisit menunjukkan bahwa proses penanganan masuknya jenis migran ke dalam suatu wilayah, sebagai tanda diawasinya konversi hutan.

Brazil

\subsection{Pemeliharaan suatu mozaik dalam habitat alami menjaga keberadaan jenis-jenis yang saling melengkapi secara alami.}

1.3.1 Diantara berbagai tipe habitat alami yang ada di dalam suatu wilayah, habitat yang paling jarang (ekstensifikasinya paling sedikit) dalam lanskap hutan, sangat dilindungi dari upaya konversi menjadi lahan pertanian.

\footnotetext{
${ }^{34}$ Bahan acuan dari Indikator ini (dan yang lainnya mengikuti) terhadap kualitas hutan agar "dipelihara", secara nyata mengandalkan pernyataan "keaslian" (sebagai pembanding) dapatlah diterima. Untuk mengungkapkannya secara lebih tepat, perlu dimasukkan bahan acuan sebagai berikut: "dibandingkan dengan keaslian yang dapat diterima" atau tingkat "regenerasi yang baik" terpelihara
} 
1.3.2 Hutan di sepanjang sungai dan sempadan anak sungai dilindungi dari tebang habis (clear felling) untuk mempertahankan fungsi hidrologis dan untuk konservasi keanekaragaman hayati. Ditegakkannya peraturan yang menetapkan minimum 50 m dari sempadan sungai dan anak sungai tidak boleh ditebang.

5.5.2 Pembukaan hutan alam untuk lahan pertanian dihindari.

5.5.3 Jumlah kepemilikan lahan pertanian tahunan tidak meningkat.

Kamerun

\subsection{Pembukaan lahan pertanian sebagian besar dibatasi hanya pada lahan bera dan hutan sekunder.}

2.1.1 Masa bera cukup panjang agar kesuburan tanah dapat pulih kembali.

\subsection{Laju konversi hutan alam rendah.}

2.2.1 Berkurangnya lahan yang ditutupi oleh hutan alam dalam kurun waktu tertentu.

2.2.2 Dibuatnya suatu ketentuan untuk menempatkan pemukim dan pendatang baru ke dalam desa tanpa menimbulkan tekanan pada hutan alam.

2.2.2.1 Pertimbangan akses yang dibuat oleh penguasa desa untuk secara langsung menempatkan pendatang baru dan imigran di dalam hutan alam sangat sedikit atau tidak ada.

2.2.2.2 Jumlah pendatang baru yang membuka kebun di dalam hutan alam diketahui dan dikontrol.

2.2.2.3 Kecenderungan migrasi. 
Indonesia

3.1 Hutan alam dipelihara untuk fungsi produksi dan nilai lingkungannya.

3.1.1 Terpeliharanya produktivitas hutan alam.

3.1.2 Dibatasinya konversi untuk ladang.

3.6 Konversi untuk tembawang dibatasi.

3.6.1 Konversi dapat dilakukan untuk pelestarian sumberdaya.

3.6.2 Konversi diikuti dengan pengembangan tembawang di daerah lain.

1.1.5 Pencegahan terhadap perubahan tutupan lahan secara dratis. 


\section{Prinsip 4. Lingkungan eksternal mendukung PHML}

Prinsip ini menangkap ide bahwa dalam upaya pengelolaan secara lestari, masyarakat didukung oleh badan-badan eksternal seperti pemerintah beserta lembaganya dan LSM. Di dalam penataan pengelolaan bersama (co-management), upaya untuk melibatkan kriteria eksplisit yang berhubungan dengan "kesehatan" hubungan kemitraan antara masyarakat dan mitra pengelolanya mungkin merupakan suatu gagasan yang baik. Di ketiga lokasi uji, co-management bukan merupakan isu, dan pada kenyataannya cakupan isu yang berhubungan dengan badan eksternal sangat bervariasi. Isu tersebut dapat dikelompokkan kedalam empat bagian, yaitu:

\section{a. Hubungan dengan pihak ketiga \\ b. Kebijakan dan kerangka hukum (tidak termasuk status kepemilikan) \\ c. Ekonomi \\ d. Pendidikan dan informasi}

\section{4.a Hubungan dengan pihak ketiga}

Hubungan dengan stakeholder lain sangat penting untuk kelestarian pengelolaan. Di ketiga lokasi uji, titik berat hubungan dengan pihak ketiga sangat berbeda (lihat Kotak 4). Tim di Brazil lebih banyak menangani hubungan dengan pihak-pihak yang mempekerjakan anggota masyarakat; tim di Kamerun menangani hubungan dengan pemerintah dan LSM; sedangkan tim di Indonesia hanya menyebutkan hubungan dengan masyarakat lainnya. Secara keseluruhan informasi ini menunjukkan diperlukannya komunikasi yang baik antara masyarakat dengan pihak ketiga. 
Kotak 4. Hubungan-hubungan dengan pihak ketiga: pengalaman dari tiga tempat uji CIFOR

\section{Desa Sao Pedro dan Canchoeira, Para, Brazil}

Pada dasawarsa yang lalu wilayah hutan yang cukup luas yang berdekatan dengan sungai Arapiuns dan anak sungainya dimana desa-desa tersebut berlokasi, mengalami ekploitasi secara besar-besaran oleh perusahaan penebangan hutan. Kegiatan dari salah satu perusahaan tersebut jelas-jelas mempengaruhi Sao Pedro dan sedikit berpengaruh terhadap Cachoeira de Maro. Penduduk di Sao Pedro mengalami pengalaman buruk dalam hal tawaran kesempatan kerja dari perusahaan tersebut, dan dalam hal penurunan stok kayu di lahan mereka. Informasi ini sampai ke masyarakat di daerah hulu (ke arah jalur lintas utama yang direncanakan oleh perusahaan) yang selanjtunya bersatu dengan Sao Pedro untuk menarik semua perusahaan kayu keluar dari wilayahnya. Persatuan pekerja pedesaan dan LSM lokal yang lainnya membantu beberapa masyarakat yang ada di sepanjang sungai Arapiuns, termasuk Sao Pedro dan Canchoiera de Maro, mengajukan usulan untuk membuat kawasan cadangan untuk ekstraksi yang dikukuhkan secara hukum.

\section{Desa Bedigong dan Darok, Kalimantan Barat, Indonesia}

Desa-desa tersebut ada diantara beberapa desa yang menjadi anggota organisasi kerjasama antar kelompok masyarakat yang dibuat atas bantuan Proyek Pengembangan Kehutanan Sosial, sebuah kerjasama antara Departemen Kehutanan dengan pemerintah Jerman. Kerjasama ini mengembangkan perusahaan kehutanan dalam skala kecil dan ingin menerapkan Rencana Pengelolaan Hutan untuk areal hutan alam yang berdekatan dengan Bedigong, milik Darok. Biaya dan keuntungan dari upaya tersebut akan dibagian diantara partisipan mulai dari seluruh anggota masyarakat. Pengelolaan kerjasama ini pada akhirnya akan menjadi tanggung jawab penuh semua anggota masyarakat.

\section{Desa Eyek II dan Akak/Bitetele, Endom, Kamerun}

Penduduk kedua desa tersebut termasuk dalam kelompok federasi desa SOLIDAM ('Solidarite pour development des villages d'Akak a Melan'). Berdiri pada tahun 1990, Solidam memiliki anggota kurang lebih 850 individu yang berasal dari 11 desa-desa di sekitar, yang mencakup wilayah kurang lebih berukuran 11 x $35 \mathrm{~km}$. Solidam memperoleh bantuan dari beberapa LSM Kamerun, dan baru-baru ini memperoleh dana dari program GIF World Bank, dan WWF-Kamerun untuk mengembangkan proyek lingkungan, pertanian, kesehatan dan peningkatan pendapatan. 
Brazil

6.5 Kondisi dan hak pekerja yang layak dan dipandang (paling tidak) hanya dalam hubungan pekerja di bidang agroforestry antara anggota masyarakat dan pelaku eksternal.

6.5.1 Pendapatan dan keuntungan yang layakjika dikaitkan dengan tugas yang dikerjakan.

6.5.2 Tidak terdapat upah di bawah standar dan eksploitasi pekerja anak dan wanita.

6.5.3 Kondisi pekerjaan memadai dan mematuhi peraturan yang ada.

6.5.4 Tidak ada perbudakan.

6.5.5 Hak-hak berorganisasi dijamin.

6.5.6 Hak negosiasi secara kolektif antar masyarakat, wakilwakilnya dan pelaku eksternal dijamin.

Kamerun

3.4 Penduduk desa berpartisipasi dengan stakeholder lain dalam upaya perlindungan sumberdaya kayu di dalam masyarakat.

3.4.1 Masyarakat bertindak aktif melindungi jenis pohon kayunya dari eksploitasi oleh orang luar yang mungkin, juga didukung oleh petugas kehutanan.

5.5.2 Pemerintah dan LSM membimbing masyarakat dalam pengelolaan hutan berkelanjutan.

7.1.3 Adanya struktur dialog dalam masyarakat untuk negosiasi/diskusi menyangkut isu pengelolaan hutan dengan petugas pemerintah dan LSM.

Indonesia

4.3 Terdapat konsensus hak kepemilikan antar masyarakat.

4.3.1 Terdapat mekanisme penyelesaian konflik di luar batasan masyarakat.

4.3.1.1 Kasus konflik menyangkut lahan diantara masyarakat.

4.3.1.2 Kasus-kasus penyelesaian konflik.

4.3.1.3 Konflik diselesaikan melalui mekanisme penyelesaian konflik. 


\section{4.b Kebijakan dan kerangka hukum (tidak termasuk status kepemilikan)}

Kebijakan dan kerangka hukum pemerintah yang suportif dapat memberikan kekuatan bagi pengelola hutan untuk berhadapan dengan pihak ketiga, dan memberikan bantuan praktis untuk menangani konflik yang sulit. Pengakuan hukum dalam pengelolaan oleh masyarakat dipandang penting dalam uji di Kamerun dan Brazil. Partisipasi dalam perencanaan pengembangan program dan kebijakan menjadi perhatian dalam uji di Indonesia dan Brazil. Isu ini berkaitan dengan otoritas masyarakat untuk mengelola (lihat 1.d), manajemen konflik (lihat 1.e) dan status kepemilikan lahan secara perorangan (lihat 2.d).

Brazil

\subsection{Masyarakat belajar tentang hak untuk berorganisasi politik dan sosial.}

6.2.2 Penerapan proses hukum dalam penyelesaian konflik tentang sumberdaya agroforestry melibatkan pelaku internal dan/atau eksternal (tetangga, perusahaan kayu dan masyarakat lain, pelanggan, dan lain-lain).

6.2.2.a Survei terhadap pencatatan resmi tentang konflik menyangkut penggunaan lahan dan kepemilikan, dan sumberdaya agroforestry, serta pemecahannya.

6.2.2.c Penduduk setempat diberi kompensasi atas kerusakan sumberdaya agroforestry yang disebabkan oleh pihak ketiga.

6.6.1.e Sejarah partisipasi masyarakat dalam menentukan kebijakan publik berkaitan dengan dampak lokal maupun nasional.

Kamerun

\subsection{Pengelolaan sumberdaya hutan sesuai dengan tujuan pemerintah di dalam pembangunan dan pengelolaan hutannya.}

5.5.1 Kemampuan sistem hukum untuk dapat menampung aspirasi masyarakat setempat dalam pengelolaan hutan. 
5.5.1.1 Isi peraturan dan kebijakan kehutanan.

5.5.1.2 Perubahan di dalam ilmu hukum.

7.1.2.1 Pengadilan hukum resmi mengakui keputusan yang dihasilkan dari sistem hukum tradisional.

Indonesia

\subsection{Rencana pemerintah dan program pembangunan didasarkan pada pertimbangan status kepemilikan lahan setempat dan sistem penggunaan lahan.}

4.2.1 Sistem penggunaan lahan setempat merupakan bagian dari beberapa program pembangunan.

4.2.1.1 Adanya partisipasi penuh masyarakat setempat dalam perencanaan dan implementasinya.

4.2.1.3 Kesetaraan "gender" dalam segala proses. ${ }^{35}$

4.2.1.4 Adanya partisipasi dalam mengambil keputusan untuk kerjasama yang menguntungkan.

4.2.1.5 Seluruh golongan masyarakat berpartisipasi dalam hal keuntungan.

\section{4.c Ekonomi}

Lingkungan ekonomi eksternal dimasukkan di tiga lokasi uji, terutama yang berkaitan dengan pasar yang umumnya digunakan untuk perdagangan hasil hutan yang dikelola oleh masyarakat. Isu ekonomi lainnya yang dibahas adalah subsidi, transportasi dan investasi prasarana (lihat 2.b).

Brazil

5.7.2 Pengetahuan mengenai pemasaran/perdagangan hasil hutan dan pertanian.

5.7.3 Keberadaan mekanisme masyarakat dalam hal komersialisasi produk.

\footnotetext{
${ }^{35}$ Ini merupakan hal yang tidak umum dalam mengekspresikan kepentingan persamaan gender (karena ini merupakan "persamaan" -berlawanan dengan kesetaraan, dan "seluruh" berlawanan dengan "jika memungkinkan"). Ekspresi-ekspresi yang lebih umum mengenai isu ini dinyatakan sebagai: "Laki-laki dan perempuan seluruhnya berpartisipasi dalam proses".... atau "Terdapat keseimbangan gender dalam partisipasi proses"....
} 
5.7.3.1 Prasarana dan transportasi dapat diakses oleh masyarakat (kapal, jalur, jalan, dan lain-lain).

5.7.3.2 Keberadaan "cantinas" yang dijalankan oleh masyarakat, yang menjual hasil "petani" hutan dan membeli input dalam jumlah besar untuk dijual kembali dengan atau mendekati harga modal/ biaya yang dikeluarkan.

5.7.4 Pengetahuan menyangkut biaya produksi (biaya penyusutan peralatan, investasi kembali, pemeliharaan).

6.7.3 Ketergantungan masyarakat pada subsidi eksternal yang diberikan oleh LSM, organisasi keagamaan dan/atau pemerintah.

Kamerun

5.2.1.2 Pengetahuan tentang nilai komersil sumberdaya hutan.

Indonesia

6.3.5 Adanya sistem pendukung pertanian.

6.3.5.1 Input pertanian tersedia.

6.3.5.2 Kredit pertanian tersedia.

6.3.5.3 Keberadaan pasar untuk karet.

3.4.1.1 Keberadaan pasar untuk produk tembawang.

\section{4.d Pendidikan dan informasi}

Di Indonesia, pendidikan dipandang penting dan dijelaskan secara penuh sebagai perangkat $\mathrm{K} \& l$. Di lokasi uji lain, pendidikan kurang diperhatikan. Isu ini berkaitan dengan kearifan dan ilmu pengetahuan (lihat 2.c). Sumber informasi seperti dokumen, peta dan data sensus secara teratur dijadikan acuan dalam Penguji. Ketersediaan informasi mungkin merupakan isu penting yang harus dipertimbangkan di dalam haknya masing-masing. Bagian penting lainnya yang ditemukan oleh tim Indonesia adalah dukungan "penyuluhan" dalam bentuk pelatihan dan bantuan dalam menerapkan sistem pengelolaan ladang. 
Brazil

5.1.2.2 Pemetaan "penggunaan lahan utama" dengan menggunakan peta dan citra satelit.

5.5.2.2 Pemetaan vegetasi penutup dengan tahun yang berbeda menggunakan citra satelit.

6.7.4.c Persentase anak usia sekolah yang mengikuti sekolah secara teratur.

Kamerun

5.5.2.3 Pengembangan program pendidikan yang layak.

Indonesia

7.1 Pendidikan formal dan non formal mendukung kelestarian hutan.

7.1.1 Akses umum ke semua tingkatan pendidikan formal.

7.1.2 Isi kurikulum lokal diarahkan pada pendidikan kesadaran lingkungan.

7.1.2.1 Pelajaran tentang lingkungan.

7.1.2.2 Pelajaran tentang sistem/penggunaan Iahan setempat.

6.3.4 Adanya pelatihan ${ }^{36}$ tentang pertanian menetap.

7.1.3.4 Pelatihan anggota masyarakat tentang masalah lingkungan.

7.1.3.5 Pelatihan tentang kegiatan untuk menghasilkan pendapatan.

7.1.3.6 Pertukaran informasi dengan sumber informasi di luar masyarakat.

6.2.4. Adanya kebijakan dan kegiatan untuk merasionalisasi sistem ladang.

6.2.4.1 Penggunaan pengetahuan lokal.

6.2.4.2 Mobilisasi pengetahuan ilmiah.

6.2.4.4 Percobaan lapangan.

${ }^{36}$ Beberapa perangkat $\mathrm{K} \& \mathrm{I}$ diterapkan untuk eksistensi pelatihan sebagai suatu indikator atau penguji, karena luasannya yang mana hanya merupakan suatu masukan. Dengan kata lain, keberadaan kursus pelatihan dapat atau tidak dapat secara nyata mengindikasikan kontribusi ke arah kelestarian- ini tergantung pada kualitas kursus, para partisipan-contoh: diperolehnya beberapa pilihan sebagai hasil kursus. Hal ini menunjukkan bahwa semakin akuratnya Indikator atau Penguji dapat menunjukkan dampak kursus pelatihan yang diberikan/ diterapkan tentang keahlian yang baru saja dipelajari, dan lain-lain. 


\section{Permohonan Tanggapan (Umpan Balik)}

Kami berharap agar pedoman ini memberikan titik awal yang sangat bermanfaat untuk mendapatkan pengalaman yang sukses dalam memantau PHM secara lestari. Kami melihat hal ini sebagai permulaan dan pekerjaan yang terus berkembang; jika Anda menggunakan pedoman ini, kami dengan senang hati akan menerima informasi tentang pengalaman, umpan balik dan saran-saran dari Anda sekalian.

Bill Ritchie dan Mandy Haggith dapat dihubungi di Worldforest.

Mail: 95 Achmelvich, Lochinver, Sutherland IV27 4JB, SCOTLAND Email: bill@worldforests.org

Cynthia McDougall (atau siapapun di CIFOR yang bekerja pada Program Local People, Devolution and Adaptive Co-Management) dapat dihubungi di alamat CIFOR melalui email: c.mcdougall@cgiar.org atau cifor@cgiar.org

Kami dapat juga dihubungi melalui surat di:

Local People, Devolution and Adaptive Co-Management Programme

The Center for International Forestry Research

P.O. Box 6596 JKPWB, Jakarta 10065, Indonesia

tel:+62 (251) 622622 fax:+62(251) 622100 


\section{Bahan Acuan (Referensi)}

Seluruh bahan acuan di bawah ini dapat diperoleh melalui pesanan kepada penerbit (beberapa diantaranya memerlukan biaya pengiriman). Alamat beberapa penerbit dicantumkan pada halaman terakhir pedoman ini. Beberapa bahan acuan yang disitir juga tersedia di "World Wibe Web (WWW)", ada beberapa yang mencantumkan alamat WWW (URL). Masih banyak buku, paper dalam jurnal dan laporan menyangkut pengelolaan hutan oleh masyarakat (beberapa diantaranya dijadikan acuan dalam laporan lengkap uji K\&l yang ditulis oleh Burford de Oliveira et al., 1999).

\section{Bahan acuan untuk Uji Lapangan K\&I PHM CIFOR (dasar dari pembuatan pedoman ini):}

Burford de Oliveira, N., Shiembo, P., Tiani, A. and Vabi, M. 1988. Developing and testing Criteria and Indicators for the sustainability of Community Managed Forests in the SOLIDAM zone, Central Province, Cameroon. CIFOR Draft Field Test Report.

Buford de Oliveira, N.B., Richie, B., McDougall, C., Hartanto, H. and Setyawati, T. 1999. Developing Criteria and Indicators of Community Managed Forests as assessment and learning tools: Objectives, methodologies and results. CIFOR.

Buford de Oliveira, N. 1999. Community participation in developing and applying Criteria and Indicators of sustainable and equitable forest management. CIFOR Project Report.

Mattos, M.M. with Buford de Oliveira, N., Silva, L., Peres, C. and Murrieta, R. Relatorio do testo do Brasil: Desenvolvendo e testando criterios e indicadores de sustentabilidade para manejo florestal comunitario. 1998. CIFOR Field Test Report. (In Portuguese only).

Maryani, R., Sunito, S., Hatta, G. and Buford de Oliveira, N. 1998. Developing Criteria and Indicators for Community Managed Forests-Indonesian test sites. CIFOR Field Test Report. 


\section{Bahan acuan untuk K\&l:}

CIFOR C\&I Team. 1999. The CIFOR Criteria and Indicators Toolbox Series. CIFOR, Bogor, Indonesia.

Seri ini ditujukan untuk K\&l hutan komersial, dan memuat perangkat sebagai berikut:

1. Guidelines for Developing, Testing and Selecting Criteria and Indicators for Sustainable Forest Management.

2. The CIFOR Criteria and Indicators Generic Template

3. CIMAT (Criteria and Indicators Modification and Adaptation Tool) (hanya di CDROM )

4. The CIFOR Criteria and Indicators Resource Book Database (hanya di CD ROM)

5. The BAG (Basic Assessment Guide for Human Well-being)

6. The Grab Bag: Supplementary Methods for Assessing Human Wellbeing

7. Scoring and Analysis Guide for Assessing Human Well-being

8. Who Count Most?Assessing Human well-being in Sustainable Forest Management

9. Guide for Applying Multi-Criteria Analysis to the Assessment of Criteria and Indicators)

Herweg, K., Steiner, K., Slaat, J. (eds.). 1998. Sustainable Land Management - Guidelines for Impact Monitoring (Workbook and Toolkit). Centre for Development and Environment, Berne, Switzerland.

Lammert van Bueren, E.M. and Blom, E. 1997. Hierarchical framework for the formulation of sustainable forest management standards. Principles, Criteria and Indoicators. The Tropenbos Foundation, Wageningen, the Netherlands.

Mendoza, G., and Macoun, P. with Prabhu, R., Sukadri, D., Purnomu, H. and Hartanto, H. 1999. Guidelines for applying multi-criteria analysis to the assessment of Criteria and Indicators. CIFOR C\&I Toolbox Series, Tool No.9. 
Prabhu, R., Colfer, C.J.P. and Dudley, R.G. 1999. Guidelines for developing, testing and selecting Criteria and Indicators for sustainable forest management. CIFOR C\&I Toolbox Series, Tool No.1.

Prabhu, R., Colfer, C.J.P., Venkateswarlu, P., Tan, L.C.m Soemadi, R. and Wollenberg, E. 1996. Testing Criteria and Indicators for the sustainable management of forests: Phase 1 Final Report. CIFOR.

Salim, A. and Colfer, C.J.P. with McDougall, C. 1999. Scoring and analysis guide for assessing human well-being. CIFOR C\&l Toolbox Series, Tool No.7.

Stevens, P. 1997. Measuring the sustainability of forest village ecosystem concepts and methodologies: A Turkish example. CSIRO, Australia.

Stork, N.E., Boyle, T.J.B., Dale, V., Eeley, H., Finegan, B., Lawes, M., Manokaran, N., Prabhu, R. and Soberon, J. 1997. Criteria and Indicators for assessing the sustainability of forest management: Conservation of biodiversity. CIFOR Working Paper 17.

\section{Lihat juga:}

"Forest Stewardship Council" webpage, khususnya bagian "Principles and Criteria of sustainable forest management (FSC standards)". http:// fscus.org/fscus2a12.html

Webpage CIFOR untuk Perangkat Kriteria dan Indikator (untuk hutan-hutan komersial) dan publikasi-publikasi lain:www.cifor.cgiar.org/acm/methods/ candi.html

\section{Bahan acuan untuk metode dan perangkat partisipatif:}

Brice, J.W. 1989. Community forestry: rapid appraisal of tree and land tenure. FAO Community Forestry Note 5.

Case, D'A.D. 1990. The Community's Toolbox: The idea, methods and tools for participatory assessment, monitoring and evaluation in community forestry. FAO Community Forestry Field Manual 2. 
Colfer, C.J.P. with Prabhu, R., Gunter, M., Mc.Dougall, C., Miyasaka-Porro, N. and Porro, R. 1999. Who counts most?Assessing human well-being in sustainable forest management. CIFOR C\&I Toolbox, Tool No.8.

CIFOR Methods Testing Team. 1999. The BAG: Basic Assessment Guide for human well-being. CIFOR C\&l Toolbox, Tool No.5.

Freudenberger, K.S. 1994. Tree and land tenure rapid appraisal tools. FAO Community Forestry Field Manual 4.

Thomson, J.T. and Freudenberger, K.S. 1997. Crafting institutional arrangements for community forestry. FAO Community Forestry Field Manual No. 7.

\section{Bahan acuan yang digunakan sebagai latar belakang PHM:}

Arnold, J.E.M. 1992. Community forestry: Ten years in review. FAO Community Forestry Note 7.

Arnold, J.E.M. 1998. Managing forests as common properti. FAO Forestry Paper 136.

Edmunds, D. and Wollenberg, E. Forthcoming. A Strategic Approach to Multistakeholder Negotiations. Paper accepted for publication in Development and Change.

Messerschmidt, D.A.et al. 1993. Common forest resource management: Annotated bibliography of Asia, Africa and Latin America. FAO Community Forestry Note 11.

Ostrom, E. 1999. Self-governance and forest resources. CIFOR Occasional Paper No. 20. Www.cgiar.org/CIFOR/publications/occpaper/occpaper20/ OP-20.pdf

Poffenberger, M. (ed.). 1998 onwards. Communities and forest management regional profile series. Working Group on Community Involvement in Forest Management (WG-CIFM).

Thomson, J.T. 1992. A framework for analyzing institutional incentives in community forestry. FAO Community Forestry Note 10. 
Verolme, H.J.J., and Moussa, J. (eds.). April 1999. Addressing the underlying causes of deforestation and forest degradation-case studies, analysis and policy recommendations. Biodiversity Action Network, Washington DC. www.bionet-us.org

Warner, K. 1999. Shifting cultivators: Local technical knowledge and natural resource management in the humid tropics. FAO Community Forestry Note 8. 


\section{Beberapa alamat penting yang berkaitan dengan PHM}

\section{PHM/pemantauan bahan acuan dan laporan}

Untuk laporan yang dipublikasikan oleh CIFOR, silakan hubungi:

CIFOR (Center for International Forestry Research)

P.O. Box 6596 JKPWB Jakarta 10065

Indonesia

Telepon:+62-251-622-622;Fax:+62-251-622-100

Email:cifor@cgiar.org: Http://www.cifor.cgiar.org

Untuk laporan yang dipublikasikan oleh FAO, silakan hubungi:

Forests, Trees and People Programme

Community Forestry Unit, Forestry and Planning Division

FAO (Food and Agriculture Organisation of the United Nations)

Viale delle Terme di Caracalla,

Rome 00100, Italy

Fax: (39-6)5705-5514

Email: ftpp@fao.org: Http://www.fao.org/waicent/faoinfo/forestry/fon/fonp/cfu/ default.htm

Untuk laporan yang dipublikasikan oleh WG-CIFM, silahkan hubungi:

Working Group on Community Involvement in Forest Management

The World Conservation Union - IUCN

Rue Mauverney 28

$\mathrm{CH}-1196$ Gland

Switzerland

Tel:+41-22-999-0001; Fax:+41-22-999-0025

Email: spr@hq.iucn.org 


\section{Organisasi yang terlibat dalam PHM/pemantauan}

\section{IDS}

Participation Group

Institute of Development Studies

University of Sussex, Brighton BN1 9RE, UK

Tel: +44 1273 606261; Fax: +44 1273621202

Email: participation@ids.ac.uk; Http://www.ids.ac.uk/ids/particip/infoexch.html

\section{IISD}

International Institute of Sustainable Development

161 Portage Avenue East, 6th Floor

Winnipeg, Manitoba, R3B OY4, Canada

Tel: +1 204-958-7700; Fax: +1 204-958-7710

Email: info@iisd.ca; Http://iisd.ca/

\section{RECOFTC}

The Regional Community Forestry Training Center

Kasetsart University, PO Box 1111

Bangkok 10903, Thailand

Tel: +66-2-940-5700; Fax: +66-2-561-4880

Email: ftcsss@nontri.ku.ac.th; Http://recoftc.org/

\section{The Forest Stewardship Council}

PO Box 10

Waterbury, Vermont 05676, USA

Tel: +1-802-244-6257; Fax: +1-802-244-6258

E-mail: info@fscus.org; Http://fscus.org/fscus2.html

\section{The Tropenbos Foundation}

Lawickse Allee 11

P.O. Box 232

6700 AE Wageningen

The Netherlands

Tel: +31 317 426262; Fax: +31317423024

Email: tropenbos@iac.agro.nl; Http://www.bib.wau.nl/tropbos/ 


\section{Lampiran 1.}

\section{Sinopsis permasalahan dan perbandingan antara lokasi uji K\&I PHM CIFOR}

Sinopsis ini didasarkan pada uji lapangan CIFOR, dan oleh karenanya mengandalkan pada keaslian ("ilmiah" yang lebih konvensional) dari empat pengelompokan K\&l - Ekologi, Pengelolaan Hutan, Sosial dan Partisipasi Masyarakat.

\section{K\&l Ekologi}

K\&l mengenai integritas ekosistem, keanekaragaman hayati, pengelolaan daerah aliran sungai, struktur hutan dan regenerasi alam dikembangkan oleh seluruh tim penguji di bidang ekologi. Tim ekologi Indonesia memberikan penekanan pada pertimbangan aspek tanah dan perlindungan jenis langka. Tim ekologi Kamerun lebih menitikberatkan pada strategi berburu dan pengaruh sistem pertanian (termasuk metode pengelolaan hama) terhadap kelestarian hutan. Sebagai tambahan, perangkat juga memasukkan sejumlah K\&l untuk mengevaluasi praktek pemancingan lokal, dimana di lokasi uji di Kamerun, terdapat hubungan yang nyata secara ekonomis khususnya bagi wanita.

Sebagian besar K\&l untuk praktek memancing, dapat ditemukan pada perangkat pengelolaan hutan dan ekologi di Brazil. Perburuan dibahas secara lebih terperinci dalam perangkat Brazil, termasuk pula sebagian besar K\&l untuk mengamati pola perkembangan fragmentasi hutan, kualitas air dan peran konservasi hutan cadangan. K\&l Brazil dan Kamerun melakukan pendekatan penilaian terhadap perburuan secara berbeda; Brazil menekankan pada jumlah sedangkan Kamerun pada metode dan proses.

Sebab dan kejadian kebakaran hutan dijelaskan dengan lebih terperinci oleh tim ekologi Brazil dan oleh perangkat pengelolaan hutan di Indonesia dan Brazil. K\&l yang kompleks untuk penilaian metode pemanenan

${ }^{37}$ Bagian ini disarikan langsung dari Burford de Oliveira (1999) 
dan pengolahan HHBK lokal muncul dalam sub-perangkat ekologi dan pengelolaan hutan masyarakat Kamerun dan Brazil, dan dalam subperangkat aspek pengelolaan di Indonesia.

\section{K\&l pengelolaan hutan}

K\&I strategi pemanenan hasil yang lestari terdapat di seluruh perangkat aspek pengelolaan. Bahan acuan yang lebih eksplisit untuk menyesuaikan metoda pengelolaan dengan kapasitas sumberdayanya muncul di perangkat pengelolaan Brazil dan Indonesia - pada kasus di Brazil penyesuaian diamati menggunakan isu zonasi. $K \& l$ pengelolaan di Indonesia menyoroti teknologi hutan yang dipakai secara lokal, yaitu topik yang dilihat dari sudut komplementer perangkat aspek sosial masyarakat Indonesia. Bahan acuan teknologi dalam hal ini sangat lemah jika dibandingkan dengan perangkat di negara lain. Perangkat pengelolaan di Indonesia juga memberikan $K \& l$ yang lebih rinci menyangkut agroforestry. Ini disebabkan pentingnya keberadaan kebun Tembawang dan karet yang secara ekonomis telah dikenal luas pada masyarakat yang ada di lokasi uji di Indonesia.

Perangkat pengelolaan di Kamerun dan Brazil menitikberatkan pada penilaian metode pemanenan/ekstraksi yang merusak. Penyusunan perangkat pengelolaan untuk Kamerun dilakukan tersendiri karena K\&l yang rumit menyangkut integrasi kegiatan ekonomi yang tergantung pada hutan. Perangkat ini juga termasuk K\&l tentang kecenderungan demografis dan konversi hutan untuk pertanian, sama halnya dengan sejumlah perangkat untuk menilai peranan sistem pertanian terhadap konservasi hutan dan keanekaragaman hayati. Isu ini dibahas dari sudut yang sedikit berbeda dalam perangkat ekologi di Kamerun. K\&l pengelolaan hutan Indonesia tidak mengacu pada konversi hutan alam, tetapi diterangkan dalam konversi agroforestry ke pertanian. Kedua perangkat pengelolaan di Kamerun dan Brazil memberikan berbagai macam K\&l menyangkut waktu dan frekuensi intervensi hutan dan kegiatan pemanenan. 
Beberapa K\&l tentang pemasaran hasil hutan dan kerjasama petani hutan muncul di perangkat pengelolaan Brazil, seperti juga K\&l yang kompleks untuk penilaian kegiatan pemantauan hutan dan patroli oleh masyarakat. Isu yang terakhir disebutkan juga sebagian dibahas dalam beberapa $\mathrm{K} \& \mathrm{l}$ pengelolaan di Kamerun menyangkut resistensi masyarakat terhadap adanya pembagian sumberdaya hutan mereka oleh kelompok eksternal yang berkepentingan.

Dibandingkan dengan perangkat pengelolaan lainnya, masyarakat Brazil memberikan penekanan khusus dalam hal evaluasi pengelolaan kayu, termasuk K\&l pada masalah: siklus penebangan, arah rebah penebangan, ketinggian batang pohon, perlakuan pembebasan dan jaringan jalan hutan. Penekanan dilakukan pada evaluasi strategi pengelolaan dari sisi implikasi keuangan. Hal ini berbeda dengan beberapa $\mathrm{K} \& \mathrm{l}$ pengelolaan di Indonesia, dimana prioritas diberikan secara lebih eksplisit terhadap pertimbangan ekologi penilaian ekstraksi kayu. Perbandingan perangkat pengelolaan yang digunakan di Brazil dan Kamerun menghasilkan dikotomi lainnya dimana Brazil memfokuskan secara tidak langsung pada integrasi pasar, sedangkan Kamerun menitik beratkan pada stabilitas yang lebih tertutup, sistem ekonomi tradisional yang lebih berdasar pada transaksi timbal balik.

\section{K\&l Sosial}

Seluruh perangkat sosial berisi $K \& l$ tentang terjaminnya status kepemilikan lahan dan hukum adat, akses terhadap sumberdaya hutan, proses pengambilan keputusan, mekanisme penyelesaian konflik, dan K\&l yang ditujukan langsung maupun tidak langsung terhadap pola distribusi biaya-manfaat (cost-benefit) pengelolaan hutan. Perangkat K\&l sosial di Brazil, dan Indonesia secara eksplisit berhubungan dengan sumberdaya milik umum. Seluruh perangkat K\&l sosial berdasar pada signifikansi sistem pengetahuan lokal terhadap metode pengelolaan hutan yang dilakukan saat ini, termasuk sejumlah bahan acuan reproduksi dan perkembangan ilmu pengetahuan. Kebanyakan K\&l 
sosial di Indonesia untuk aspek pengetahuan lebih berhubungan dengan kuantitas dan isi pendidikan formal. Hal ini bertujuan untuk mengamati/ mempelajari bagaimana pendidikan formal menunjang reproduksi dan perkembangan sistem pengetahuan tradisional - serangkaian penelitian tampaknya sudah mendesak untuk segera dilakukan, karena semakin banyak praktek tradisional yang dilupakan dan relevansi pengetahuan tradisional seringkali dibatasi pada introduksi ide dan teknologi baru.

K\&l sosial di Brazil mengenai hak pekerja, kondisi bekerja dan hubungan merupakan pelengkap yang baik bagi $\mathrm{K} \& \mathrm{l}$ pengelolaan integrasi pasar di Brazil. Perangkat tersebut meliput sejarah penempatan buruh dan hubungannya dengan pelaku dari luar, peraturan perburuhan dan perbudakan. Hal tersebut tidak disebut secara langsung dalam perangkat $K \& l$ lain. $K \& l$ sosial di Brazil mengenai organisasi politik masyarakat juga memperlihatkan fokus yang tidak ditemukan di perangkat lainnya. Diantara K\&l sosial Brazil, ditemukan bahan acuan yang secara eksplisit ketergantungan terhadap hutan, termasuk model ketergantungan secara langsung dan tidak langsung, dan K\&l yang berkaitan dengan persoalan ketergantungan terhadap hutan yang beragam, seperti keluarga berencana, pola konsumsi makanan, perlindungan tempat-tempat warisan budaya dan transmisi pengetahuan tradisional. Beberapa isu ini berhubungan dengan perangkat yang digunakan oleh negara lainnya, tetapi pada konteks K\&l yang berbeda yang terlihat dalam penempatan isu dalam kerangka kerja hirarkis.

K\&l sosial Kamerun lebih menekankan pada kesesuaian peraturan dan kebijakan pemerintah dengan strategi dan kontrol pengelolaan lokal. Beberapa perangkat $\mathrm{K} \&$ sosial Indonesia dan Brazil, mencakup hal serupa seperti kebijakan pemerintah yang berhubungan dengan bentuk penggunaan lahan setempat dan partisipasi masyarakat yang didukung oleh program pemerintah. 


\section{K\&l partisipasi masyarakat}

K\&I Indonesia memuat K\&l yang paling terperinci dan eksplisit untuk menilai partisipasi anggota masyarakat dalam urusan masyarakat dan politik, serta inisiatif pemerintah dalam pembangunan masyarakat. Namun demikian, beberapa pernyataan yang berhubungan dengan tindakan kolektif dan kerjasama antara anggota masyarakat terdapat pada perangkat sosial dan pengelolaan hutan Kamerun. K\&l sosial Brazil memasukkan pula beberapa $K \& l$ partisipasi masyarakat dalam perencanaan dan pemantauan terhadap intervensi pengelolaan. Perangkat di ketiga negara melibatkan beberapa $K \& I$ yang mengacu pada perbedaan kelompok, seperti pengelompokan berdasarkan pada minat, umur, atau jenis kelamin. Sebagai perbandingan, hanya sedikit yang menyebutkan satu kepentingan tertentu atau kelompok minoritas, dan hampir semua yang melakukannya memusatkan perhatian pada partisipasi perempuan dalam debat. Hal ini menimbulkan beberapa kekuatiran berkaitan dengan kemampuan perangkat untuk menangkap minat dan kebutuhan khusus kelompok minoritas, kelompok yang tertindas, atau kelompok yang sangat sedikit terwakili di dalam masyarakat. 


\section{Lampiran 2.}

\section{Perangkat dasar dan pedoman yang digunakan oleh tim penguji K\&I PHM}

Perangkat dasar dan pedoman yang digunakan oleh tim penguji PHM adalah sebagai berikut:

Biodiversity Support Program. 1993. Guiding principles and recommendations for African integrated biodiversity conservation and sustainable development. In: Biodiversity Support Program, African biodiversity: Foundation for the future. Profesional Printing, Beltsville, Maryland.

CIFOR. 1997. Possible source themes for Criteria and Indicators for Community Managed Forests. Unpublished.

FAO. 1995. Indicators of sustainability. In: Resource management for upland areas in Southeast Asia.

Forest Stewardship Council. 1996. Principles and Criteria for forest management.

Lammerts van Bueren, E. and Blom, E. 1997. Hierarchical framework for formulation of sustainable forest management standards. The Tropenbos Foumdation, Wageningen, The Netherlands.

Lembaga Ekolabel Indonesia (LEI). The Criteria and Indicators for sustainable natural forest management on Forest Management Unit level. LEI webpage at http://www.iscom.com/-ekolabel.

Pierce, A. 1996. Issues pertaining to the certification of non-timber forest productys. A Forest Stewardship Council Discussion Paper, 1 May. Forest Stewardship Council.

Prabhu, R. et al. 1996. Sets of principles, Criteria, Indicators and Verifiers resulting from tests conducted in Ivory Coast and Brazil. In: Testing Criteria and Indicators for sustainable management of forests: Phase 1 final report. CIFOR.

Prescott-Allen, R. 1996. Barometer of sustainability. In: IUCN, An approach to assessing progress towards sustainability. Tool and Training Materials Series 2-8317-0342-5. 
Smart Wood. 1995. Standards for non-timber forest products certification: The case of Brazil nuts (Bertholletia excelsa h.b.k.) and rubber (Hevea braziliensis), Version \# 2.0, 16 th August Richmond, Vermont.

Stevens, P. 1997. Measuring the sustainability of forest village ecosystem concepts and methodologies: A Turkish example.CSIRO, Australia.

Stortenbeker, C.et al. 1997. First draft of process of revision of DDB Principles, Criteria and some Indicators. Tropenbos, The Netherlands.

Zimmermann, R. 1992. Provisional assessment guidelines used in connection with smallholder eco-timber projects in Papua New Guinea (NovemberDecember). Smart Wood, Richmond, Vermont.

Zweede, J., Kressin, J., Mesquita, R., Silva, J.N.M., Viana, V.M. and Colfer, C. 1995. Final Report-Test Brazil October 22 - November 21, 1995. CIFOR Project on testing Criteria and Indicators for the sustainable management of forests. CIFOR, Bogor, Indonesia. 
Sistem pengelolaan hutan oleh masyarakat melibatkan sejumlah besar unsur kebijaksanaan, ilmu pengetahuan, dan ketrampilan praktis serta pengelolaan yang diperlukan untuk kelestarian sumber daya hutan secara global. Sistem ini, bagaimanapun juga, menghadapi ancaman dalam berbagai bentuk, termasuk cepatnya perubahan di dalam konteks politik, sosial ekonomi, dan biofisik. Upaya menerapkan pengelolaan hutan dengan cukup cepat dan efektif untuk memenuhi perubahan tersebut dirasakan mendesak dan merupakan tantangan besar.

Pedoman ini menampilkan Kriteria dan Indikator pengelolaan hutan oleh masyarakat secara lestari (K\&I PHML) sebagai alat bantu komunikasi dan belajar yang berpotensi yang dapat membantu dalam menghadapi tantangan tersebut. Pedoman ini banyak mengambil bahan penelitian kerjasama yang dilakukan CIFOR tentang K\&I PHM di Brazil, Indonesia, dan Kamerun agar dapat mengajukan pendekatan tahap demi tahap yang fleksibel untuk mengembangkan dan menerapkan sistem pemantauan hutan baik yang dilakukan secara sendiri maupun kolaboratif. Pedoman ini juga menampilkan beberapa contoh $K \& \mid$ yang dikembangkan oleh masyarakat di ke tiga negara tersebut. Pendekatan ini ditujukan bagi masyarakat dan mitra kerjanya dalam pengelolaan hutan, seperti LSM, pemerintah, atau proyek pengembangan yang sedang mencari strategi dalam rangka memperbaiki kesejahteraan manusia dan kelestarian hutan melalui pengambilan keputusan, kerjasama dan proses belajar yang lebih efektif dalam pengelolaan hutan setempat.

ISBN 979-8764-43-9

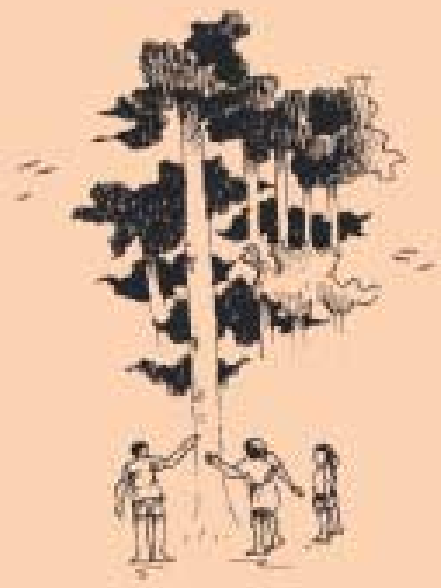

